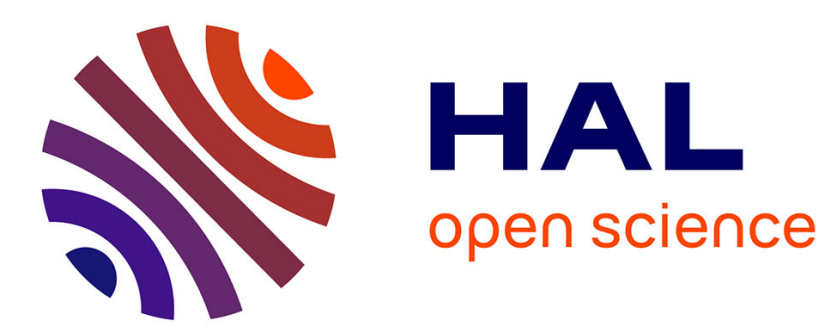

\title{
Benzyl $\beta$-malolactonate polymers: a long story with recent advances
}

Cédric C. Jaffredo, Sophie M. Guillaume

\section{To cite this version:}

Cédric C. Jaffredo, Sophie M. Guillaume. Benzyl $\beta$-malolactonate polymers: a long story with recent advances. Polymer Chemistry, 2014, 5, pp.4168-4194. 10.1039/c4py00170b . hal-01077996

\section{HAL Id: hal-01077996 \\ https://hal-univ-rennes1.archives-ouvertes.fr/hal-01077996}

Submitted on 27 Oct 2014

HAL is a multi-disciplinary open access archive for the deposit and dissemination of scientific research documents, whether they are published or not. The documents may come from teaching and research institutions in France or abroad, or from public or private research centers.
L'archive ouverte pluridisciplinaire HAL, est destinée au dépôt et à la diffusion de documents scientifiques de niveau recherche, publiés ou non, émanant des établissements d'enseignement et de recherche français ou étrangers, des laboratoires publics ou privés. 
Benzyl $\beta$-Malolactonate Polymers: a Long Story with Recent Advances

Cédric G. Jaffredo and Sophie M. Guillaume*

Institut des Sciences Chimiques de Rennes, UMR 6226 CNRS - Université de Rennes 1,

Campus de Beaulieu, F-35042 Rennes Cedex, France

*Corresponding author: sophie.guillaume@ univ-rennes1.fr 


\section{Table of Content}

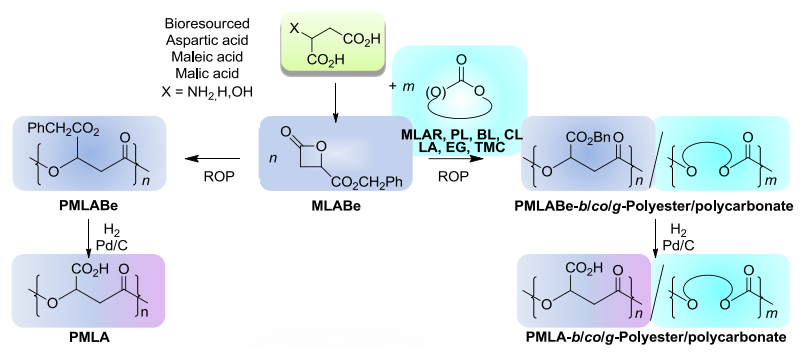

\section{Abstract}

Poly ( $\beta$-benzyl malolactonate) (PMLABe) is an aliphatic renewable, biocompatible, biodegradable, hydrophobic polyester of the poly(hydroxyalkanoate) (PHA) family. Along with the hydrophilic parent poly( $\beta$-malic acid) (PMLA), PMLABe and PMLA have been studied as materials for biomedical applications. Herein, advances on the synthesis of benzyl $\beta$ malolactonate (MLABe) and the related alkyl $\beta$-malolactonates (MLARs), PMLABe homopolymers and copolymers, are reviewed. Focus is placed on the ring-opening polymerization (ROP) of MLABe and on copolymers of MLABe, with relevant data on the performances of the initiating systems and on the PMLABes molecular characteristics, along with detailed mechanistic insights, being reported.

\section{Keywords}

Benzyl malolactonate, Poly(benzyl malolactonate), Poly(malic acid), Monomer and (co)polymers synthesis, Ring-opening polymerization 


\section{List of abbreviations}

\begin{tabular}{|c|c|}
\hline $18-C-6$ & 18-crown-6 \\
\hline AIBN & azobisisobutyronitrile \\
\hline BDI & $\begin{array}{l}\text { (E)- } N \text {-((Z)-4-(2,6-diisopropylphenylamino)pent-3-en-2-ylidene)-2,6- } \\
\text { diisopropylamine }\end{array}$ \\
\hline BEMP & 2-tert-butylimino-2-diethylamino-1,3-dimethylperhydro-1,3,2diazaphosphorine \\
\hline BL & $\beta$-butyrolactone \\
\hline $\mathrm{Bn}$ & benzyl $\left(-\mathrm{CH}_{2} \mathrm{Ph}\right)$ \\
\hline $\mathrm{CL}$ & $\varepsilon$-caprolactone \\
\hline $\mathrm{CMC}$ & critical micelle concentration \\
\hline DB18-C-6 & dibenzo-18-crown-6 \\
\hline DBU & 1,8-diazabicyclo[5.4.0]-undec-7-ene \\
\hline DCC & dicyclohexylcarbodiimide \\
\hline DIAD & diisopropyl azodicarboxylate \\
\hline diHLA & dihexyl-substituted lactide \\
\hline$\bigoplus_{\mathrm{M}}$ & $M_{\mathrm{w}} / M_{\mathrm{n}}=$ molar mass distribution \\
\hline DMAP & 4-dimethylaminopyridine \\
\hline DSC & differential scanning calorimetry \\
\hline EAO & ethyl aluminoxane \\
\hline$e e$ & enantiomeric excess \\
\hline equiv. & equivalent \\
\hline FA & folate \\
\hline FTIR & Fourier-transform infrared \\
\hline GRGDS & peptide H-Gly-Arg-Gly-Asp-Ser-OH \\
\hline HPLC & high-performance liquid chromatography \\
\hline IBAO & isobutyl aluminoxane \\
\hline INEPT & insensitive nuclei enhanced by polarization transfer \\
\hline KHDD & potassium 11-hydroxydodecanoate \\
\hline LA & lactide \\
\hline MALDI & matrix-assisted laser desorption/ionisation \\
\hline MAO & methyl aluminoxane \\
\hline MeMLABu & butyl 3-methyl $\beta$-malolactonate \\
\hline $\mathrm{Me}_{2} \mathrm{MLABe}$ & dimethyl benzyl $\beta$-malolactonate \\
\hline mHLA & monohexyl-substituted lactide \\
\hline MLAAll & allyl $\beta$-malolactonate \\
\hline MLABe & benzyl $\beta$-malolactonate \\
\hline MLABP & benzyloxypropyl $\beta$-malolactonate \\
\hline MLACho & cholesteryloxycarbonyl $\beta$-malolactonate \\
\hline MLAEAd & ethyladamantyl $\beta$-malolactonate \\
\hline MLAHe & hethyl $\beta$-malolactonate \\
\hline MLALac & $\omega$-methoxycarbonyloligolactyl $\beta$-malolactonate \\
\hline MLAMe & methyl $\beta$-malolactonate \\
\hline MLANAd & butyladamantanamide $\beta$-malolactonate \\
\hline MLAR & alkyl $\beta$-malolactonate \\
\hline$M_{\mathrm{n}}$ & number-average molar mass \\
\hline
\end{tabular}




\begin{tabular}{|c|c|}
\hline$M_{\mathrm{n}, \mathrm{NMR}}$ & molar mass measured by NMR \\
\hline$M_{\mathrm{p}}$ & molar mass measured at the top of the elution peak \\
\hline MPEG & methoxy- poly(ethylene glycol) \\
\hline Ms & mesyl/ methanesulphonyl $\left(-\mathrm{SO}_{2} \mathrm{CH}_{3}\right)$ \\
\hline MS & mass spectrometry \\
\hline NHC & $N$-heterocyclic carbene \\
\hline NMR & nuclear magnetic resonance \\
\hline PCL & poly(caprolactone) \\
\hline PEG & poly(ethylene glycol) \\
\hline PEO & poly(ethylene oxide) \\
\hline PHA & poly(hydroxyalkanoate) \\
\hline PHB (P(BL)) & poly(3-hydroxybutyrate) \\
\hline PHEMA & poly(2-hydroxyethyl methacrylate) \\
\hline PL & $\beta$-propiolactone \\
\hline PLA & poly(lactic acid) \\
\hline PMLA & $\operatorname{poly}($ malic acid $)$ \\
\hline PMLABe & poly(benzyl $\beta$-malolactonate) \\
\hline PS & poly(styrene) \\
\hline rac & racemic \\
\hline ROP & ring-opening polymerization \\
\hline SEC & size exclusion chromatography \\
\hline SIMS & secondary ion mass spectrometry \\
\hline $\mathrm{S}_{\mathrm{N}} 1$ & nucleophilic substitution of the first order \\
\hline $\mathrm{S}_{\mathrm{N}} 2$ & nucleophilic substitution of the second order \\
\hline TBD & 1,5,7-triazabicyclo[4.4.0]dec-5-ene \\
\hline$T_{\mathrm{c}}$ & crystallization temperature \\
\hline$T_{\mathrm{d}}$ & degradation temperature \\
\hline TEABz & tetraethylammonium benzoate \\
\hline TOF & turn over frequency (activity) \\
\hline TFA & trifluoroacetic acetate \\
\hline TFAA & trifluoroacetic anhydride \\
\hline$T_{\mathrm{g}}$ & glass transition temperature \\
\hline THF & tetrahydrofurane \\
\hline$T_{\mathrm{m}}$ & melting temperature \\
\hline TMABz & tetramethylammonium benzoate \\
\hline TOF & turnover frequency \\
\hline ToF & time of flight \\
\hline TON & turnover number \\
\hline TPP & tetraphenylporphyrin \\
\hline XPS & $\mathrm{X}$-ray photoelectron spectroscopy \\
\hline
\end{tabular}




\section{Biographies}

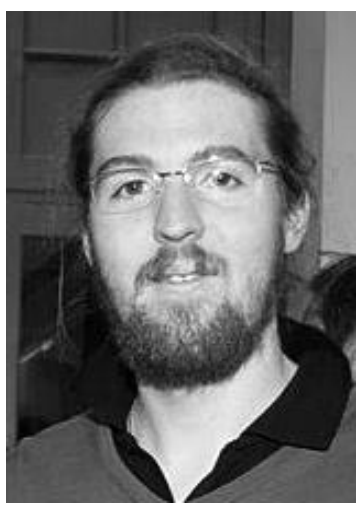

Cédric G. Jaffredo received his MSc from the University of Nantes in 2011, where he worked on supramolecular edifices for photosynthesis mimicking, with Dr. F. Odobel. He performed his master's thesis in the team of Prof. N. C. O. Tomkinson at the Cardiff University working on peroxide catalysts for dihydroxylation and allylic alcohol formation from alkene. He then started his Ph.D. under the supervision of Prof. J.F. Carpentier and Dr. S. M. Guillaume at the ISCR - University of Rennes. His work is mainly focused on (non)organometallic catalytic systems for ring-opening polymerization toward the synthesis of biobased and biodegradable (co)poly(hydroxyalkanoate)s.

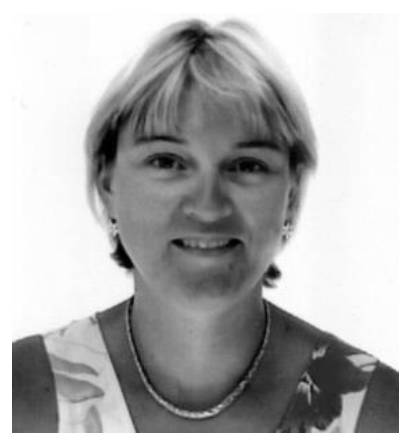

Sophie Guillaume completed her Ph.D. at Syracuse University, N.Y., USA prior to her postdoctoral research at the CEA-Saclay, France. She then joined the CNRS in 1994 working on f-element chemistry. In 2000 , she became interested in polymer chemistry, joining the Laboratory of Chemistry of Organic Polymers (LCPO) in Bordeaux, and recently the Institute of Chemical Sciences in Rennes (ISCR) where she holds a CNRS Directeur de Recherche position. Her research is mainly focused on the development of green strategies towards bio-based polymers, biocompatible and (bio)degradable polymers (polyesters, polycarbonates, polyurethanes, and polyolefins) at the interplay between fundamental and industrial outcomes. 


\section{Introduction}

Poly(hydroxyalkanoates) (PHA)s are a class of aliphatic thermoplastic polyesters which have attracted considerable attention over the last decades. Owing to their renewability, biocompatibility and biodegradability, they display a wide array of valuable uses ranging from single-use bulk, commodity plastics to specialized biomedical and pharmaceutical applications. In particular, PHAs have been developed as components of medical devices, engineered tissues, medical therapies, and especially of drug-delivery systems. PHA-based biomaterials aim at various outcomes in tissue (bone, nerve, cartilage) repair and regeneration such as coatings, wound dressings, sutures, patches, scaffolds, conduits, cardiovascular stents, grafts or valves, and other temporary or long-term implants. There are a number of reviews on PHAs dealing with their occurrence, their microbial synthesis as well as with their potential in medical applications. ${ }^{1-10}$ However, these essentially focus on the ubiquitous member of this family, namely poly(3-hydroxybutyrate) (PHB), a naturally and synthetically occurring polyester, and its PHA-based copolymers (Scheme 1). The major weaknesses of these PHAs which often impede their direct use lie in their hydrophobicity and in some physical limitations. Introduction into PHAs of various groups providing hydrophilicity has thus appeared as a valuable strategy to enlarge their field of applications. In this regard, poly(benzyl $\beta$-malolactonate) (PMLABe), a hydrophobic PHA, has gained interest over the past two decades. Indeed, PMLABe gives access to poly(malic acid) (PMLA), its water soluble congener, thereby enabling the design of amphiphilic PHA-based architectures (Scheme 1). Although PMLABe and PMLA have been reported as early as the late 1970 s, ${ }^{11}$ overviews on their synthesis and applications remain limited. ${ }^{12-17}$ 
Scheme 1. Structure of $\beta$-butyrolactone (BL), benzyl $\beta$-malolactonate (MLABe), of their corresponding polymers, poly(3-hydroxybutyrate) (PHB, i.e. poly( $\beta$-butyrolactone), P(BL)), poly(benzyl $\beta$-malolactonate) (PMLABe), respectively, and of poly(malic acid) (PMLA) obtained upon hydrogenolysis of PMLABe<smiles>CC1CC(=O)O1</smiles>

MLABe

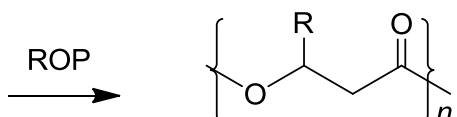

$\mathrm{R}=\mathrm{CH}_{3}, \mathrm{PHB}$

$\mathrm{R}=\mathrm{CO}_{2} \mathrm{CH}_{2} \mathrm{Ph}$, PMLABe
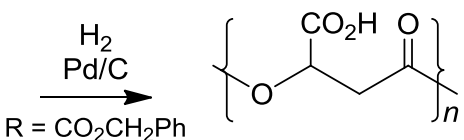

PMLA

Poly ( $\beta$-malic acid) (PMLA), which is naturally found in apples and in grapes, is a biocompatible, non-toxic, non-immunogenic and water soluble polyester, having the significant advantage of being metabolized into malic acid, an intermediate in the mammalian tricarboxylic acid cycle (also known as the citric acid cycle, the Krebs cycle, or the SzentGyörgyi-Krebs cycle), and completely biodegraded into carbon dioxide and water. ${ }^{13}$ Also, PMLA features reactive carboxylic acid pendant groups along the polymer backbone that can further serve as anchoring sites for biologically active molecules of interest such as drugs, or targeting and auxiliary modules. ${ }^{14,18,19}$ In this regard, PMLA is much more valuable than the widely studied, commercially available, hydrophilic and biocompatible poly(ethylene glycol) (PEG), since it provides more drug-attachment sites (one per each monomeric repeating unit) than PEG which has only two available positions, one at each polymer chain terminus. PMLA has thus instigated many studies for its potential applications as a drug or other functional moieties carrier, or part of a prodrug, especially as it can be produced from the non-toxic malic acid, a constituent of the citric acid cycle. ${ }^{16,20}$ Although a natural malic acid polymer was first isolated more than forty years ago, it was not characterized at that time with respect to its exact constitution. ${ }^{21-23}$ Based on high resolution ${ }^{1} \mathrm{H}$ and ${ }^{13} \mathrm{C}$ NMR investigations, Guérin and co- 
workers evidenced in the early 90's that natural PMLA isolated from Physarum polycephalum - a myxomycete for which it acts as a coordinator during DNA replication - belonged to the family of poly(3-hydroxyacid) aliphatic polyesters. ${ }^{24}$ More recently, Tandon and co-workers have studied the structural and spectral characteristics of PMLA from FTIR and Raman spectroscopies further supported by quantum chemistry insights. ${ }^{25}$ Actually, PMLA was synthetically prepared prior to being discovered in nature. ${ }^{11}$ PMLA can be artificially produced, similarly to $\mathrm{PHB},{ }^{1-10}$ by different microorganisms. In particular, the biological fermentation of PMLA was recently achieved using agricultural biomass substrates such as the yeast-like fungus Aureobasidium pullulans. After the optimization of culture conditions, this microbe afforded the highest PMLA concentration $\left(87.6\right.$ g. $\left.\mathrm{L}^{-1}\right){ }^{26}$ Also, PMLA with $M_{\mathrm{n}}=50-100$ $\mathrm{kg} \cdot \mathrm{mol}^{-1}$ and $\bigoplus_{\mathrm{M}}=M_{\mathrm{w}} / M_{\mathrm{n}}=1.3$, was secreted in significant amounts $(20 \mathrm{~g}$ PMLA from $20 \mathrm{~L}$ culture broth) and eventually enzymatically cleaved to L-malate by a hydrolase from plasmodia of Physarum Polycephalum. ${ }^{13,27}$ Several other productive bacteria derived from the slime mold such as Aureobasidium sp., Penicillium Cyclopium, Physarum Polycephalum, Cladosporium Cladosporioides, Corollospora Fusca or Aspergillus Flavus have been successfully identified. ${ }^{21-23,26-44}$ Whereas bio-fermentation is currently the main method to produce PMLA, the availability and reproducibility (homogeneity) of the biosource is still an issue. The control of the molar mass as well as high $M_{\mathrm{n}}$ values remain difficult to achieve, the productivity is still low, and the procedure is lengthy. Therefore, chemical routes towards PMLA have been sought. PMLA was thus synthesized by the one step simple polycondensation reaction from the corresponding malic acid. ${ }^{45-51}$ The optimized experimental conditions required the use of tin(II) chloride as catalyst and $45 \mathrm{~h}$ of reaction at $110{ }^{\circ} \mathrm{C}$. Besides the limitations inherent to the polycondensation route (exact stoichiometry required, high operating temperature and continuous removal of the low molar mass by-product (e.g. water)), this approach essentially gave oligomers with a molar mass $M_{\mathrm{n}}$ of $5300 \mathrm{~g} \cdot \mathrm{mol}^{-1}$ at best, essentially resulting from the 
presence of three reactive functionalities on malic acid. ${ }^{45}$ Although this molar mass value is within the range desirable for some medical applications, it limits other opportunities such as industrial ones. Nowadays, PLMA is thus best prepared by benzyl-deprotection of PMLABe upon hydrogenolysis under mild operating conditions, a procedure which selectively cleaves the benzylic ester groups without altering the aliphatic polyester backbone (Scheme 1).

Poly(benzyl $\beta$-malolactonate) (PMLABe), unlike PHB and PMLA which can be produced either naturally from bacteria or synthetically, is most commonly obtained through chemical synthesis. Indeed, while PMLA can be produced by different enzymes (yet most often only as oligomers), ${ }^{26-43}$ examples on the enzymatic polymerization of MLABe remain comparatively rare (Table 1). ${ }^{52,53}$ There have been just a few reports by Matsumura and coworkers on the lipase-catalyzed ROP of MLABe ${ }^{54-57}$. Although MLABe was polymerized by the Porcine Pancreatic, Novozyme 435 or Candida Cylindracea lipases at $60{ }^{\circ} \mathrm{C}$, the reaction times were quite long (1-7 days) and the molar mass values of the PMLABe obtained remained lower than ca. $M_{\mathrm{n}}=5100 \mathrm{~g} \cdot \mathrm{mol}^{-1} .56,57$ A high molar mass PMLABe $\left(M_{\mathrm{n}}=20100 \mathrm{~g} \cdot \mathrm{mol}^{-1}\right)$ was recovered only when Candida Cylindracea was complemented with $\beta$-propiolactone (PL, $17 \mathrm{~mol} \%) .{ }^{54}$

Table 1. PMLABe synthesized by enzymatic ROP of MLABe: operating conditions and polymers molecular characteristics.

\begin{tabular}{|c|c|c|c|c|}
\hline Enzyme & $\begin{array}{c}\text { Conditions } \\
\text { (Solvent, reaction } \\
\text { temperature, reaction } \\
\text { time) }\end{array}$ & $\begin{array}{c}M_{\mathrm{w}} \text { or } M_{\mathrm{n}} \\
\left(\mathrm{g} \cdot \mathrm{mol}^{-1}\right) \\
\text { (SEC solvent, } \\
\text { temperature, } \\
\text { standards) }\end{array}$ & $\boldsymbol{Ð}_{\mathbf{M}}$ & Ref. \\
\hline Porcine pancreatic lipase & $\begin{array}{l}\text { heptane, isooctane, bulk, } \\
60^{\circ} \mathrm{C}, 3 \mathrm{~d}\end{array}$ & $\begin{array}{c}M_{\mathrm{n}} 3600-4000 \\
\left(\mathrm{CHCl}_{3},-, \mathrm{PS}\right)\end{array}$ & $1.4-2.0$ & 56,57 \\
\hline Novozyme lipase & $\begin{array}{c}\text { heptane, isooctane, bulk, } \\
60^{\circ} \mathrm{C}, 3 \mathrm{~d}\end{array}$ & $\begin{array}{c}M_{\mathrm{n}} 3000-5100 \\
\left(\mathrm{CHCl}_{3},-, \mathrm{PS}\right)\end{array}$ & $1.3-1.9$ & 56,57 \\
\hline $\begin{array}{l}\text { Candida cylindracea lipase } \\
\text { (with PL or BL as additive) }\end{array}$ & $-, 40-60{ }^{\circ} \mathrm{C}, 1-7 \mathrm{~d}$ & $\begin{array}{c}M_{\mathrm{n}} 3900-20100 \\
\left(\mathrm{CHCl}_{3},-, \mathrm{PS}\right)\end{array}$ & $1.1-1.4$ & 54 \\
\hline
\end{tabular}

-: not reported 
Besides, the preparation of PMLABe by polycondensation has, to our knowledge, not been reported. Thus, PMLABe (similarly to PHB) is nowadays, and most efficiently, synthesized by ring-opening polymerization (ROP) of the corresponding four-membered ring $\beta$-substituted $\beta$-lactone, namely benzyl $\beta$-malolactonate (4-benzyloxycarbonyl-2-oxetanone, MLABe) (or $\beta$-butyrolactone (BL)), for which the driving force is the relief of the ring-strain (Scheme 1). ${ }^{15,16,58-60}$ It is indeed the pioneering work by Vert and Lenz in 1979, enabling the successful preparation of MLABe via its anionic ROP, that opened the route to the synthesis of PMLABe (and consequently to PMLA). ${ }^{11}$ Subsequently, PMLABe has been mainly synthesized by purely ionic ROP mediated by cationic or anionic initiators. This latter strategy afforded PMLABe with molar masses up to $M_{\mathrm{n}} 130000$ g.mol ${ }^{-1} 61$ depending of the purity of the monomer- and with large dispersities due to different side reactions. More recently, the pseudo-anionic coordination-insertion and nucleophilic ROPs have emerged as a promising route towards the synthesis of well-defined PMLABes, through efficient, controlled and living polymerizations mediated by metallic or organic initiating systems, respectively. Both solution and solvent-free (i.e. bulk) procedures are effective and other operating conditions (reaction temperature, reaction time, stoichiometry, etc...) are milder and less stringent than other approaches, thus making ROP a competitive strategy. The initial limitations of the ROP approach, inherent to the required purification steps of the monomer and also preventing access to high molar mass PMLABe, ${ }^{62}$ are no longer an issue since polymers (as well as copolymers) are easily isolated from novel ROP pathways upon selective precipitation. Subsequently, PMLABe copolymers have also emerged from ROP routes, thus reviving the overall interest for this PHA.

The present review aims at first reporting on the diverse synthetic routes for the preparation of the MLABe monomer. The different initiators/catalysts that have been investigated for the ROP of MLABe and its subsequent copolymerization with other cyclic ester 
monomers are next surveyed. Special emphasis is given to the recent advances in the controlled and living coordination-insertion and nucleophilic ROPs allowing the preparation of original MLABe copolymers.

\section{Synthesis of benzyl $\beta$-malolactonate (MLABe)}

One possible approach towards the synthesis of $\beta$-lactones is through the selective alternating copolymerization of carbon monoxide and epoxides. ${ }^{63-65}$ However, although the corresponding MLABe-epoxide is known, ${ }^{66,67}$ MLABe has not been prepared according to this procedure.

Alternatively, MLABe proved to be a bio-based monomer since it can be produced from renewable biomass resources. In particular, routes have been established from either aspartic acid or malic acid, two "green" acids, sugar-derived building block members of the "top 10" or latter "top 10-revisited" value added chemicals from carbohydrate-based biorefineries, established by the US Department of Energy. ${ }^{68,69}$ The synthesis of MLABe can thus be achieved from a 1,2-diacid through a number of different routes involving multiple steps (Scheme 2). The present section focuses on the specific methods established for the synthesis of MLABe.

\section{Scheme 2. Representative syntheses of MLABe from bio-resourced 1,2-diacids}

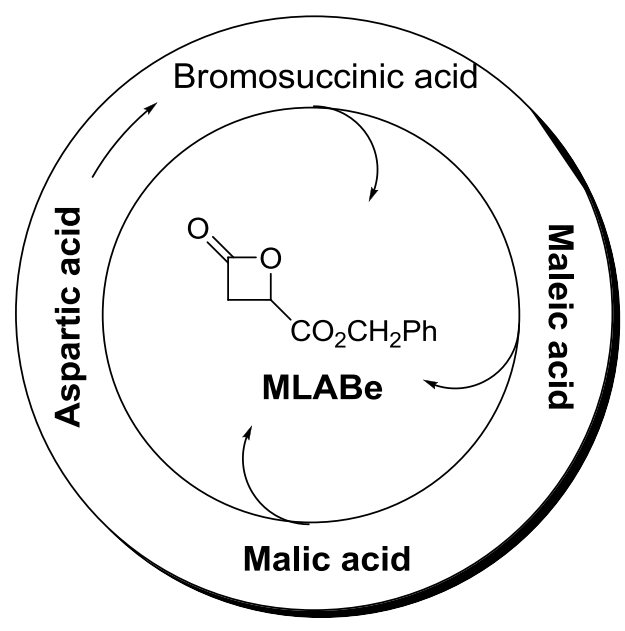




\subsection{Synthesis of MLABe from aspartic acid or bromosuccinic acid}

The first synthetic pathway to MLABe was established in $1979,{ }^{11}$ and later described in $1981^{70}$ by Vert and Lenz, using racemic-bromosuccinic acid (rac-bromosuccinic acid) as starting reagent (Scheme 3). Bromosuccinic acid was actually first prepared from biosourced aspartic acid upon bromination (Scheme 3). ${ }^{71}$ Also, the preparation of both enantiopure $(R)$ - and $(S)$-MLABe $(e e=96 \%)$ from the corresponding enantiomeric aspartic acid opened the possibility to access to optically active PLMABe and PMLA, as first established by Guérin and co-workers. ${ }^{71}$ The diacid was first reacted with acetyl chloride $(\mathrm{AcCl})$ to lead to bromosuccinic anhydride. Later, this step was further improved by the use of trifluoroacetic anhydride (TFAA) which then enabled to reach higher yields, (90-100\% vs 70-75\% with AcCl). ${ }^{62}$ This cyclic anhydride was next opened with benzyl alcohol, thereby affording a mixture of two monobenzyl bromosuccinates. The four-membered MLABe ring was finally formed by internal nucleophilic substitution, from only the major $\beta$-bromoester with the benzyl substituent acting as a protecting group. This ring-closing reaction was initially catalyzed by

silver nitrate salts. ${ }^{70}$ Later, sodium carbonate ${ }^{72}$ and more recently, sodium hydroxide ${ }^{62}$ have replaced this silver catalyst thereby avoiding the side reactions caused by small residues of silver and occurring during the purification of the monomer. In the case of $\mathrm{NaOH}$, the authors noticed the importance to fix the $\mathrm{pH}$ in the range of 7.2-7.8. Racemic-MLABe (rac-MLABe) was thus prepared in four steps from racemic-aspartic acid with an overall yield of $11 \%$ (Scheme 3). Typically, ca. $12 \mathrm{~g}$ of rac-MLABe were obtained starting from $100 \mathrm{~g}$ of racemicbromosuccinic acid or from $125 \mathrm{~g}$ of racemic-aspartic acid. ${ }^{62}$

Scheme 3. Synthesis of rac-MLABe from racemic-bromosuccinic acid or racemic-aspartic acid $^{11,62,70-72}$ 


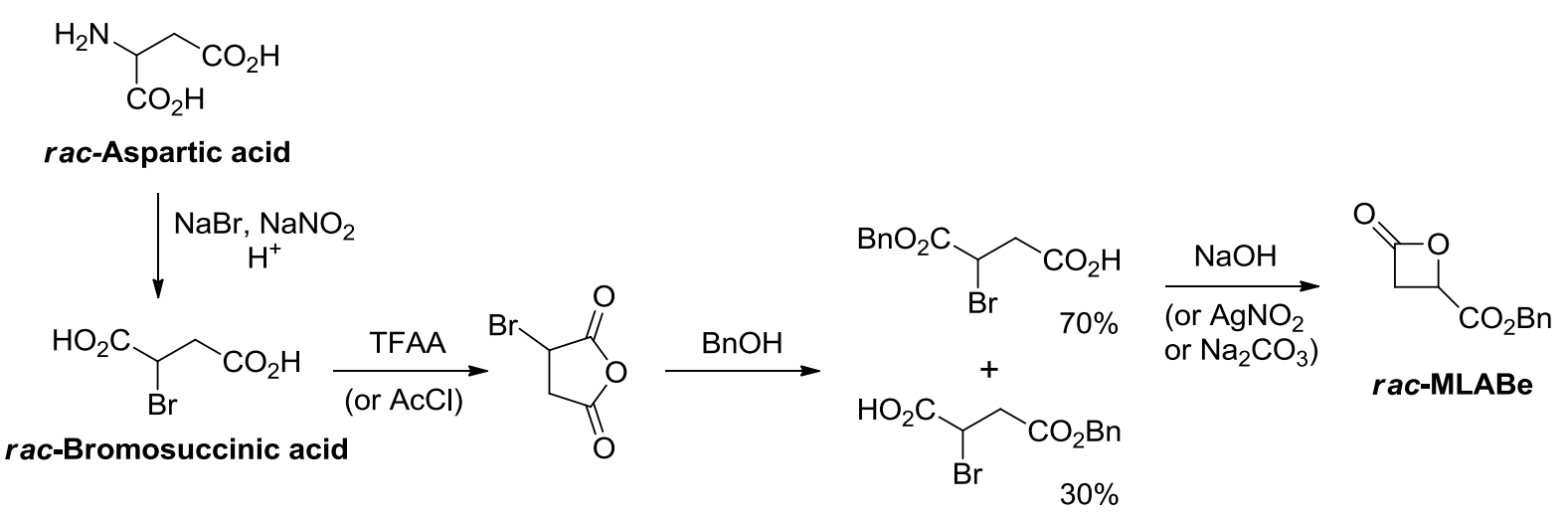

\subsection{Synthesis of MLABe from maleic acid}

The problem inherent to this first strategy is the formation of a mixture of the two monoesters. To avoid this difficulty, Johns and co-workers explored the synthesis of MLABe from maleic acid (Scheme 4). ${ }^{72}$ As described above from bromosuccinic acid, the unsaturated cyclic anhydride was first formed from the reaction of maleic acid with TFAA. This five-membered ring was then opened by transesterification using $\mathrm{BnOH}$ thereby affording a unique unsaturated monoester. A hydrobromination step of this latter alkene gave the single $\beta$-bromoester, which was then converted to MLABe using sodium carbonate. However, the authors reported the formation of benzyl bromide as a by-product during the purification step, and difficulties to purify the resulting $\beta$-bromoester. Rac-MLABe was thus prepared in four steps from maleic acid with an overall yield of $3 \%$ (Scheme 4$){ }^{72}$

\section{Scheme 4. Synthesis of $r a c$-MLABe from maleic acid ${ }^{72}$}




$$
\mathrm{CO}_{2} \mathrm{H}
$$

Maleic acid

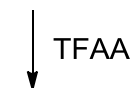

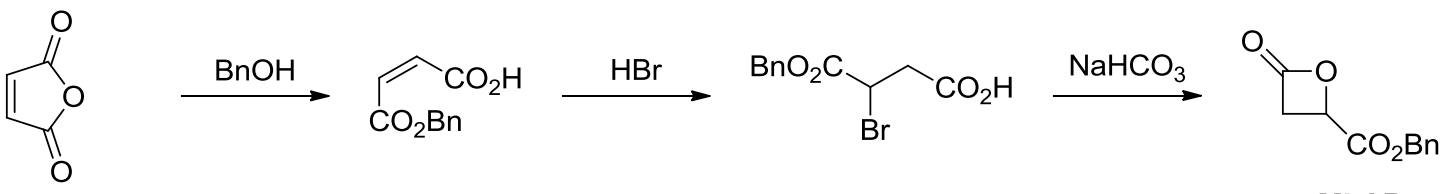

\subsection{Synthesis of MLABe from malic acid}

In addition, strategies for the synthesis of MLABe from malic acid have been explored. The first approach was briefly reported by Lenz and Guérin (Scheme 5) ${ }^{73}$ Malic acid was selectively protected, by an $O, O$-acetal on the 1,2-hydroxy-acid position. Although the conditions of this protection were not detailed, it should by easily carried out using the corresponding aldehyde or geminal diol. ${ }^{74,75}$ The second step involved the reaction of the carboxylic acid group using a (unspecified) thiol affording, after deprotection a hydroxy-thioester. Finally, an intramolecular lactonization reaction was performed in the presence of a mercuric acid catalyst.

Scheme 5. Synthesis of $r a c$-MLABe from maleic acid via a thioester ${ }^{73}$

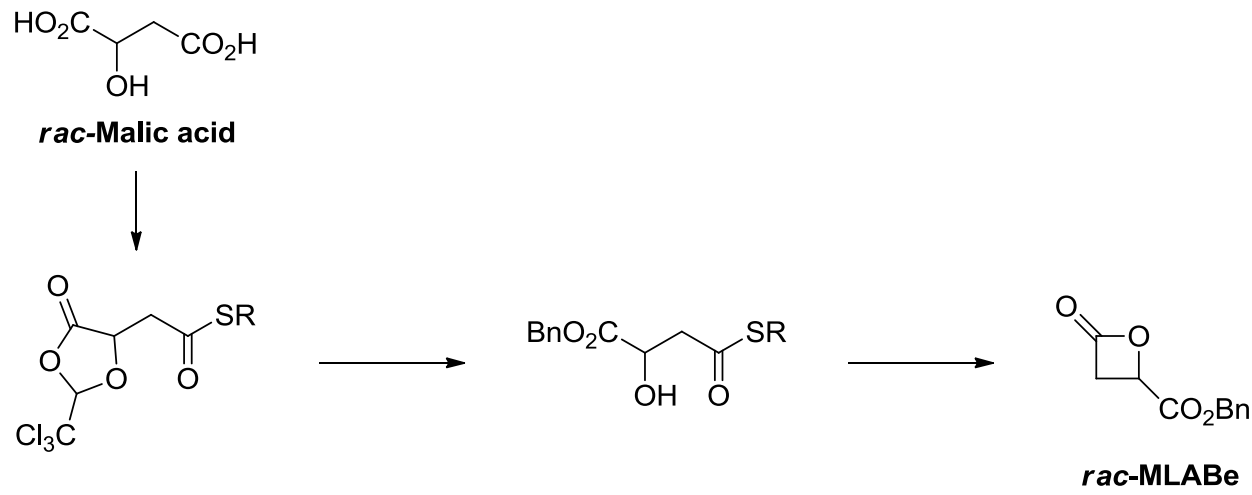

Arnold and Lenz have developed another strategy using mesyl chloride ( $\mathrm{MsCl})$ as a leaving group (Scheme 6). ${ }^{76}$ In this approach, malic acid was first reacted with $\mathrm{BnOH}$ so as to 
protect the two carboxylic functions. $\mathrm{MsCl}$ was next introduced to protect the alcohol function and activate it into the-OMs group. Subsequent deprotection of the benzyl ester functions was achieved with $\mathrm{HBr}$. Indeed, the sulfur atom of the -OMs group being poisonous to palladium, hydrogenolysis catalyzed by $\mathrm{Pd} / \mathrm{C}$ could not be carried out. The diacid thus obtained was thus next transformed into the corresponding anhydride by TFAA, and this anhydride was ultimately reacted with benzyl alcohol to afford a mixture of monobenzyl esters. As described previously, only the $\beta$-mesylate ester was ring-closed into MLABe using sodium hydroxide $(\mathrm{pH}=7.2-7.8)$ (Scheme 5). ${ }^{62}$ This six-step long and tedious route afforded MLABe with an overall yield of $5 \%$, similarly to the aspartic approach. Typically, $8 \mathrm{~g}$ of MLABe were obtained starting from $100 \mathrm{~g}$ of malic acid. ${ }^{76}$

\section{Scheme 6. Synthesis of $r a c$-MLABe from malic acid via mesyl chloride ${ }^{76}$}<smiles>CC(Br)(Br)C(C)(C)OC(=O)C(O)CC(=O)O</smiles><smiles>O=C(CC(O)C(=O)OBr)O[Na]</smiles>
$\mathrm{OH}$

$\mathrm{O}$<smiles>O=C1CC(C(=O)Br)O1</smiles>
rac-MLABe<smiles>Cl[Mg]Cl</smiles>
$\mathrm{NaOH}$<smiles>COC(CC(=O)OCc1ccccc1)C(=O)OCc1ccccc1</smiles><smiles></smiles><smiles>COC(CC(=O)O)C(=O)O</smiles><smiles>COC(CC(=O)O)CC(=O)OCC(=O)O</smiles>
TFAA<smiles>[B]O</smiles><smiles>COC1CC(=O)OC1=O</smiles>

Finally, the latest and simplest strategy was established by Guérin and co-workers from malic acid (Scheme 7). ${ }^{77}$ Direct reaction of malic acid with TFAA gave a succinate substituted 
by a -OTFA ester $(\mathrm{TFA}=$ trifluoroacetic acetate), which was next ring-opened by $\mathrm{BnOH}$ to yield to the unique $\alpha$-hydroxybenzyl ester. MLABe was then prepared from this monoester by a coupling reaction in the presence of diisopropyl azodicarboxylate (DIAD) and triphenylphosphine $\left(\mathrm{PPh}_{3}\right)$. Rac-MLABe was thus quite easily prepared in up to $1.2 \mathrm{~g}$ starting from $10 \mathrm{~g}$ malic acid ( $8 \%$ of overall yield) within a couple-to-a few days. ${ }^{77}$

Also, this latter strategy applied to L-(S)-malic acid afforded $(R)$-MLABe as a unique enantiomer with high enantiomeric excess $(e e>98 \%) .{ }^{77}$

\section{Scheme 7. Synthesis of rac-MLABe from malic acid via-OTFA succinate ${ }^{77}$}

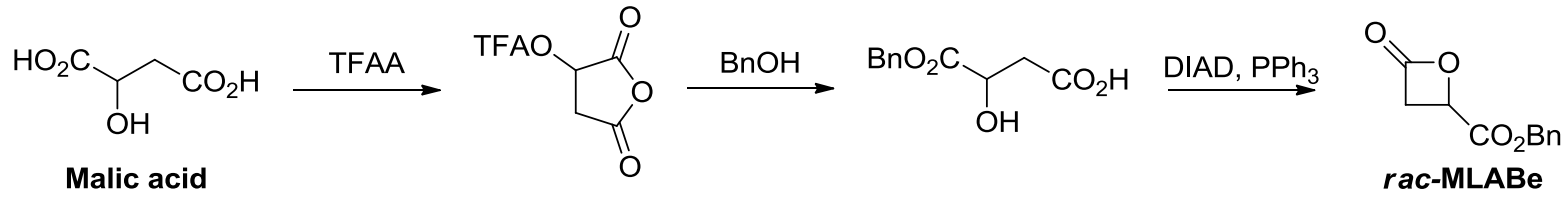

Note that the approach based on the [2+2] cycloaddition between a ketene and the benzylglycolate in presence of triethylamine was attempted by Guérin and co-workers. ${ }^{78}$ Unfortunately, this route did not allow the preparation of MLABe, whereas it successfully enabled the preparation of other alkyl $\beta$-malolactonates (MLAR; with $\mathrm{R}=\mathrm{Me}$, Et, ${ }^{i} \mathrm{Pr},{ }^{n} \mathrm{Bu}$ or $\mathrm{CH}_{2} \mathrm{CCl}_{3}$; Table 2).

Nowadays, the synthesis of MLABe is most efficiently carried out from aspartic acid, as referenced in the state of the art. ${ }^{79-83}$ All the approaches developed from aspartic acid or malic acid, also give access to other MLARs upon exchanging $\mathrm{BnOH}$ with other alcohol derivatives. The various MLARs that have thus been prepared are gathered in Table 2, for further reference when describing their copolymerization with MLABe (vide infra). Other works referring to these MLARs synthesized upon cycloaddition of ketene with alkyl glyoxylates are also included. 
Table 2. Alkyl $\beta$-malolactonates (MLARs) and the corresponding 1,2-diacid and alcohol (or ketene) from which they have been synthesized

\begin{tabular}{|c|c|c|c|}
\hline Alcohol & $\begin{array}{l}\text { Diacid } \\
\text { reagent }\end{array}$ & MLAR & Ref. \\
\hline Methanol & $\begin{array}{l}\text { Malic acid, } \\
(S) \text {-malic acid }\end{array}$ & $\begin{array}{c}\text { Methyl } \beta \text {-malolactonate } \\
\text { MLAMe }\end{array}$ & 77,78 \\
\hline Ethanol & $\begin{array}{l}\text { Malic acid, } \\
(S) \text {-malic acid }\end{array}$ & Ethyl $\beta$-malolactonate & 77,78 \\
\hline $\begin{array}{c}\text { Isopropanol } \\
\text { (isopropyl glyoxylate) }\end{array}$ & $\begin{array}{l}\text { (S)-Malic acid } \\
\text { (Ketene) }\end{array}$ & Isoproyl $\beta$-malolactonate & 77,78 \\
\hline (n-Butyl glyoxylate) & (Ketene) & $\begin{array}{c}n \text {-Butyl } \beta \text {-malolactonate } \\
\text { MLABu }\end{array}$ & 78 \\
\hline 1-Hexanol & Aspartic acid & $\begin{array}{c}\text { Hexyl } \beta \text {-malolactonate } \\
\text { MLAHe } \\
-1\end{array}$ & $62,84,85$ \\
\hline $\begin{array}{l}\text { 1-Octanol } \\
\text { 1-Decanol } \\
\text { 1-Dodecanol } \\
\text { 1-Tetradecanol }\end{array}$ & Aspartic acid & Octyl-,decyl-,dodecyl-,tetradecyl- & 86 \\
\hline Benzyl alcohol & $\begin{array}{l}\text { Aspartic acid, } \\
(S) \text { - and }(R)- \\
\text { aspartic acid, } \\
\text { malic acid, }\end{array}$ & $\begin{array}{c}\text { Benzyl } \beta \text {-malolactonate } \\
\text { MLABe }\end{array}$ & 76,77 \\
\hline
\end{tabular}




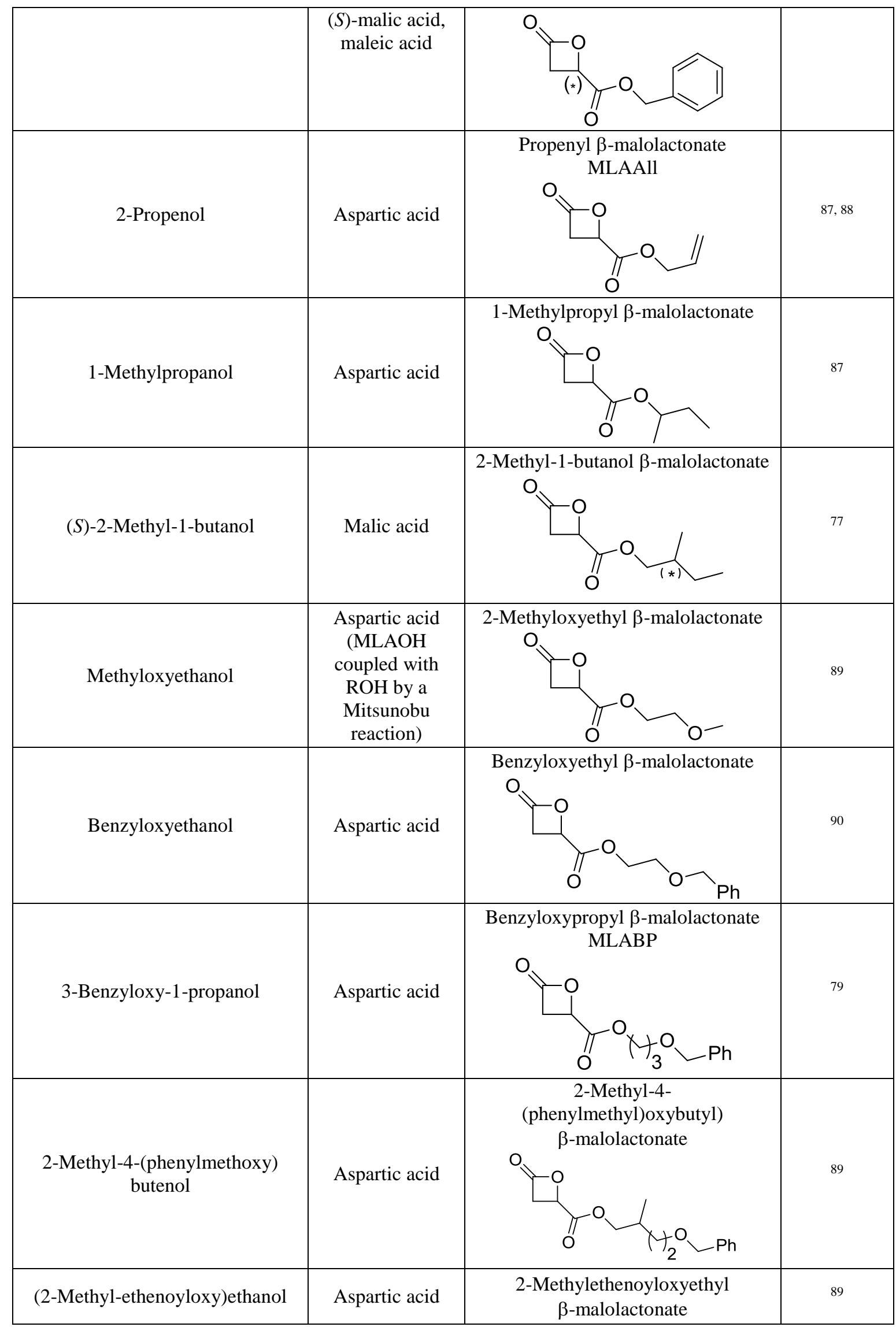




\begin{tabular}{|c|c|c|c|}
\hline & & OO & \\
\hline 3-Methyl-2-butenol & Aspartic acid & 3-Methyl-2-buten-1-yl & 89 \\
\hline 3-Methyl-3-butenol & Aspartic acid & $\begin{array}{l}\text { 3-Methyl-3-buten-1-yl } \\
\beta \text {-malolactonate }\end{array}$ & 88,89 \\
\hline $\begin{array}{l}\text { (2E)-3,7-Dimethyl-2,6- } \\
\text { octadienol }\end{array}$ & Aspartic acid & 3,7-Dimethyl- $(E)$-2,6-octadien-1-yl & 89 \\
\hline $\begin{array}{c}\text { 2-Tricyclo[3.3.1.1.1,7] } \\
\text { decylethanol }\end{array}$ & Malic acid & $\begin{array}{c}\text { Ethyladamantyl } \beta \text {-malolactonate } \\
\text { MLAEAd }\end{array}$ & 91 \\
\hline $\begin{array}{l}\text { 4-[(Tricyclo[3.3.1.1., }] \text { de- } \\
\text { cylcarbonyl)amino]butanol }\end{array}$ & Malic acid & $\begin{array}{c}\text { Butyladamantanamide } \\
\beta \text {-malolactonate } \\
\text { MLANAd } \\
O_{1}\end{array}$ & 91 \\
\hline$\omega$-Methoxycarbonyloligolactol & $\begin{array}{l}\text { Aspartic acid } \\
\text { (MLAOH } \\
\text { coupled with } \\
\text { ROH by a } \\
\text { Mitsunobu } \\
\text { reaction) }\end{array}$ & $\begin{array}{c}\omega \text {-Methoxycarbonyloligolactyl } \\
\beta \text {-malolactoatne }\end{array}$ & 89 \\
\hline Cholesterol & $\begin{array}{l}\text { Aspartic acid } \\
\text { (MLAOH } \\
\text { coupled with } \\
\text { ROH by a } \\
\end{array}$ & $\begin{array}{c}\text { Cholesteryloxycarbonyl } \\
\beta \text {-malolactonate } \\
\text { MLACho }\end{array}$ & 89 \\
\hline
\end{tabular}




\begin{tabular}{|l|c|c|c|}
\hline Mitsunobu & reaction) & \\
\hline
\end{tabular}




\section{Ring-opening polymerization (ROP) of MLABe}

In contrast to other larger lactones, four-membered ring $\beta$-lactones, substituted or not, such as $\beta$-propiolactone (PL), BL or MLABe, may undergo either an oxygen-acyl or an oxygen-alkyl bond cleavage as a result of their high internal ring-strain and their high polarity (Scheme 8). Depending on the nature of the catalyst/initiator, one opening may be favored over the other. The ROP then proceeds through either a cationic, anionic, coordination-insertion or nucleophilic mechanism, as governed by the class of the catalyst/initiator. ${ }^{58}$

Scheme 8. Ring-opening of a $\beta$-lactone upon either (a) an oxygen-acyl or (b) an oxygen-alkyl bond cleavage

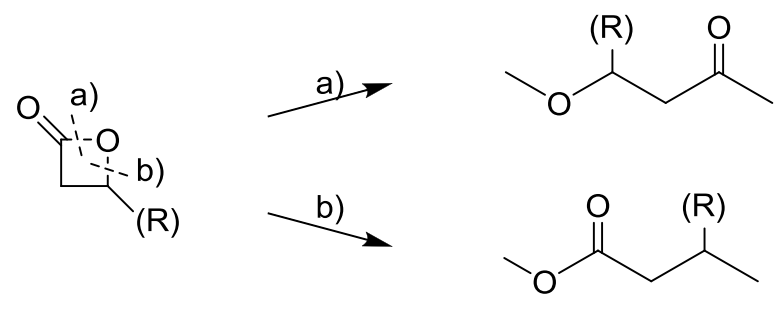

Inspired by the broad variety of catalysts/initiators developed for the ROP of cyclic esters, besides a few enzymes, ${ }^{54-57}$ a wide range of organic, inorganic or metallo-organic species have been reported to successfully ring-open polymerize MLABe. These derivatives can be classified according to the mechanism through which they operate in the ROP of MLABe, i.e. via a cationic, anionic, pseudo-anionic (coordination-insertion), or nucleophilic (activated monomer mechanism) polymerization process (Tables 3,4,5,6).

\subsection{Cationic ROP of MLABe}

Prior to the 1980 s, the ROP of $\beta$-substituted $\beta$-lactones was promoted by acidic compounds through a cationic reaction, then assuming that the steric hindrance of the substituent at the $\beta$-position was prevailing over the role of the initiator. ${ }^{92}$ Lewis acids such as $\mathrm{FeCl}_{3}$ and $\mathrm{AlEt}_{3}$ 
showed, in toluene at $50{ }^{\circ} \mathrm{C}$, similar activities (turn over frequency: TOF $=0.2 \mathrm{~h}^{-1}$ ) for the ROP of rac-MLABe leading to PMLABe (no molar mass values were reported), as described by Vert and Lenz. ${ }^{11,70}$ Noteworthy, AlEt 3 afforded a highly crystalline polymer $\left(T_{\mathrm{m}}=165-185^{\circ} \mathrm{C}\right)$, a stereoselectivity in line with that claimed for the ROP of other alkyl $\beta$-lactones (no further studies have yet confirmed these results). ${ }^{93}$

Table 3. PMLABe synthesized by cationic ROP of MLABe: operating conditions and polymers molecular characteristics

\begin{tabular}{|c|c|c|c|c|c|}
\hline Catalyst/Initiator & $\begin{array}{c}\text { Conditions } \\
\text { (Solvent, reaction } \\
\text { temperature, reaction } \\
\text { time) }\end{array}$ & $\begin{array}{c}M_{\mathrm{w}} \text { or } M_{\mathrm{n}} \\
\left(\mathrm{g} . \mathrm{mol}^{-1}\right) \\
\text { (SEC solvent, } \\
\text { temperature, } \\
\text { standards) }\end{array}$ & $\boldsymbol{D}_{\mathrm{M}}$ & $\begin{array}{l}\text { TOF } \\
\left(h^{-1}\right)\end{array}$ & Ref. \\
\hline $\mathrm{FeCl}_{3}$ & $\begin{array}{c}\text { toluene }(2.5 \mathrm{M}) \text {, bulk, } \\
30-70{ }^{\circ} \mathrm{C}, 7-28 \mathrm{~d}\end{array}$ & $\begin{array}{c}M_{\mathrm{n}} 1800-3200 \\
(-,-, \text { PS })\end{array}$ & $1.9-2.4$ & 0.20 & $11,70,73$ \\
\hline $\mathrm{AlEt}_{3}$ & $\begin{array}{c}\text { toluene }(2.5 \mathrm{M}), \\
50^{\circ} \mathrm{C}, 7 \mathrm{~d} \\
\end{array}$ & 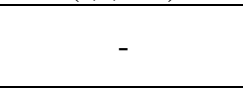 & - & 0.07 & 11,70 \\
\hline $\mathrm{AlCl}_{3}$ & $\begin{array}{c}\text { bulk, } \\
70^{\circ} \mathrm{C}, 20 \mathrm{~d} \\
\end{array}$ & $\begin{array}{c}M_{\mathrm{n}} 1000 \\
(-,-, \mathrm{PS})\end{array}$ & 2.1 & 0.02 & 73 \\
\hline$\left[\left(\mathrm{C}_{6} \mathrm{H}_{5}\right)_{3} \mathrm{C}\right]^{+}\left[\mathrm{SbF}_{6}\right]^{-}$ & $\begin{array}{c}\text { bulk, } \\
30^{\circ} \mathrm{C}, 24 \mathrm{~h}\end{array}$ & $\begin{array}{l}M_{\mathrm{n}} 400 \\
(-,-, \mathrm{PS})\end{array}$ & 2.0 & 0.4 & 73 \\
\hline
\end{tabular}

-: not reported.

Lenz and Guérin have investigated other acidic species, including aluminum chloride $\left(\mathrm{AlCl}_{3}\right)$ or the trityl carbocation $\left(\left[\left(\mathrm{C}_{6} \mathrm{H}_{5}\right)_{3} \mathrm{C}\right]^{+}\left[\mathrm{SbF}_{6}\right]^{-}\right)$, in the cationic bulk ROP of rac-MLABe. ${ }^{72,73}$ However, the former compound was found poorly active at $70{ }^{\circ} \mathrm{C}$ only affording oligomers $\left(M_{\mathrm{n}}=1000 \mathrm{~g} \cdot \mathrm{mol}^{-1}\right)$ after 20 days. Similarly, the latter cationic initiator enabled the same conversion $(10 \%)$ of MLABe within 1 day at $30{ }^{\circ} \mathrm{C}$, giving dimers $\left(M_{\mathrm{n}}=400\right.$ g.mol $\left.{ }^{-1}\right)$.

These same authors also surveyed the performances of $\mathrm{FeCl}_{3}$ in the ROP of the optically active MLABe. ${ }^{73}$ This iron initiator was found more active in bulk rather that in solution leading to the complete conversion of $(S)$-MLABe in 7 days at $70{ }^{\circ} \mathrm{C}$ rather than in 28 days at $30{ }^{\circ} \mathrm{C}$, respectively, giving in both cases oligomers $\left(M \mathrm{n}=1800-3200 \mathrm{~g} \cdot \mathrm{mol}^{-1}, \bigoplus_{\mathrm{M}}=1.9-2.4\right)$. The 
analysis of the optical rotation of the isotactic PMLABe thus formed reflected that the polymerization took place with retention of the initial configuration, thus suggesting that the ROP occurred at the intracyclic ester bond, i.e. with oxygen-alkyl bond rupture.

This bond-rupture hypothesis was later supported by Penczek, ${ }^{94}$ and Kricheldorf, ${ }^{95}$ who showed by NMR and FTIR investigations of the structure of the end-groups, that two different bond scissions, arising from the two nucleophilic positions of the $\beta$-lactone ring (oxygen atoms), could occur in the cationic ROP of the related $\beta$-propiolactone (PL $(\mathrm{R}=\mathrm{H})$, Scheme 9). The attack of the exocyclic oxygen atom in the monomer molecule affords exclusively the oxonium cation active species (Scheme 9b) which undergoes an oxygen-alkyl bond scission. The polymerization propagates via a $\mathrm{S}_{\mathrm{N}} 2$ mechanism with inversion of the configuration at the chiral center and gives polymers with an ester end-group. On the other hand, the attack at the endocyclic oxygen atom in the monomer molecule and the subsequent oxygen-acyl bond scission leads to an acylium cation (Scheme 9a). The polymerization then propagates via a $\mathrm{S}_{\mathrm{N}} 1$ mechanism with retention of the configuration at the chiral center and provides polymers with an ether chain-end. More recently, Albertsson and co-workers also confirmed the predominant endocyclic oxygen attack in the cationic ROP of a lactone, namely 1,5-dioxepan-2-one, mediated by these same Lewis acids. ${ }^{96}$

\section{Scheme 9. General mechanism for the cationic ROP of $\beta$-lactones ${ }^{94,95}$}

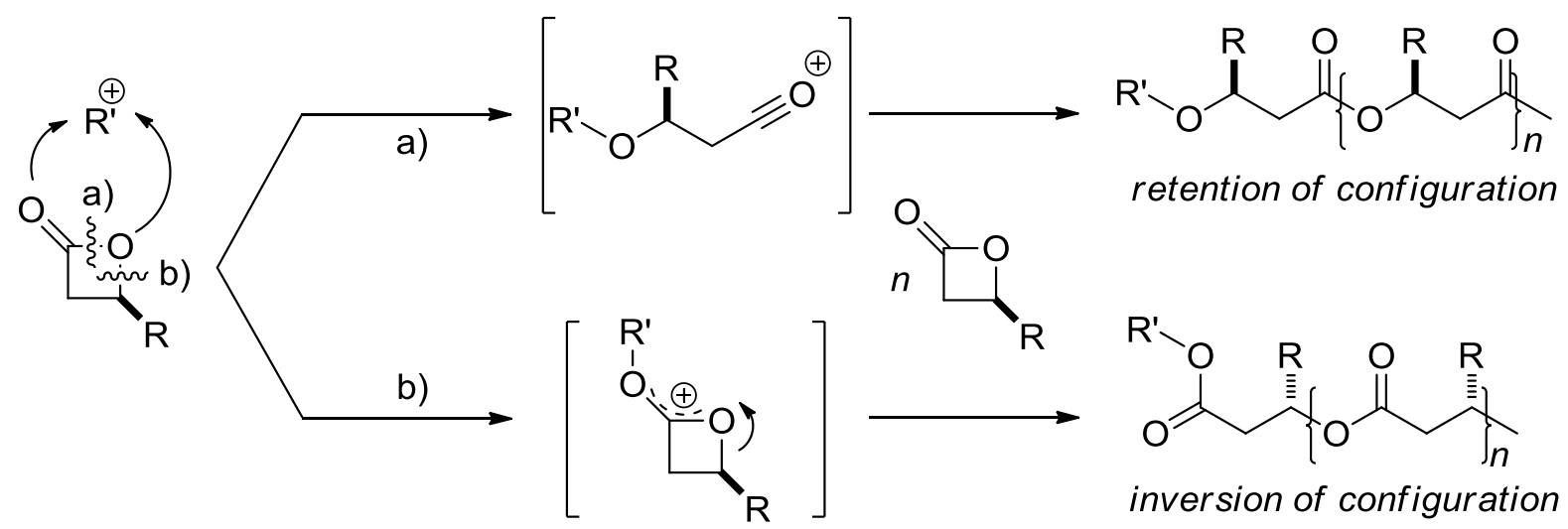


These results illustrate that the ROP of MLABe mediated by cationic species, although better understood than at its initial development, remains less useful than anionic ROP routes (see thereafter) to access high molar mass PMLABe. This trend is reminiscent to the actual knowledge on the cationic ROP of $\beta$-lactones. ${ }^{58}$

\subsection{Anionic ROP of MLABe}

Since the pioneering work of Lenz and Vert evidencing the poor efficiency of the cationic ROP, ${ }^{11,70,73}$ anionic initiators have been favored to promote the ROP of MLABe. Two major classes have been studied, tertiary amines and acetate derivatives as gathered in Table 4 . These different compounds operate through a dissimilar ROP mode.

Table 4. PMLABe synthesized by anionic ROP of MLABe: operating conditions and polymers molecular characteristics

\begin{tabular}{|c|c|c|c|c|c|}
\hline Catalyst/Initiator & $\begin{array}{c}\text { Conditions } \\
\text { (Solvent, reaction } \\
\text { temperature, reaction } \\
\text { time) }\end{array}$ & $\begin{array}{c}M_{\mathrm{w}} \text { or } M_{\mathbf{n}}\left(\mathrm{g} \cdot \mathrm{mol}^{-1}\right) \\
(\mathrm{SEC} \text { solvent, } \\
\text { temperature, } \\
\text { standards) }\end{array}$ & $\boldsymbol{Ð}_{\mathrm{M}}$ & $\begin{array}{l}\text { TOF } \\
\left(h^{-1}\right)\end{array}$ & Ref. \\
\hline $\mathrm{Et}_{3} \mathrm{~N}$ & $\begin{array}{c}\text { Solution, bulk, } \\
25-70{ }^{\circ} \mathrm{C}, 21-40 \mathrm{~d}\end{array}$ & $\begin{array}{c}M_{\mathrm{n}} 7000-19000 \\
\text { (THF/dioxane,-, PS) }\end{array}$ & $1.5-5.0$ & $\begin{array}{c}1.29- \\
41.7 \\
\end{array}$ & $\begin{array}{c}11,70-73, \\
97-99 \\
\end{array}$ \\
\hline Glycine betaine & bulk, RT-60 ${ }^{\circ} \mathrm{C}, 3-29 \mathrm{~d}$ & $\begin{array}{c}M_{\mathrm{n}} 2500-7000 \\
(-,-, \text { PS })\end{array}$ & 1.1 & 13.9 & $\begin{array}{c}11,54,56, \\
57,70\end{array}$ \\
\hline TEABz & $\begin{array}{l}\text { THF }(0.8-2.1 \mathrm{M}), \text { bulk, } \\
37-85^{\circ} \mathrm{C}, 24 \mathrm{~h}-7 \mathrm{~d}\end{array}$ & $\begin{array}{l}M_{\mathrm{n}} 2000-73000 \\
\text { (- or dioxane/ } \mathrm{CHCl}_{3} \text {, } \\
\left.\text { - or } 25{ }^{\circ} \mathrm{C}, \mathrm{PS}\right)\end{array}$ & $1.23-3.3$ & $\begin{array}{l}5.2- \\
25.8\end{array}$ & $\begin{array}{c}11,62,70, \\
72,73,76, \\
88,89,97, \\
100-102\end{array}$ \\
\hline $\mathrm{NaBz}, \mathrm{KBz}$ & Bulk, $60^{\circ} \mathrm{C}, 21-40 \mathrm{~d}$ & $\begin{array}{c}M_{\mathrm{p}} 6200-14000 \\
(\mathrm{THF},-, \mathrm{PS})\end{array}$ & - & - & 72,97 \\
\hline KBz/DB-18-C-6 & $\begin{array}{c}\text { THF, } \mathrm{CH}_{2} \mathrm{Cl}_{2} \text {, benzene } \\
(0.8-2.1 \mathrm{M}), 17-60{ }^{\circ} \mathrm{C}, \\
3-60 \mathrm{~d}\end{array}$ & $\begin{array}{l}M_{\mathrm{n}} 8400-16000 \\
\quad(\mathrm{THF},-, \mathrm{PS})\end{array}$ & $1.3-1.7$ & 10.1 & 72,97 \\
\hline $\begin{array}{c}\text { KAc/DB-18-C-6, } \\
\text { KAc/cryptand [2.2.2] }\end{array}$ & $\begin{array}{c}\mathrm{CH}_{2} \mathrm{Cl}_{2} \text {, bulk, } 20-40{ }^{\circ} \mathrm{C}, \\
20 \mathrm{~h}\end{array}$ & $\begin{array}{c}M_{\mathrm{n}} 56000-130000 \\
\text { (THF,-, universal } \\
\text { calibration) }\end{array}$ & - & - & 61 \\
\hline KPentanoate/18-C-6 & $\mathrm{THF},-{ }^{\circ} \mathrm{C},-$ & $\begin{array}{c}M_{\mathrm{n}} 7200-13650 \\
(\mathrm{THF},-, \text { light } \\
\text { scattering) }\end{array}$ & - & - & 85,103 \\
\hline KHDD/18-C-6 & $\begin{array}{l}\text { THF }(0.2-1.1 \mathrm{M}) \text {, } \\
0-25^{\circ} \mathrm{C}, 120 \mathrm{~min}\end{array}$ & $\begin{array}{c}M_{\mathrm{n}, \mathrm{NMR}} 4800-9300 \\
\left(\mathrm{THF}, 35^{\circ} \mathrm{C}, \mathrm{PS}\right)\end{array}$ & $1.01-1.53$ & 318 & $80,104-107$ \\
\hline $\mathrm{KO}_{2} \mathrm{C}-\mathrm{PEO}-\mathrm{OH} / 18-\mathrm{C}-6$ & $\begin{array}{l}\mathrm{THF}(0.2 \mathrm{M}), \\
0{ }^{\circ} \mathrm{C}, 170 \mathrm{~min}\end{array}$ & $\begin{array}{c}M_{\mathrm{n}, \mathrm{NMR}} 2800-3750 \\
\left(\mathrm{THF}, 45^{\circ} \mathrm{C},\right. \\
\text { PS,PEO) }\end{array}$ & $1.28-1.32$ & - & 108 \\
\hline
\end{tabular}




\begin{tabular}{|c|c|c|c|c|c|}
\hline $\begin{array}{c}\mathrm{KC}_{24} \\
{\left[\mathrm{NMe}_{4}\right]^{+}\left[\mathrm{MeO}-\mathrm{C}_{6} \mathrm{H}_{4}-\right.} \\
\mathrm{CSS}]^{-}\end{array}$ & bulk, $50{ }^{\circ} \mathrm{C}, 120 \mathrm{~h}$ & $\begin{array}{c}M_{\mathrm{w}} 49000,87000 \\
(-,-,-)\end{array}$ & $1.70-1.86$ & - & 109 \\
\hline
\end{tabular}

-: not reported; $M_{\mathrm{p}}$ : molar mass measured at the top of the elution peak

\subsubsection{Anionic ROP of MLABe initiated by tertiary amines}

The use of tertiary amines to mediate the ROP of MLABe, was first reported by Vert and Lenz. ${ }^{11,} 70$ Triethylamine $\left(\mathrm{NEt}_{3}\right)$ promoted the bulk ROP of rac-MLABe $\left([\mathrm{MLABe}]_{0} /\left[\mathrm{NEt}_{3}\right]_{0}=1000\right)$ at $25{ }^{\circ} \mathrm{C}$, leading to the conversion of 650 eq. of monomer after 21 days $\left(\mathrm{TOF}_{25}{ }^{\circ} \mathrm{C}=1.29 \mathrm{~h}^{-1}\right)$ thereby providing PMLABes with $M_{\mathrm{n}}=7000$ g.mol ${ }^{-1} \cdot 11,70$ Complementary studies were performed up to $70^{\circ} \mathrm{C}$ to evaluate the influence of the temperature on the polymerization. ${ }^{71,72,97,98}$ Although the activity of $\mathrm{NEt}_{3}$ increased with the temperature $\left(\mathrm{TOF}_{40}{ }^{\circ} \mathrm{C}=1.38 \mathrm{~h}^{-1} 71,72,97 \mathrm{vs}^{\mathrm{TOF}_{70}{ }^{\circ} \mathrm{C}}=41.7 \mathrm{~h}^{-1}{ }^{98}\right)$, the molar mass values dramatically dropped at $70{ }^{\circ} \mathrm{C}\left(50000\right.$ g.mol ${ }^{-1}$ vs 6000 g. $\mathrm{mol}^{-1}$ at $40{ }^{\circ} \mathrm{C}$ vs $70{ }^{\circ} \mathrm{C}$, respectively). The variation of the dispersity values with temperature $\left(\bigoplus_{\mathrm{M}, 40{ }^{\circ} \mathrm{C}}=1.8\right.$ vs $\left.\bigoplus_{\mathrm{M}, 70{ }^{\circ} \mathrm{C}}=5.0\right)$ underlined the occurrence of side reactions. Indeed, as commonly encountered in the ROP of cyclic esters, undesirable side reactions including intermolecular and intramolecular transesterification reactions as well as chain transfer reactions may occur. ${ }^{110}$ The removal of potentially reactive impuritites (malolactonate carboxylic acid or benzyl alcohol formed upon hydrolysis of the malolactonate benzyl ester during the monomer distillation) from the monomer is essential to access to high molar mass PMLABe from $\mathrm{NEt}_{3}$. Repeated purifications through HPLC and distillations have then enabled to significantly increase the molar mass values. ${ }^{73}$ The PMLABe of highest molar mass $\left(M_{\mathrm{n}}=19000 \mathrm{~g} \cdot \mathrm{mol}^{-1}\right)$ prepared from $\mathrm{NEt}_{3}$ was thus obtained at $60{ }^{\circ} \mathrm{C}$ within 12 days $\left(\mathrm{TOF}=3.3 \mathrm{~h}^{-1}\right) .{ }^{72,99}$ Lenz and co-workers have measured the optical rotation of a PMLABe synthesized from the ROP of enantiopure MLABe $((S)$-MLABe) initiated by $\mathrm{NEt}_{3}{ }^{73,98}$ The authors reported an inversion of the configuration at the chiral center according 
to the general mechanism proposed for the ROP of $\beta$-lactones initiated by a tertiary amine (Scheme 10).

\section{Scheme 10. Proposed mechanism for the ROP of $\beta$-lactones initiated by NEt $_{3}{ }^{111}$}

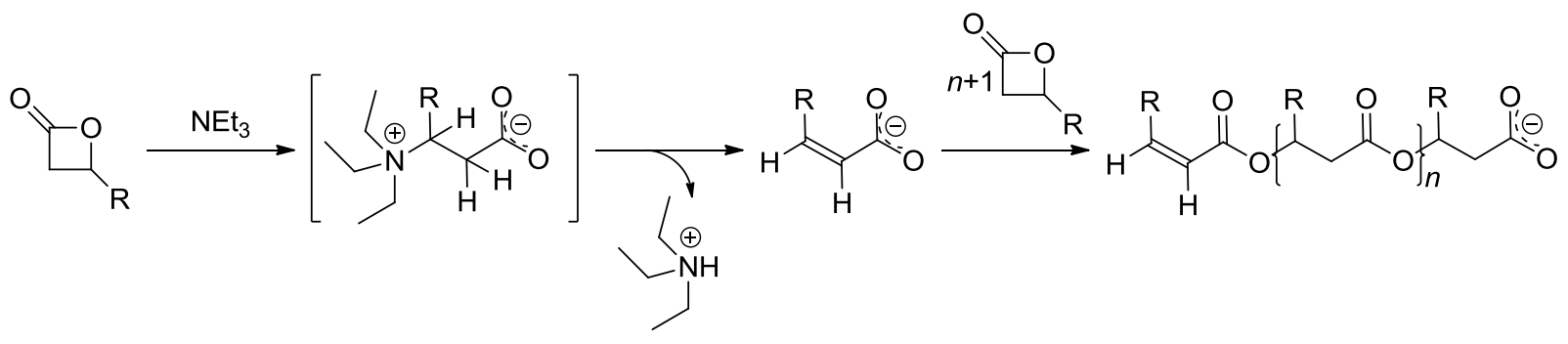

As evidenced from the studies reported by Kricheldorf and co-workers on the ROP of PL initiated by tertiary amines, the ROP of $\beta$-lactones is proposed to proceed via an additionelimination step as illustrated in Scheme 10 with $\mathrm{NEt}_{3}{ }^{111}$ This particular mechanism, supported by spectroscopic evidences on the nature of end-chain groups, ${ }^{111}$ leads to the formation of an unsaturated propagating moiety obtained from a betaine intermediate, affording, with inversion of the configuration, functional polymers with unsaturated end-groups. Trimethylglycine (glycine betaine), a zwiterionic species similar to this key intermediate, was found to enable the ROP of $r a c-M L A B e .{ }^{11,56,57,70}$ In bulk and at RT, this initiator showed similar activities to $\mathrm{NEt}_{3}$ (800 equiv converted in 21 days) affording PMLABes with a molar mass up to $M_{\mathrm{n}}=7000$ g.mol ${ }^{-1}$. However, when the polymerization was conducted at $60{ }^{\circ} \mathrm{C}$, full conversion of racMLABe $\left([\mathrm{rac}-\mathrm{MLABe}]_{0} /[\mathrm{glycine} \text { betaine }]_{0}=1\right.$ 000) was reached within 3 days, leading to PMLABe oligomers $\left(M_{\mathrm{n}}=2500 \mathrm{~g} \cdot \mathrm{mol}^{-1}\right)$.

In a particular study, Guérin and co-workers ${ }^{99}$ used ${ }^{14} \mathrm{C}$-radiolabelled $\mathrm{NEt}_{3}$ to promote the ROP of rac-MLABe so as to follow the in vivo fate of the PMLABe after intravenous injection in mice. The approach followed was to end-cap the PMLABe chain with ${ }^{14} \mathrm{C}-\mathrm{Et}_{3} \mathrm{~N}$, based on the general observation that the anionic ROP of $\beta$-lactones leads to polyesters end- 
capped with the initiator at one terminus. ${ }^{58,112}$ The radioactivity of the PMLABe then recovered after successive purifications, although much lower than expected, was sufficient enough to monitor the fate of the polymer. Based on the observed radioactivity of the PMLABe (no other evidence was reported), formation of $\alpha$-triethyl ammonium, $\omega$-carboxylic acid functionalized PMLABe was thus suggested (Scheme 11). ${ }^{99}$ The hinted zwitterionic propagating species suggested that the amine initiator was not eliminated from the (growing) polymer chains. This behavior was in contrast with the one reported by Kricheldorf and co-workers for the similarly $\mathrm{NEt}_{3}$ promoted ROP of rac-MLABe, as just mentioned above (Scheme 9). ${ }^{111,113}$ However, it is reminiscent to the mechanism proposed by Guillaume and co-workers on the organocatalyzed ROP of $\beta$-lactones (BL and MLABe) in which the final polyester is covalently bounded to the organic base (vide infra). ${ }^{83,114}$

\section{Scheme 11. The zwiterionic ROP of rac-MLABe initiated by ${ }^{14} \mathrm{C}$-radiolabelled $\mathrm{Et}_{3} \mathrm{~N}^{99}$}

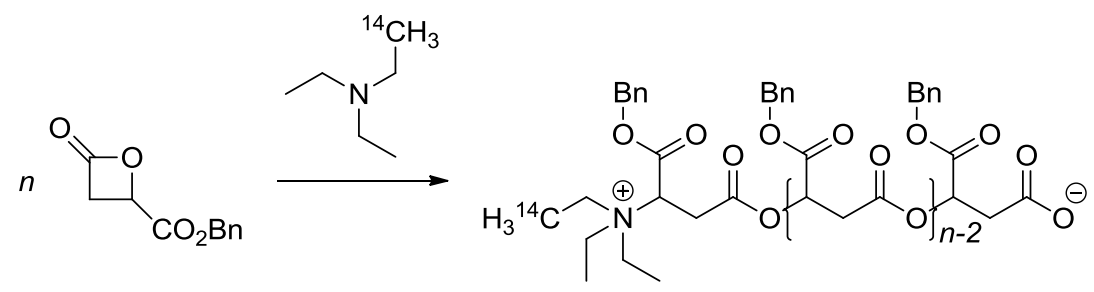

\subsubsection{Anionic ROP of MLABe initiated by acetate derivatives}

Anionic polymerization of MLABe initiated by acetate derivatives has been widely studied. Various parameters have been evaluated such as the nature of the substituent on the carboxylate moiety, the nature and the size of the counterion, the presence or the absence of a chelating cationic agent.

The benzoate moiety is the acetate derivative which has been most widely investigated. Vert and Lenz have shown that tetraethyl ammonium benzoate (TEABz) was able to convert 400 equiv of rac-MLABe (conv. $40 \%$ ) at $50{ }^{\circ} \mathrm{C}$ in bulk within 7 days yet, only providing 
oligomers $\left(M_{\mathrm{n}}=2000\right.$ g.mol $\left.{ }^{-1}\right) .{ }^{11,70}$ Cammas and co-workers and Guérin and co-workers have shown that the synthesis of high molar mass PMLABes from TEABz was highly dependent on the purity of the monomer used. ${ }^{62,88}$ After drastic purifications of the intermediate products and of the ultimate MLABe, PMLABes with molar masses up to $M_{\mathrm{n}}=73000 \mathrm{~g} \cdot \mathrm{mol}^{-1}\left(\bigoplus_{\mathrm{M}}=\right.$ 1.7-3.3) were obtained after 3 days in bulk at $37{ }^{\circ} \mathrm{C}\left(\mathrm{TOF}=2.8 \mathrm{~h}^{-1}\right)$. TEABz was found more active at higher temperatures in the range $50-85^{\circ} \mathrm{C}\left(\mathrm{TOF}\right.$ up to $\left.26 \mathrm{~h}^{-1}\right) .{ }^{62,72,76,97}$ Nevertheless, unlike with $\mathrm{NEt}_{3}$, the increase of the temperature did not alter the control of the reaction, affording PMLABes with $13000<M_{\mathrm{n}}<55000$ g.mol ${ }^{-1}$ with similar dispersity values as those obtained from lower reaction temperatures $\left(\bigoplus_{M}=1.3-2.9\right)$. More recently, Chiellini and coworkers and Solaro and co-workers have used TEABz to evaluate the effect of the bulkiness of the $\beta$-lactone substituent on the polymerization of MLARs, which showed the dependence of the rate of polymerization on the steric interactions between the lateral group of the monomer and the growing polymer active end-group. ${ }^{89,100}$ The effect of the benzoate counterion on the ROP of MLABe has been investigated by Lenz and Vert upon comparing sodium and potassium cations to tetraethyl ammonium salt. ${ }^{72,97}$ Optimized conditions were obtained with TEABz rather than with sodium or potassium derivatives. In bulk at $60{ }^{\circ} \mathrm{C}$, systems derived from these latter two cations afforded PMLABes with molar mass values $\left(M_{\mathrm{n}}\right)$ as high as $14000 \mathrm{~g} . \mathrm{mol}^{-1}$ vs 27000 g.mol ${ }^{-1}$ measured for PMLABes prepared from TEABz. Also, under these conditions, the polymerization rate was much slower for sodium and potassium counter ions, similarly following the variations of the size of the ion $\left(\mathrm{Et}_{4} \mathrm{~N}^{+}>\mathrm{K}^{+}>\mathrm{Na}^{+}\right)$.

The polymerization of MLABe in solution was instigated in tetrahydrofuran using either potassium benzoate combined to a chelating agent (dibenzo-18-C-6) (DB18-C-6), or TEABz. While the polymerization rates were improved through bulk procedures, lower molar mass values and lower polymerization rates were generally obtained in solution as compared to bulk 
reaction media, for comparable reaction times and temperature. ${ }^{72,97}$ The use of a chelating cationic agent with potassium acetate derivatives was mentioned in the literature as an efficient strategy to access to PMLABe in a controlled approach. Guérin reported the use of the simple potassium acetate with dibenzo-18-C-6 (DB-18-C-6), affording PMLABes with high molar mass values $\left(M_{\mathrm{n}}=56000-130000 \mathrm{~g} \cdot \mathrm{mol}^{-1}\right) \cdot{ }^{61}$ Cammas and co-workers have similarly reported the synthesis in THF of PMLABe $\left(M_{\mathrm{n}, \mathrm{NMR}}=9000-17000 \mathrm{~g} \cdot \mathrm{mol}^{-1}\right)$ with an unsaturated chainend from potassium pentanoate/18-C-6. ${ }^{85,103}$ Dubois and co-workers have explored the possibility to initiate the anionic polymerization of rac-MLABe with potassium 11hydroxydodecanoate $\left.\left(\mathrm{KCO}_{2}\left(\mathrm{CH}_{2}\right)_{11} \mathrm{OH}\right), \mathrm{KHDD}\right)$ in presence of $18-\mathrm{C}-6 .{ }^{80,104-107}$ At $25^{\circ} \mathrm{C}$ in solution in THF, this system was very active $\left(\mathrm{TOF}=318 \mathrm{~h}^{-1}\right)$ at low monomer loading $([\mathrm{rac}$ $\left.\mathrm{MLABe}]_{0} /[\mathrm{KHDD} / 18-\mathrm{C}-6]_{0}=50 ;[\mathrm{rac}-\mathrm{MLABe}]_{0}=1.1 \mathrm{~mol} . \mathrm{L}^{-1}\right)$. This strategy afforded $\alpha-$ hydroxy, $\omega$-carboxylic acid PMLABes $\left(M_{\mathrm{n}, \mathrm{NMR}}=4\right.$ 800-9 200 g.mol $\left.{ }^{-1}\right)$ with fairly narrow dispersities $\left(\bigoplus_{\mathrm{M}}=1.01-1.3\right)$. These polymers could be further functionalized by esterification, reduction or copolymerization. Finally, carboxylate end-capped poly(ethylene oxide) (PEO) was also used as a macroinitiator in the presence of $18-\mathrm{C}-6$ for the ROP of the rac-MLABe, ultimately affording star-shaped PMLABe- $b$-PEO copolymers. ${ }^{108}$

Investigations on the mechanism of the ROP of MLAR bearing an hydrogen atom in $\alpha$-position of the carbonyl and initiated by acetate derivatives (Table 4), showed that the initiation proceeds according to two different pathways (Scheme 12), as reported by Masure and co-workers and Dubois and co-workers. ${ }^{61,80}$ The carboxylate anion $\left(\mathrm{R}^{\prime} \mathrm{COO}^{-}\right)$attacks the carbon atom in $\beta$-position of the carbonyl group of the $\beta$-lactone (Scheme 12a), affording a propagating carboxylate species. Alternatively, the carboxylate anion can act as a base and directly attacks the proton in $\alpha$-position of the carbonyl group of the $\beta$-lactone (Scheme $12 b$ ). This proton abstraction which can be mediated by the initiator or the active chain-end, then 
leads to an unsaturated carboxylate propagating moiety. From both these carboxylate species, the propagation proceeds through a $\mathrm{S}_{\mathrm{N}} 2$ mechanism with inversion of the configuration at the chiral center (refer to Scheme 8). The authors also reported that intramolecular proton abstraction reactions can occur on the polymer backbone (Scheme 12b'), thereby limiting the control of the molar mass and of the nature of the chain end-group of the PMLAR formed.

Scheme 12. Proposed mechanism for the ROP of MLABe initiated by an acetate derivative $\mathrm{R}^{\prime} \mathrm{COO}^{-61,80}$

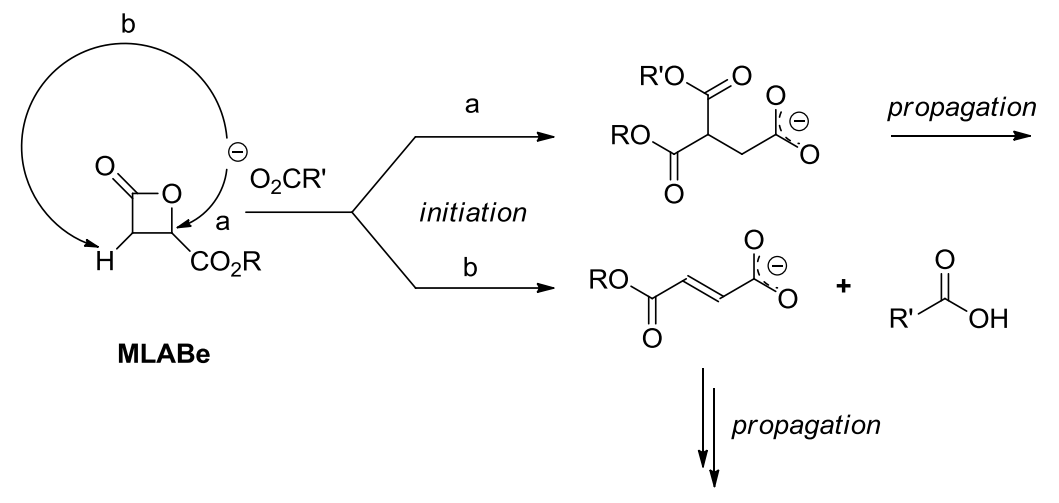<smiles>[R6]C(=O)C(CC(=O)OC(CC(=O)O)C(=O)O)C(=O)OCC(=O)O</smiles>

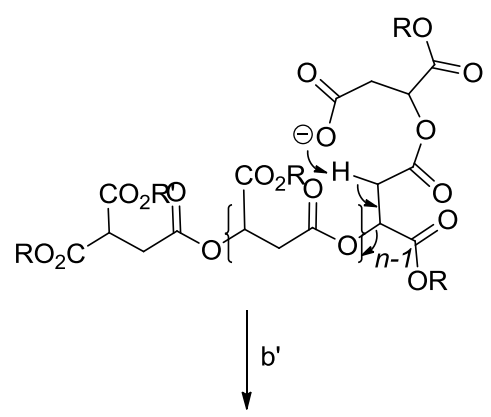

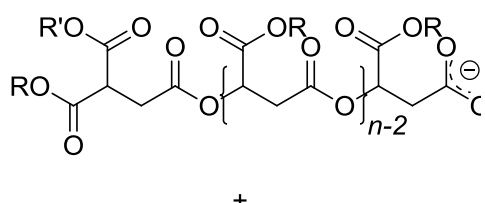

More exotic initiating systems were also reported for the anionic ROP of MLABe. Vert and co-workers prepared high molar mass PMLABes from a dithioate (tetramethyl ammonium 4-methoxybenzodithioate, $\left[\mathrm{NMe}_{4}\right]^{+}\left[\mathrm{MeO}-\mathrm{C}_{6} \mathrm{H}_{4}-\mathrm{CSS}\right]^{-}$) and more interestingly by $\mathrm{KC}_{24}$ graphite intercalation compound. ${ }^{109}$ These two species, in bulk monomer at $50{ }^{\circ} \mathrm{C}$, afforded 
PMLABe with $M_{\mathrm{w}}=49000$ and 87000 g.mol ${ }^{-1}$, respectively. The $\mathrm{KC}_{24}$ system can be related to the potassium naphtalate used by Cammas and co-workers ${ }^{103}$ for the copolymerization of $\beta$ malolactonates.

\subsection{Pseudo-anionic ROP of MLABe}

In order to improve the control of the polymerization, more selective catalysts/initiators were investigated. Metallo-organic species, working through a coordination-insertion process, have been found as good catalysts for the ROP of MLABe. Although the mechanism proposed to take place has not always been clearly established, the different catalysts/initiators which have been reported in the pseudo-anionic ROP of MLABe, as gathered in Table 5, most often operate through a coordination-insertion process.

Table 5. PMLABe synthesized by pseudo-anionic ROP of MLABe: operating conditions and polymers molecular characteristics

\begin{tabular}{|c|c|c|c|c|c|}
\hline Catalyst/Initiator & $\begin{array}{c}\text { Conditions } \\
\text { (Solvent, reaction } \\
\text { temperature, reaction } \\
\text { time) }\end{array}$ & $\begin{array}{c}M_{\mathrm{w}} \text { or } M_{\mathrm{n}} \text { range } \\
\left({\left.\mathrm{g} . \mathrm{mol}^{-1}\right)}\right. \\
(\mathrm{SEC} \text { solvent, } \\
\text { temperature, } \\
\text { standards) } \\
\end{array}$ & $\boldsymbol{D}_{M}$ & $\begin{array}{l}\text { TOF } \\
\left(h^{-1}\right)\end{array}$ & Ref. \\
\hline (TPP)Al(OMe) & bulk, $50{ }^{\circ} \mathrm{C}, 30 \mathrm{~d}$ & $\begin{array}{c}M_{\mathrm{p}} 30000-35000 \\
\text { (THF,dioxane,-, } \\
\text { PS) } \\
\end{array}$ & $1.5-2.0$ & 1.11 & 71 \\
\hline MAO, EAO & toluene, $60^{\circ} \mathrm{C}, 7-14 \mathrm{~d}$ & $\begin{array}{l}M_{\mathrm{n}} 15000-41000 \\
\quad\left(\mathrm{CHCl}_{3},-, \mathrm{PS}\right)\end{array}$ & $5.6-24$ & - & 115,116 \\
\hline $\begin{array}{c}\mathrm{Sn}(\mathrm{Oct})_{2} / \\
\mathrm{P}(\mathrm{MLAHe}-\mathrm{co}-\mathrm{MLAHP})\end{array}$ & $\begin{array}{c}\text { THF }(1.27 \mathrm{M}), 80^{\circ} \mathrm{C}, \\
90 \mathrm{~h}\end{array}$ & $\begin{array}{c}M_{\mathrm{n}} 5300 \\
\left(\mathrm{THF}, 35^{\circ} \mathrm{C}, \mathrm{PS}\right)\end{array}$ & 1.44 & - & 117 \\
\hline $\begin{array}{c}{\left[(\mathrm{BDI}) \mathrm{Zn}\left\{\mathrm{N}\left(\mathrm{SiMe}_{3}\right)_{2}\right\}\right] /} \\
\mathrm{BnOH}, \mathrm{iPrOH}\end{array}$ & bulk, $40-60{ }^{\circ} \mathrm{C}, 3-6 \mathrm{~h}$ & $\begin{array}{c}M_{\mathrm{n}, \mathrm{NMR}} \\
2000-17100\end{array}$ & $1.12-1.42$ & 32 & 82,118 \\
\hline
\end{tabular}

-: not reported; $M_{\mathrm{p}}$ : molar mass measured at the top of the elution peak

As briefly reported by Guérin and co-workers, $(O$-methoxy tetraphenylporphyrin aluminium) (TPP)Al( $\left.\mathrm{OCH}_{3}\right)$ successfully ring-open polymerized $\mathrm{rac}-\mathrm{MLABe}$ in bulk at $50{ }^{\circ} \mathrm{C}$, affording the polyester with a molar mass of $M_{\mathrm{p}}$ up to $35000 \mathrm{~g} \cdot \mathrm{mol}^{-1}$, yet with a poor efficiency ( $80 \%$ in 30 days vs only 7 days for the $\mathrm{NEt}_{3}$-mediated ROP, under the same operating conditions 
(Table 4)). ${ }^{71}$ A more effective method to polymerize rac-MLABe was developed by Gross and co-workers using aluminoxane species such as methylaluminoxane (MAO) and ethylaluminoxane (EAO), prepared in situ by reaction of the corresponding trialkyl aluminum with water. ${ }^{115,} 116$ Within 1 or 2 weeks, high molar mass PMLABes were obtained $\left(M_{\mathrm{n}}=\right.$ $15000-41000$ g.mol $\left.^{-1}\right)$; yet the polymers exhibited very high dispersity values $\left(\bigoplus_{\mathrm{M}}=8-24\right)$ indicating a poor control of the polymerization. PMLABes thus formed were fractionated into an acetone-soluble and an acetone-insoluble portions. Interestingly, while the acetone-soluble fraction gave PMLABes with low molar mass $\left(M_{\mathrm{n}}<16000 \mathrm{~g} \cdot \mathrm{mol}^{-1}, \bigoplus_{\mathrm{M}}=4.0\right)$ and low stereoregularity, the acetone-insoluble fraction provided higher molar mass $\left(M_{\mathrm{n}}\right.$ up to 69000 g.mol ${ }^{-1}, \bigoplus_{\mathrm{M}}=9.9$ ) and highly crystalline (up to $88 \%$ isotactic; $T_{\mathrm{m}}=176-190{ }^{\circ} \mathrm{C}$ ) PMLABes. Along with ${ }^{13} \mathrm{C}$ NMR studies, in particular of the methine region, this thermal behavior evidenced the stereocontrol imparted by the aluminum-based initiator.

More recently, Dubois and co-workers reported the activity of tin(II) bis(2ethylhexanoate) (tin octoate, $\mathrm{Sn}(\mathrm{Oct})_{2}$ ) in the ROP of $r a c$-MLABe using a copolymer of hexyl $\beta$-malolactonate (MLAHe) and propanol $\beta$-malolactonate, P(MLAHe-co-MLAHP) bearing pendant hydroxyl groups, as a macroinitiator. ${ }^{117}$ This copolymer was first obtained upon deprotection of the corresponding MLAHe/benzyloxypropyl $\beta$-malolactonate (MLABP) copolymer (P(MLAHe-co-MLABP)). This approach allowed the preparation of graft copolymers $\mathrm{P}(\mathrm{P}(\mathrm{MLAHe}-c o-\mathrm{MLAHP})-g-\mathrm{MLABe})$ in $90 \mathrm{~h}$ at $80{ }^{\circ} \mathrm{C}$ in $\mathrm{THF}$.

Finally, the in situ initiator preparation route has also been developed by Guillaume and co-workers with the controlled ROP of rac-MLABe initiated by the zinc $\beta$-diketiminate $\left[(\mathrm{BDI}) \mathrm{Zn}\left\{\mathrm{N}\left(\mathrm{SiMe}_{3}\right)_{2}\right\}\right]\left(\mathrm{BDI}=\mathrm{CH}\left(\mathrm{CMeNC}_{6} \mathrm{H}_{3}-2,6-{ }^{i} \mathrm{Pr}_{2}\right)_{2}\right)$ combined to an alcohol $(\mathrm{ROH}$, with $\left.\mathrm{R}=\mathrm{BnOH},{ }^{i} \mathrm{PrOH}\right)$ acting as a co-initiator and as a chain transfer agent. ${ }^{82,118}$ The catalytic systems were shown to be active under mild conditions at $40-60{ }^{\circ} \mathrm{C}$ in bulk, and under immortal ROP conditions ${ }^{119,120}$ (up to 5 equiv of ROH), thereby enabling to lower the initial loading of 
the zinc species $(0.2 \%)$. At $60{ }^{\circ} \mathrm{C}$ in presence of ${ }^{i} \mathrm{PrOH}$, this system showed a good activity, converting 95 equiv of MLABe in $3 \mathrm{~h}$ (TOF $\left.=32 \mathrm{~h}^{-1}\right)$. Well-defined $\alpha$-hydroxy, $\omega$-alkoxy telechelic PMLABes were thus prepared with controlled molar mass values $\left(M_{\mathrm{n}, \mathrm{NMR}}=2000-17100 \mathrm{~g} \cdot \mathrm{mol}^{-1}\right)$, and fairly narrow dispersity values $\left(\bigoplus_{\mathrm{M}}=1.12-1.40\right)$. The living feature of the ROP process next allowed the synthesis of block and random copolymers. ${ }^{118}$

The proposed mechanism for the ROP of MLABe mediated by this zinc system is similar to the one initially established with $\beta$-butyrolactone, the related commercially available $\beta$-lactone (Scheme 13). ${ }^{121-123}$ Initially, the in situ reaction of the amido precursor with alcohol $\left(\mathrm{R}^{\prime} \mathrm{OH}\right)$ results in the formation of the alkoxide complex "[(BDI)Zn(OR')]", which is the real initiating species. Incoming $\beta$-lactone then undergoes coordination-insertion into the resulting zinc-oxygen bond with oxygen-acyl bond cleavage of the monomer. Propagation proceeds with the growth of the polymer chain from the zinc center. Concomitant chain transfer from growing polymer chains with (macro)molecules of alcohol ultimately gives the HO-PHAs-OR' polymers.

Scheme 13. Proposed mechanism for the coordination-insertion ROP of a $\beta$-lactone mediated by the $\left[(\mathrm{BDI}) \mathrm{Zn}\left\{\mathrm{N}\left(\mathrm{SiMe}_{3}\right)_{2}\right\}\right] \mathrm{R}^{\prime} \mathrm{OH}$ system $^{121-123}$ 


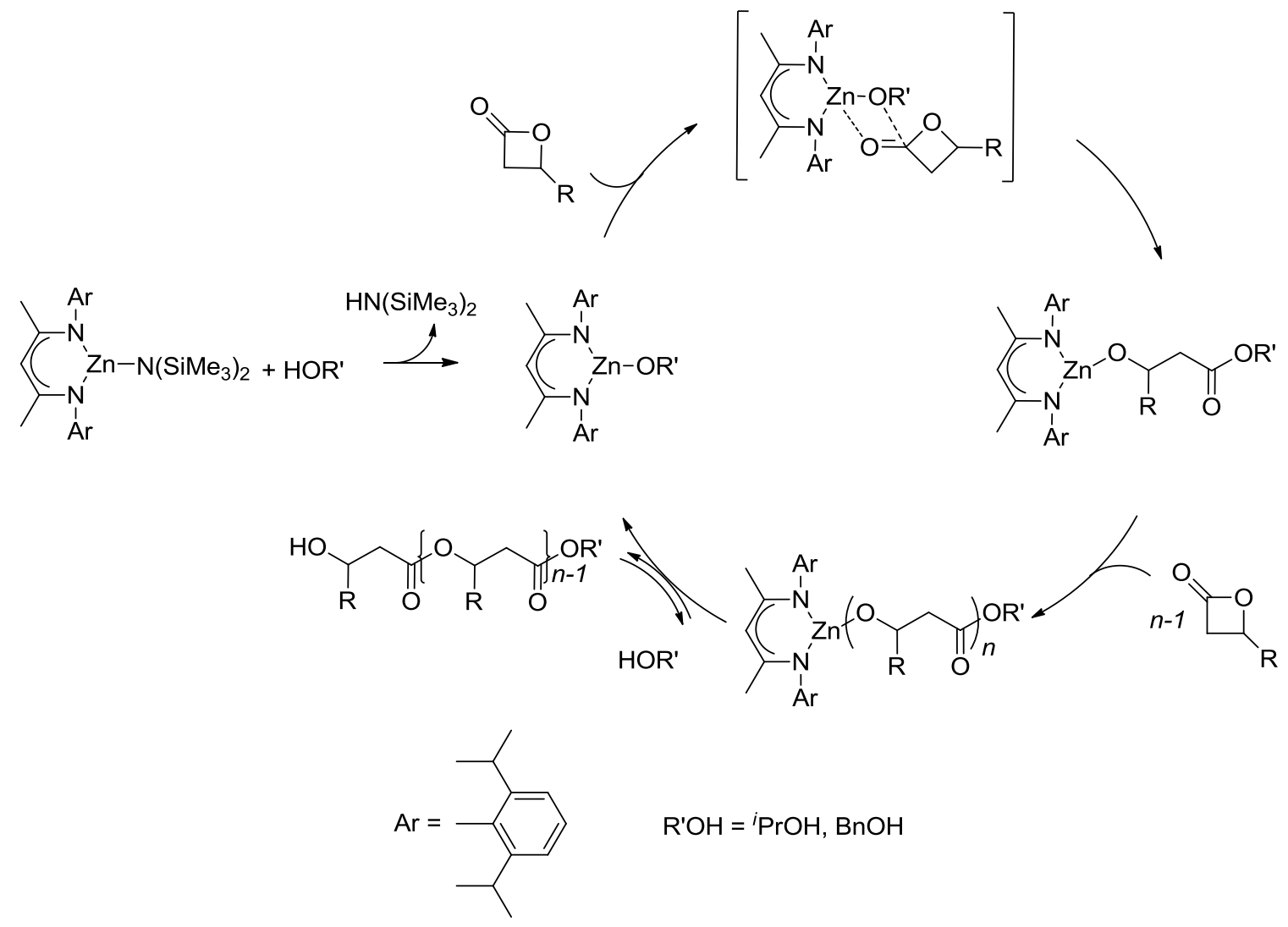

\subsection{Nucleophilic ROP of MLABe}

The ROP of MLABe was recently improved using nucleophilic species. The different catalysts/initiators which have been reported in the nucleophilic ROP of MLABe, as gathered in Table 6, most often operate through a coordination-insertion process.

Table 6. PMLABe synthesized by nucleophilic ROP of MLABe: operating conditions and polymers molecular characteristics

\begin{tabular}{|c|c|c|c|c|c|}
\hline Catalyst/Initiator & $\begin{array}{c}\text { Conditions } \\
\text { (Solvent, reaction } \\
\text { temperature, reaction } \\
\text { time) }\end{array}$ & $\begin{array}{c}\boldsymbol{M}_{\mathbf{w}} \text { or } \boldsymbol{M}_{\mathbf{n}} \\
\left(\mathbf{g . m o l} \mathbf{l}^{-\mathbf{1}}\right) \\
(\mathbf{S E C} \text { solvent, } \\
\text { temperature, } \\
\text { standards) }\end{array}$ & $\boldsymbol{D}_{\mathbf{M}}$ & $\begin{array}{c}\text { TOF } \\
\left(\mathbf{h}^{-1}\right)\end{array}$ & Ref. \\
\hline $\begin{array}{c}\mathrm{M}(\mathrm{OTf})_{3} / \mathrm{BnOH} \\
\mathrm{M}=\mathrm{Al}, \mathrm{Nd}, \mathrm{Bi}\end{array}$ & bulk, $40-60^{\circ} \mathrm{C}, 2-18 \mathrm{~h}$ & $\begin{array}{c}M_{\mathrm{n}} 1200-3100 \\
\left(\mathrm{THF}, 30^{\circ} \mathrm{C}, \mathrm{PS}\right)\end{array}$ & $1.20-1.53$ & 16.7 & 82,118 \\
\hline $\mathrm{TBD}$ & bulk, $60^{\circ} \mathrm{C}, 1-10 \mathrm{~h}$ & $\begin{array}{c}M_{\mathrm{n}, \mathrm{NMR}} * \\
8100-80400\end{array}$ & $1.15-1.35$ & 46.0 & 83 \\
\hline $\mathrm{DBU}$ & bulk, $60^{\circ} \mathrm{C}, 30-150 \mathrm{~min}$ & $\begin{array}{c}M_{\mathrm{n}, \mathrm{NMR}} * \\
9500-39500\end{array}$ & $1.25-1.31$ & 100 & 83 \\
\hline $\mathrm{BEMP}$ & bulk, $60^{\circ} \mathrm{C}, 20-100 \mathrm{~min}$ & $\begin{array}{c}M_{\mathrm{n}, \mathrm{NMR}} * \\
10300-44200\end{array}$ & $1.12-1.39$ & 141 & 83 \\
\hline
\end{tabular}


-: not reported; $M_{\mathrm{p}}$ : molar mass measured at the top of the elution peak; ${ }^{*}$ The signals corresponding to the organobase hydrogens correspond to a significant number of hydrogens in the initiator and emerge well from the spectrum baseline, thus allowing the reliable determination of the molar mass by NMR analysis.

Triflate metallic salts $\left(\mathrm{M}(\mathrm{OTf})_{3} ; \mathrm{M}=\mathrm{Al}, \mathrm{Nd}, \mathrm{Bi}\right)$ associated to an alcohol $(\mathrm{BnOH}$, $\left.{ }^{i} \mathrm{PrOH}\right)$ as a co-initiator and as a chain transfer agent, also promoted the controlled immortal ROP of rac-MLABe. ${ }^{82,118}$ The bulk ROP carried out at $40-60{ }^{\circ} \mathrm{C}$ gave PMLABes with molar mass ranging from $M_{\mathrm{n}, \mathrm{NMR}}=1200$ to $3100 \mathrm{~g} \cdot \mathrm{mol}^{-1}$. The bismuth triflate showed the highest activity $\left(\mathrm{TOF}=46 \mathrm{~h}^{-1}\right)$ and also the lowest control as hinted by the largest dispersity value obtained from this metallic salt $\left(\bigoplus_{\mathrm{M}}=1.53\right)$. Among these triflate salts, $\mathrm{AlOTf}_{3}$ afforded the best compromise for the ROP of rac-MLABe, affording the lowest dispersity value $\left(\bigoplus_{\mathrm{M}}=\right.$ 1.20-1.24) and a fairly good activity $\left(\mathrm{TOF}=17 \mathrm{~h}^{-1}\right)$. NMR characterization demonstrated the $\alpha$-hydroxy, $\omega$-alkoxy end-capping of the PMLABes. The living characteristic of the ROP further enabled the synthesis of copolymers from the neodymium-based catalytic system. The metallic triflates most likely operate through an activated monomer mechanism as previously established for the ROP of $\beta$-butyrolactone and other related cyclic esters such as carbonates. ${ }^{119}$, 120,124

Following the general interest in the organocatalyzed ROP of cyclic esters as recently reviewed. ${ }^{125-130}$ Guillaume and co-workers investigated the ROP of $\beta$-lactones and in particular of $r a c-B L$ and $r a c-M L A B e$, mediated by organocatalysts of the guanidine $(1,5,7-$ triazabicyclo[4.4.0]dec-5-ene, TBD ), amidine (1,8-diazabicyclo[5.4.0]-undec-7-ene, DBU) and phosphazene (2-tert-butylimino-2-diethylamino-1,3-dimethylperhydro1,3,2diazaphosphorine, BEMP) types. ${ }^{83,114}$ Note that prior to this work, TBD and DBU were reported as inactive towards the ROP of $\beta$-butyrolactone at $50{ }^{\circ} \mathrm{C} .{ }^{131-133}$ The authors thus showed that, under specific conditions (bulk, $60^{\circ} \mathrm{C}$ ), these tertiary amines were rather fairly active towards the ROP of rac MLABe (TOF = $50(\mathrm{TBD}), 100(\mathrm{DBU})$ and $150 \mathrm{~h}^{-1}(\mathrm{BEMP})$ ), 
affording $\alpha$-guanidine/amidine/phosphazene, $\omega$-benzyloxycarbonyl crotonate PMLABes with controlled molecular features, i.e. controlled molar mass values $\left(M_{\mathrm{n}, \mathrm{NMR}}=8000-80000\right.$ g.mol $\left.{ }^{-1}\right)$, narrow dispersity values $\left(\bigoplus_{M}=1.1-1.4\right)$ and well-defined end-groups. ${ }^{83,114}$ Evidences of the covalent end-capping of the polyesters by the organic base at one chain end and by a crotonate at the other terminus, relied on detailed ${ }^{1} \mathrm{H}$ and ${ }^{13} \mathrm{C}$ NMR spectroscopic and MALDIToF mass spectrometry analyses. These latter initiators have shown high activities for the ROP of MLABe (TON = 50 (TBD), $100(\mathrm{DBU})$ and $150 \mathrm{~h}^{-1}$ (BEMP)). A mechanism was proposed, different from the pseudo-anionic ROP mechanism, to explain the formation of $\alpha$-base, $\omega$ crotonate PMLABes (Scheme 13). The $\beta$-lactone is ring-opened by the base affording a 1:1 base-malate adduct, as already shown by Hedrick. ${ }^{133}$ Following the dehydration of this adduct - herein made possible at $60{ }^{\circ} \mathrm{C}$-, subsequent propagation would occur via insertion of the monomer between the base and the crotonate end-group, ultimately leading to the recovered PMLABe end-capped by the base and a crotonate group. The proposed mechanism from DBU and BEMP, although not fully established, is believed to similarly involve the formation of an organobase- $N$-acyl-crotonate active species, upon hydroxide abstraction (Scheme 14). Finally, given the demonstrated controlled and living features of the ROP of rac-MLABe, these metalfree initiators were subsequently used for the copolymerization of MLABe with BL (vide infra). ${ }^{118}$

\section{Scheme 14. Proposed nucleophilic mechanism for the ROP of a $\beta$-lactone mediated by}

\section{TBD $^{83}$}




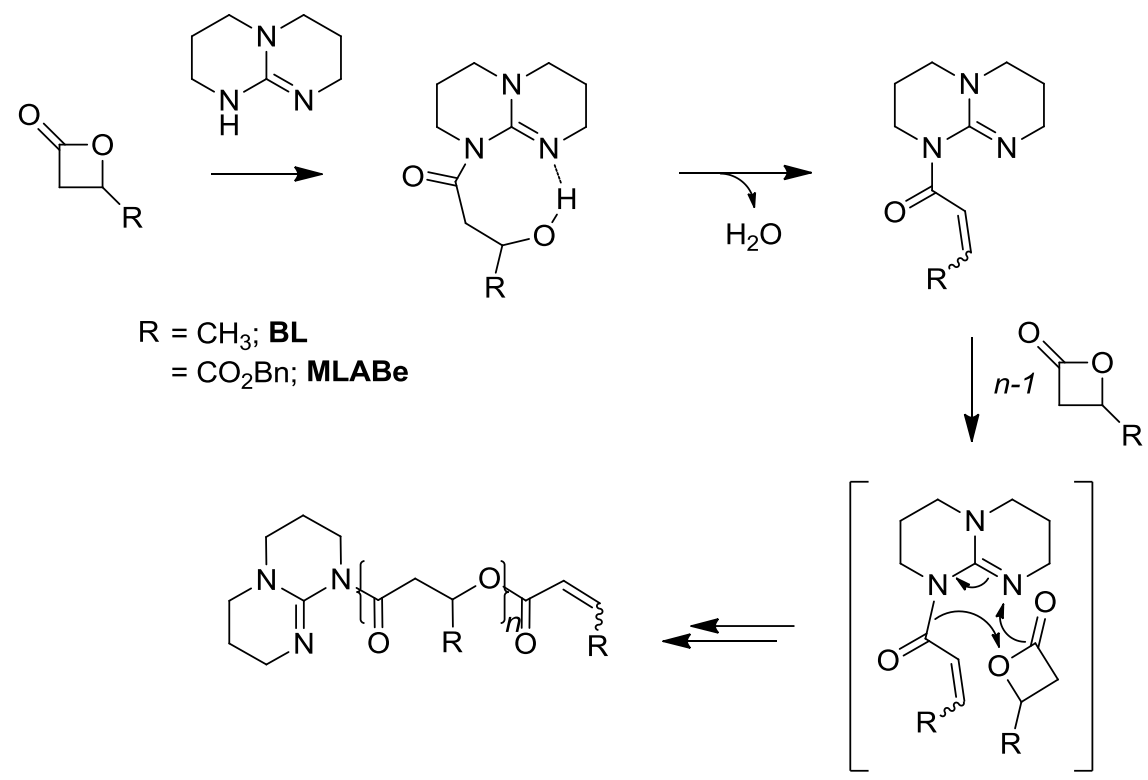

$N$-Heterocyclic carbenes (NHCs)-based polymerization of $\beta$-lactones has been well studied $^{125}$ including the ROP of $\beta$-butyrolactone ${ }^{134-137}$ and of dimethyl benzyl $\beta$-malolactonate $\left(\mathrm{Me}_{2} \mathrm{MLABe}\right) .{ }^{138}$ Both linear ${ }^{134-136,}$ 138, 139 and cyclic ${ }^{140}$ polymers were produced, depending on the nature of the carbene and on the experimental conditions. To our knowledge, no example of the ROP of MLABe catalyzed by a NHC has been reported.

\subsection{Concluding remarks on the homopolymerization of MLABe}

The ROP of MLABe has been successfully carried out using various ionic initiators/catalysts (Scheme 15). However, the overall performances varied from one class of initiating systems to another. Generally, cationic and (purely) anionic initiators required long reaction times that inherently favor undesirable side reactions (intermolecular and intramolecular transesterification and chain transfer reactions), thus limiting the overall control of the polymerization in terms of molar mass (non predictable) and in the living characteristics of the ROP. On the other hand, nucleophilic catalysts (metal-based or metal-free ones) operating through a nowadays well-established ROP mechanism (coordination-insertion or activated monomer, respectively) afforded much better controlled as well as living polymerizations, thus 
allowing the preparation of well-defined PMLABes and opening the route to copolymers. Improvements in terms of catalytic activity and polymerization control have thus been achieved through the use of these latter species. In the design of PMLA(Be) intended for biomedical applications, organocatalysts which feature a good efficiency, provide a valuable alternative to metal catalytic systems. In comparison to the extended studies on the ROP of other lactones, including of the related BL, the ROP of MLABe remains underdeveloped thus leaving the field wide-opened to further investigations to possibly unveil unprecedented performances of original initiating systems.

\section{Scheme 15. ROP of MLABe mediated by the various catalysts/initiators}

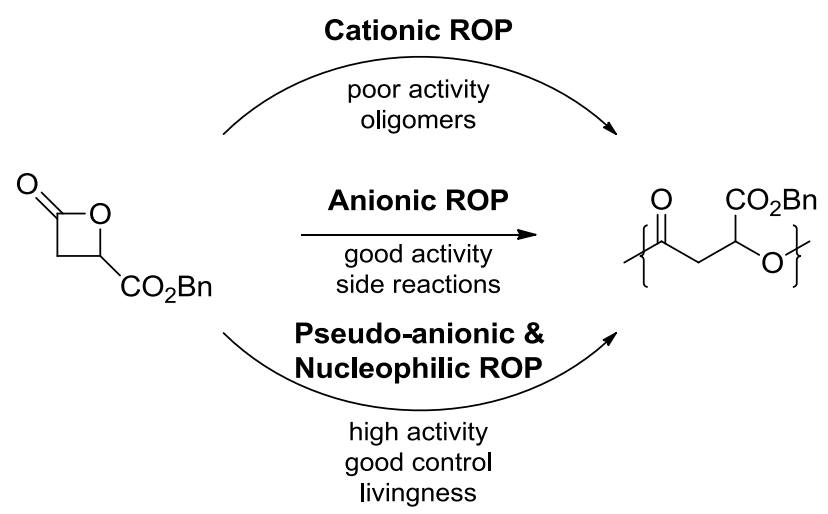

Most of the data reported in the literature concern the ROP of rac-MLABe. Although sparingly investigated, the ROP of MLABe enantiomers enabled the synthesis of PMLABe with different microstructures (atactic, isotactic or stereopolymers), differentiated by their thermal properties. ${ }^{71,115}$ In this regard, the future will certainly be aimed at controlling the PMLABe microstructure through the use of stereoselective catalysts (as developed for instance with BL), ${ }^{141,} 142$ to ultimately tune the thermo-mechanical properties of the MLABe (co)polymers, and subsequently of MLABe-based polymeric materials.

\section{Copolymerization of MLABe}


The design and synthesis of MLABe-based copolymers and subsequently of MLA-related copolymers, have been investigated so as to improve the chemical, biological and physical properties of PMLABe and PMLA. Most of the efforts have been aimed at formulating a polyester material more suitable for a targeted biomedical application upon modulating the characteristics such as the crystallinity, the thermal transition temperatures (glass transition ( $\left.T_{\mathrm{g}}\right)$, melting $\left(T_{\mathrm{m}}\right)$, crystallisation $\left(T_{\mathrm{c}}\right)$, or degradation $\left(T_{\mathrm{d}}\right)$ temperatures $)$, the degradation profile and degradation products, the cytotoxicity, or the viability toward cell activity, of the constituting polymer segments. Indeed, besides the possibility to modify some of these features of the PMLABe via the tuning of its final microstructure through the use of an appropriate selective initiating system in the homopolymerization procedure, macromolecular engineering is a common approach enabling to modulate the characteristics of a given polymer. This allows introduction of various functionalities, along the backbone chain or as pending groups, which subsequently modify the copolymer properties. Also, many PMLABe copolymers have been developed with the objective to obtain, following the hydrogenolysis of the benzyl groups of the PMLABe segment, copolymers of PMLA thus offering variable degrees of carboxylic acid functionality, and consequently widening the range of opportunities there from. These pendant $-\mathrm{CO}_{2} \mathrm{H}$ groups distributed along the polyester backbone then provide hydrophilicity to the resulting PMLA, a feature mainly exploited in the design of amphiphilic self-assembling PMLA-based copolymers. Whereas several $\beta$-lactones have been copolymerized with MLABe such as other alkyl malolactonates (MLARs), $\beta$-butyrolactone (BL), or $\beta$-propiolactone (PL), copolymers derived from MLABe and other lactones (essentially $\varepsilon$-caprolactone (CL)), or diesters (only lactides (LA)) are comparatively more limited. In this regard, the recent achievements towards the controlled and living ROP of MLABe described above are certainly a key factor toward the successful synthesis and diversification of PMLA(Be) copolymers 


\subsection{Copolymerization of MLABe with other alkyl $\beta$-malolactonates}

The class of benzyl $\beta$-malolactonate copolymers with other alkyl $\beta$-malolactonates (MLARs, Table 1) has been quite extensively developed, in particular by Chiellini and co-workers and Guérin and co-workers (Table 7). Various lateral groups have been selected with the objective to ultimately design a large range of PMLAR materials exhibiting diversified characteristics and possible biological recognition. In particular the studies have been aimed at preparing polymers with a specific hydrophobic/hydrophilic balance or with a tunable stability/degradation rate.

Table 7. Copolymers of MLABe and other alkyl $\beta$-malolactonates: operating conditions and copolymers molecular characteristics

\begin{tabular}{|c|c|c|c|c|}
\hline Copolymer & $\begin{array}{c}\text { Initiator/catalyst } \\
\text { (Solvent, reaction } \\
\text { temperature, reaction time) }\end{array}$ & $\begin{array}{c}M_{\mathrm{w}} \text { or } M_{\mathrm{n}} \\
\text { (SEC solvent, } \\
\text { temperature, } \\
\text { standards) }\end{array}$ & $\boldsymbol{Ð}_{\mathbf{M}}$ & Ref. \\
\hline $\mathrm{P}(\mathrm{MLABe}-b-\mathrm{MLABu})$ & $\begin{array}{l}\text { KAc/(DB-18-C-6, cryptand } \\
\text { [222], TEABz or TMABz } \\
\left(\mathrm{CH}_{2} \mathrm{Cl}_{2}, \mathrm{THF}, \text { bulk, }\right. \\
20-60{ }^{\circ} \mathrm{C}, 26-72 \mathrm{~h} \text { for the } \\
\text { first monomer - unspecified } \\
\text { for copolymerization) }\end{array}$ & $\begin{array}{c}M_{\mathrm{n}} 86000-110000 \\
(-,-, \text { osmometry and } \\
\text { differential } \\
\text { refractometry/viscosity) }\end{array}$ & (bimodal) & 61 \\
\hline $\begin{array}{c}\text { P(MLABe- } b \text {-MLABu) } \\
\text { P(MLABe- } b-\mathrm{MeMLABu})\end{array}$ & $\begin{array}{l}\text { KNaphtalide/18-C-6 } \\
\left.\text { (THF, } 40^{\circ} \mathrm{C},-\right)\end{array}$ & $\begin{array}{l}M_{\mathrm{n}, \mathrm{NMR}} 1000-3000 \\
\quad(\mathrm{THF},-, \mathrm{PS})\end{array}$ & - & 84,85 \\
\hline $\mathrm{P}(\mathrm{MLABe}-\mathrm{co}-\mathrm{MLABu})$ & $\begin{array}{c}\text { TEABz } \\
\text { (bulk, } 37-70^{\circ} \mathrm{C}, 3 \mathrm{~d} \text { ) }\end{array}$ & $\begin{array}{c}M_{\mathrm{p}} 85000 \\
\text { (Dioxane, -, PS) }\end{array}$ & & 78,103 \\
\hline $\begin{array}{l}\mathrm{P}(\mathrm{MLABe}-\mathrm{co}-\mathrm{MLAR}) \\
\mathrm{R} \text { : refer to Table } 2\end{array}$ & $\begin{array}{c}\text { TEABz } \\
\text { (THF, bulk, 38-42 }{ }^{\circ} \text {, } \\
4-31 \mathrm{~d} \text { ) }\end{array}$ & $\begin{array}{c}M_{\mathrm{n}} 2700-9900 \\
\left(\mathrm{CHCl}_{3}, 25^{\circ} \mathrm{C}, \mathrm{PS}\right)\end{array}$ & $\begin{array}{l}1.15-1.73 \\
\text { (bimodal) }\end{array}$ & 89,143 \\
\hline $\mathrm{P}(\mathrm{MLABe}-\mathrm{co}-\mathrm{MLAOct})$ & $\begin{array}{c}\text { Betaine } \\
\text { (bulk, } 40{ }^{\circ} \mathrm{C}, 8 \mathrm{~d} \text { ) }\end{array}$ & $\begin{array}{c}M_{\mathrm{n}} 1600-17100 \\
(-,-,--)\end{array}$ & $1.3-2.8$ & 86 \\
\hline P(MLABe-co-MLAAll) & $\begin{array}{c}\text { KHDD } / 18-\mathrm{C}-6 \\
\left(\mathrm{THF}, 0{ }^{\circ} \mathrm{C}, 4.3 \mathrm{~h}\right)\end{array}$ & $\begin{array}{c}M_{\mathrm{n}, \mathrm{NMR}} 8100-8400 \\
\left(\mathrm{THF}, 35^{\circ} \mathrm{C}, \mathrm{PS}\right)\end{array}$ & $1.2-1.5$ & 106,144 \\
\hline P(MLABe-co-MLAEAd) & $\begin{array}{c}\text { TEABz } \\
\text { (bulk, } 40^{\circ} \mathrm{C}, 7 \mathrm{~d} \text { ) }\end{array}$ & $\begin{array}{c}M_{\mathrm{n}} 19500-40600 \\
(\mathrm{THF},-, \mathrm{PS})\end{array}$ & $1.6-1.9$ & $\begin{array}{c}91,103,144, \\
145\end{array}$ \\
\hline
\end{tabular}

-: not reported 
First, amphiphilic copolymers featuring PMLABe and PMLA segments have been prepared upon partial hydrogenolysis of PMLABe prepolymers. The experimental conditions have a significant impact on the extent of the reaction; depending on the solvent, the catalyst, and the reaction temperature, mixtures of homopolymers and/or copolymers may be obtained. The simple effective reduction of the benzyl groups is nowadays typically carried out in acetone at $25{ }^{\circ} \mathrm{C}$ over a few hours in presence of $\mathrm{Pd} /$ charcoal under hydrogen pressure. These mild conditions do not alter the polymer backbone. ${ }^{146-148}$ Guérin and co-workers have shown, by comparing the carbonyl NMR resonances of copolymers with different comonomer sequence distribution using selective insensitive nuclei enhanced by polarization transfer (INEPT) technique, that partial hydrogenolysis of PMLABe affords PMLABe- $b$-PMLA block copolymers. ${ }^{149}$ Also, the various PMLABe copolymers and terpolymers described in the present review and featuring diverse polyester/polycarbonate as other segment(s), have been almost all systematically hydrogenolyzed under similar mild operating conditions to access the parent PMLA copolymers and terpolymers, respectively. Note that the hydrophobic/hydrophilic PMLABe/PMLA couple is reminiscent of the poly $(\gamma$-glutamic acid) (PGA)/poly $(\gamma$-benzyl Lglutamate) (PBLG) polypeptides also widely explored for biomedical applications. ${ }^{150,151}$

Both block $^{61,84,85}$ and random ${ }^{78,152}$ copolymers derived from MLABe and racemic butyl $\beta$-malolactonate (MLABu) or racemic butyl 3-methyl $\beta$-malolactonate (MeMLABu) have been developed. Block copolymers of MLABe and MLABu were prepared form the sequential anionic ROP of the comonomers using potassium acetate and a complexing agent (DB18-C-6, or cryptand [222], or tetraethyl- or tetramethyl-ammonium benzoate (TEABz and TMABz, respectively)) as initiator, whichever the order of monomer addition. ${ }^{61}$ However, due to the presence of transesterification reactions inherent to the operating conditions (a carboxylatebased catalytic system, high reaction temperature and long reaction time), the $\mathrm{P}(\mathrm{MLABe}-b$ MLABu) were recovered as a mixture with the homopolymer of the first added $\beta$-lactone. ${ }^{61}$ 
Also, PMLABe end-capped by a carboxylic acid group was first synthesized by anionic ROP mediated by the potassium naphtalide/18-C-6 catalytic system and next used as initiator in the anionic ROP of the second $\beta$-lactone, MLABu or MeMLABu. ${ }^{84,85}$ The reaction was monitored by FTIR and stopped after disappearance of the characteristic lactone $v_{\mathrm{C}=\mathrm{O}}$ band at $1850 \mathrm{~cm}^{-1}$ evidencing the complete consumption of the lactone. ${ }^{1} \mathrm{H}$ NMR analyses of the P(MLABe- $b$ $\mathrm{MLABu})$ and $\mathrm{P}(\mathrm{MLABe}-b-\mathrm{MeMLABu})$ copolymers confirmed their structure. SEC measurements allowed to evaluate the molar mass of the second block formed which was however found lower than that of the PMLABe prepolymer, as rationalized by the occurrence of significant chain transfer reactions. Degradable macromolecular micelles were next prepared from the deprotected PMLA parent block copolymers. ${ }^{84,85}$

Random P(MLABe-co-MLABu) copolymers were first, yet briefly, described by Guérin and co-workers ${ }^{78}$ and Cammas and co-workers. ${ }^{103}$ The copolymer was unusually soluble in diethyl ether and displayed a $T_{\mathrm{g}}$ value $\left(-50{ }^{\circ} \mathrm{C}\right)$ lower than that of PMLABe $\left(+37^{\circ} \mathrm{C} ; M_{\mathrm{n}}=\right.$ 10000 g.mol $\left.{ }^{-1}\right) \cdot{ }^{80}$ Evidence for a random distribution of repeating units was shown by ${ }^{13} \mathrm{C}$ NMR structural analysis. Also, in their work on P(MLABe-co-MLABu), Davies and coworkers investigated the surface chemical structure of $\mathrm{P}(\mathrm{MLABe}-\mathrm{co}-\mathrm{MLABu})$ by X-ray photoelectron spectroscopy (XPS) and ToF-SIMS analyses. ${ }^{152}$ XPS data revealed a good correlation between the experimental and theoretical compositions while the ToF-SIMS measurements of these materials showed the characteristic and expected fragmentation patterns.

Chiellini and co-workers developed a family of alkyl $\beta$-malolactonate to be copolymerized with MLABe. ${ }^{89}, 143$ The goal was to elaborate highly bioactive degradable polymers which could be used as minor components of poly(2-hydroxyethyl methacrylate) (PHEMA)-based semi-interpenetrating networks for tissue engineering applications. Functionalization of the lateral chain of the malic residue was performed through esterification with several readily available alcohols (Table 2), so as to either significantly improve the 
hydrophobicity, to target some specific biological in vivo recognition of natural terpene structures, or to provide reactive sites for further functionalization. The copolymers were synthesized from the simultaneous anionic ROP of the corresponding monomers in the presence of a quaternary ammonium (TEABz) salt as initiator (41-85\% yield). Adjusting the comonomer feed ratio enabled to tune the hydrophobicity of the P(MLABe-co-MLAR), or to tune the number of functionalizable moieties introduced along the polymer chain. The copolymers composition, as determined from ${ }^{1} \mathrm{H}$ NMR spectra, was close to the feed mixture (no chain-end identification was yet reported). The thermal oligomerization of the copolymers with an acrylic side-chain was not observed by NMR and SEC analyses, thus highlighting the stability of these groups. All copolymers displayed $T_{\mathrm{g}}$ values as determined by DSC ranging from 1 to $42{ }^{\circ} \mathrm{C}$, in agreement with the Couchman-Fox equation.

Dubois and co-workers prepared random copolymers of MLABe and allyl $\beta$-malolactonate (MLAAll) through a simultaneous anionic copolymerization promoted by KHDD/18-C-6. ${ }^{106}$ The resulting P(MLABe-co-MLAAll) copolymers were then $\alpha$-hydroxy, $\omega$ carboxylic acid end-capped and exhibited pendant allylic functions. The copolymers composition, as determined by ${ }^{1} \mathrm{H}$ NMR analysis, fairly matched the one expected from the feed ratio of comonomers and the molar mass values measured by SEC were only slightly lower than the expected ones while the dispersity remained below 1.5. These random copolymers were next modified at their allylic functions by a radical reaction with mercaptoethanol in the presence of AIBN at $70{ }^{\circ} \mathrm{C}$, into hydroxy groups, subsequently used as initiating sites for the ROP of CL, ultimately affording P(MLA-g-CL) (vide infra).

Such P(MLABe-co-MLAAll) were also prepared by Cammas-Marion and Guérin from the anionic ROP mediated by $\mathrm{TEABz}$, and further reacted with dimethyldioxirane or metachloroperbenzoic acid (MCPBA) in dichloromethane to form the parent copolymers with pendant reactive epoxide groups allowing further chemical modifications. ${ }^{144}$ Starting from 
MLABe, MLAAll and 3-methyl-3-butenyl malolactonate, terpolymers were thus prepared and chemically modified in polymers eventually evaluated as heparan sulfate-like materials. The synthesis and characterization of these copolymers however lacked additional details.

Bulky ethyladamantyl malolactonate (MLAEAd) and MLABe have also been copolymerized by Cammas and co-workers leading to P(MLABe-co-MLAEAd) displaying $T_{\mathrm{g}}$ values varying $\left(20-50{ }^{\circ} \mathrm{C}\right)$ with the adamantly content (4-100\%, respectively), while the parent P(MLA-co-MLAEAd) featured a $T_{\mathrm{g}}$ at $70{ }^{\circ} \mathrm{C} .{ }^{91,103,144,145}$ The resulting P(MLA-co-MLAEAd) copolymer obtained after hydogenolysis of the parent PMLABe copolymer precursor is particularly interesting due to its water solubility and to the simultaneous presence of lateral carboxylic acid functions and adamantly groups. The mixture in aqueous solution of the parent

PMLA copolyester with $10 \%$ of adamantly groups and a $\beta$-cyclodextrin/epichlorohydrin copolymer gave a $\mathrm{pH}$-dependant associating system. The study showed that the adamantly groups are accessible and that they can be encapsulated into the $\beta$ cyclodextrin cavities.

A copolymer of MLABe and octyl $\beta$-malolactonate (MLAOct) has been prepared upon simultaneous ROP of the comonomers mediated by betaine over eight days at $40{ }^{\circ} \mathrm{C}$, as reported by Osanai and co-workers. ${ }^{86}$ The resulting P(MLABe-co-MLAOct) was next debenzylated into P(MLA-co-MLAOct) in which the octyl groups served as anchors at the surface of liposomes. Aggregation and leakage behaviors were then studied.

\subsection{Copolymerization of MLABe with $\beta$-propiolactone and $\beta$-butyrolactone}

Besides these copolymers featuring segments derived from various alkyl $\beta$-malolactonates, copolymers of MLABe have also been prepared from two other four membered-ring $\beta$-lactones, namely $\beta$-propiolactone (PL) and $\beta$-butyrolactone (BL, Table 8). 
Table 8. Copolymers of MLABe and $\beta$-lactones (PL, BL): operating conditions and copolymers molecular characteristics

\begin{tabular}{|c|c|c|c|c|}
\hline Copolymer & $\begin{array}{c}\text { Initiator/Catalyst } \\
\text { (Solvent, reaction temperature, } \\
\text { reaction time) }\end{array}$ & $\begin{array}{l}M_{\mathrm{w}} \text { or } M_{\mathrm{n}} \\
\text { (SEC solvent, } \\
\text { temperature, } \\
\text { standards) }\end{array}$ & $\bigoplus_{M}$ & Ref. \\
\hline $\mathrm{P}(\mathrm{MLABe}-c o-\mathrm{PL})$ & $\begin{array}{c}\text { Candida Cylindracea lipase } \\
\left.\text { (bulk, } 40-60^{\circ} \mathrm{C}, 1 \mathrm{~d}\right)\end{array}$ & $\begin{array}{c}M_{\mathrm{w}} 7300-32100 \\
\left(\mathrm{CHCl}_{3}, 25^{\circ} \mathrm{C}, \mathrm{PS}\right)\end{array}$ & $1.2-1.6$ & 54 \\
\hline $\mathrm{P}(\mathrm{MLABe}-c o-\mathrm{BL})$ & $\begin{array}{c}\text { Candida Cylindracea lipase } \\
\text { (bulk, } 40^{\circ} \mathrm{C}, 7 \mathrm{~d} \text { ) }\end{array}$ & $\begin{array}{c}M_{\mathrm{w}} 4300 \\
\left(\mathrm{CHCl}_{3}, 25^{\circ} \mathrm{C}, \mathrm{PS}\right)\end{array}$ & 1.1 & 54 \\
\hline $\mathrm{P}(\mathrm{MLABe}-c o-\mathrm{BL})$ & $\begin{array}{c}\text { EAO, MAO, IBAO } \\
\text { (heptane, toluene, } 60^{\circ} \mathrm{C}, 27 \mathrm{~d} \text { ) }\end{array}$ & $\begin{array}{c}M_{\mathrm{n}} 11000-120000 \\
\left(\mathrm{CHCl}_{3}, 25^{\circ} \mathrm{C}, \mathrm{PS}\right)\end{array}$ & $4.3-19.0$ & $\begin{array}{c}115,153, \\
154\end{array}$ \\
\hline $\mathrm{P}(\mathrm{MLABe}-c o-\mathrm{BL})$ & $\begin{array}{c}\mathrm{ZnEt}_{2} / \mathrm{H}_{2} \mathrm{O} \\
\text { TPPAlCl } \\
\text { (bulk, } 60^{\circ} \mathrm{C}, 14-80 \mathrm{~d} \text { ) } \\
\end{array}$ & $\begin{array}{c}M_{\mathrm{n}} 5000-26000 \\
\left(\mathrm{CHCl}_{3}, 25^{\circ} \mathrm{C}, \mathrm{PS}\right)\end{array}$ & $1.33-1.80$ & 153 \\
\hline $\mathrm{P}(\mathrm{MLABe}-c o-\mathrm{BL})$ & $\begin{array}{c}\mathrm{Nd}(\mathrm{OTf})_{3} /{ }^{i} \mathrm{PrOH} \\
\text { (bulk, 60, 96h) }\end{array}$ & $\begin{array}{c}M_{\mathrm{n}, \mathrm{NMR}} 3300-5800 \\
\left(\mathrm{THF}, 25^{\circ} \mathrm{C}, \mathrm{PS}\right) \\
\end{array}$ & 1.40 & 118 \\
\hline $\mathrm{P}(\mathrm{MLABe}-b-\mathrm{BL})$ & $\begin{array}{c}{\left[(\mathrm{BDI}) \mathrm{Zn}\left\{\mathrm{N}\left(\mathrm{SiMe}_{3}\right)_{2}\right\}\right] /{ }^{i} \mathrm{PrOH},} \\
\mathrm{Nd}(\mathrm{OTf})_{3} /{ }^{\mathrm{PrOH}}, \\
\mathrm{TBD}, \mathrm{DBU}, \mathrm{BEMP} \\
\text { (bulk, 60, 0.5-48h) }\end{array}$ & $\begin{array}{l}M_{\mathrm{n}, \mathrm{NMR}} 1700-73500^{*} \\
\quad\left(\mathrm{THF}, 25^{\circ} \mathrm{C}, \mathrm{PS}\right)\end{array}$ & $1.13-1.46$ & 118 \\
\hline $\begin{array}{l}\text { PLLA- } b-\mathrm{P}\left(\mathrm{Me}_{2} \mathrm{MLABe}-c o-\right. \\
\text { BL)- } b \text {-PLLA }\end{array}$ & $\begin{array}{l}\text { 1,3,4-triphenyl-4,5-dihydro- } 1 \mathrm{H} \text { - } \\
\text { 1,2,4-triazol-5-ylidene carbene/ } \\
\quad \text { ethylene glycol } \\
\text { (toluene } / t \text {-BuOH, } 80{ }^{\circ} \mathrm{C}, 48 \mathrm{~h} \text { - } \\
\text { diblock; } 90{ }^{\circ} \mathrm{C}, 16 \mathrm{~d} \text {-tribloc) }\end{array}$ & $\begin{array}{l}M_{\mathrm{n}, \mathrm{NMR}} 7300-11200 \\
\quad(\text { diblock) } \\
M_{\mathrm{n}, \mathrm{NMR}} 7100 \text { (triblock) } \\
\quad\left(\mathrm{THF}, 35^{\circ} \mathrm{C}, \mathrm{PS}\right)\end{array}$ & $\begin{array}{c}1.09-1.27 \\
\text { (diblock) } \\
1.38 \\
\text { (triblock) }\end{array}$ & 138 \\
\hline
\end{tabular}

* The signals corresponding to the organobase hydrogens correspond to a significant number of hydrogens in the initiator and emerge well from the spectrum baseline, thus allowing the reliable determination of the molar mass by NMR analysis.

In their attempts to homopolymerize rac-MLABe by the Candida Cylindracea lipase, Matsumura and co-workers observed that the addition of PL (17 mol\%) mediated the reaction (faster rate, lower operating temperature, higher PMLABe molar mass and yield). ${ }^{54}$ This enzyme-catalyzed ROP of MLABe with PL carried out at $40{ }^{\circ} \mathrm{C}$ (a temperature at which MLABe fails to homopolymerize under the same conditions) in bulk over one day, thus afforded $\mathrm{P}\left(\mathrm{MLABe}-\mathrm{co}\right.$-PL). Formation of the copolymer was supported by ${ }^{13} \mathrm{C}$ NMR analysis showing peaks corresponding to the adjacent monomer sequences of MLABe and PL. Note that the similar addition of BL in the ROP of MLABe only afforded PMLABe. 
In 1988, Gross and co-workers copolymerized rac-MLABe and rac-BL by using ethylaluminoxane (EAO) and methylaluminoxane (MAO) initiators pre-isolated from the reaction of $\mathrm{Et}_{3} \mathrm{Al}$ and $\mathrm{Me}_{3} \mathrm{Al}$ with $\mathrm{H}_{2} \mathrm{O}$, respectively. ${ }^{115}$ Copolymers were recovered in $10-27 \%$ yield after 27 days of reaction with a good match between the feed ratio and the copolymer composition. The acetone-soluble fraction contained copolymers with lower $M_{\mathrm{n}}$ values (up to $29000 \mathrm{~g} \cdot \mathrm{mol}^{-1}$ ) as compared to those recovered within the acetone-insoluble fraction (up to 120000 g.mol $\left.{ }^{-1}\right)$. A somewhat statistically random distribution of the comonomers was evidenced from DSC and ${ }^{1} \mathrm{H}$ and ${ }^{13} \mathrm{C}$ NMR data, the latter also highlighting the comonomer diad sequence distributions. ${ }^{115}$ The investigations enlarged to other alkyl aluminoxane catalysts, similarly showed that EAO and triisobutylaluminum (IBAO) also afforded P(MLABe-co-BL) copolymers, as reported by Benvenuti and Lenz ${ }^{154}$ and Zhang and Lenz. ${ }^{153}$ The copolymers were then recovered in higher yield (43-72\%) from IBAO and were shown $\left({ }^{1} \mathrm{H}\right.$ and ${ }^{13} \mathrm{C} \mathrm{NMR}$, DSC analyses) to have a stereoblock isotactic $(84-87 \%)^{154}$ or random atactic ${ }^{153}$ structure, depending on the catalyst system. Random atactic P(MLABe-co-BL) copolymers were also prepared from $\mathrm{ZnEt}_{2} / \mathrm{H}_{2} \mathrm{O}(0.6: 1)$ and $\mathrm{TPPAlCl}$ with improved yields $(\leq 98 \%)$, yet with lower molar mass values and a poorer control. ${ }^{115}$

In some recent work, Guillaume and co-workers identified some similar initiating systems able to ring-open polymerize both MLABe and BL, namely the zinc $\beta$-diketiminate amido complex $\left[(\mathrm{BDI}) \mathrm{Zn}\left\{\mathrm{N}\left(\mathrm{SiMe}_{3}\right)_{2}\right\}\right] / \mathrm{ROH}\left(\mathrm{R}={ }^{i} \mathrm{Pr}, \mathrm{Bn}\right)$, the neodymium triflate $/{ }^{i} \mathrm{PrOH}$, and the organic bases such as TBD, DBU or BEMP. ${ }^{118}$ These homopolymerization results allowed to further consider copolymerization investigations. The simultaneous copolymerization of MLABe and BL mediated by the zinc-based system (in the presence of ${ }^{i} \mathrm{PrOH}$ ) only afforded PMLABe, leaving BL unreacted. On the other hand, the sequential copolymerization with this same zinc system proceeded effectively only when BL was introduced prior to MLABe, providing $\mathrm{P}(\mathrm{MLABe}-b$ - $\mathrm{BL})$ copolymers. Also, in a simultaneous copolymerization approach, 
while the $\mathrm{Nd}(\mathrm{OTf})_{3} / \mathrm{PrOH}$ catalyst system (and only this system) enabled the synthesis of $\mathrm{P}(\mathrm{MLABe}-$ ran-BL) random copolymers, $\mathrm{P}(\mathrm{MLABe}-b-\mathrm{BL})$ block copolymers could be obtained from the basic BEMP. All systems considered, [(BDI)Zn $\left.\left\{\mathrm{N}\left(\mathrm{SiMe}_{3}\right)_{2}\right\}\right] /{ }^{i} \mathrm{PrOH}$, $\mathrm{Nd}(\mathrm{OTf})_{3} /{ }^{i} \mathrm{PrOH}, \mathrm{TBD}, \mathrm{DBU}$ or BEMP, afforded block copolymers upon sequential copolymerization of the comonomers. Thus, BEMP was shown to give $\mathrm{P}(\mathrm{MLABe}-b-\mathrm{BL})$ from either a simultaneous or a sequential approach and regardless of the order of the comonomers addition. Well-defined high molar mass copolymers $\left(M_{\mathrm{n}, \mathrm{NMR}}\right.$ up to $73500 \mathrm{~g} \cdot \mathrm{mol}^{-1}$ with $\bigoplus_{\mathrm{M}}=$ 1.44) were thus prepared with good conversions of monomers within reasonable reaction times $(<48 \mathrm{~h})$ for $\mathrm{P}(\mathrm{MLABe}-b-\mathrm{BL})$, and yet longer $(96 \mathrm{~h})$ for $\mathrm{P}(\mathrm{MLABe}-c o-\mathrm{BL})$. Interestingly, the possibility to achieve the kinetic and microstructure control in the copolymerization of MLABe and $\mathrm{BL}$ via catalytic tuning was also evidenced, especially from ${ }^{1} \mathrm{H}$ and ${ }^{13} \mathrm{C}$ NMR, SEC and DSC analyses.

Finally, the metal-free, $N$-heterocyclic carbene/ethylene glycol catalyzed ROP of the dimethyl MLABe (Me 2 MLABe,4-benzyloxycarbonyl-3,3-dimethyl-2-oxetanone) and BL afforded $\alpha, \omega$-dihydroxy $\mathrm{P}\left(\mathrm{Me}_{2} \mathrm{MLABe}-\mathrm{co}\right.$-BL) which were subsequently used as difunctional macroinitiator in (L,L)-lactide (LLA) ROP, to ultimately give the triblock copolymers, PLLA$b$-P(Me 2 MLABe-co-BL)- $b$-PLLA. ${ }^{138}$ In this work by Dubois and co-workers, the ethylene glycol initiator combined to the commercially available triazole carbene (1,3,4-triphenyl-4,5dihydro-1H-1,2,4-triazol-5-ylidene carbene) catalyst were found poorly active. The copolymerization was rather slow, affording the diblock copolymers with almost quantitative yield in 2 days at $80{ }^{\circ} \mathrm{C}$, whereas the triblock analogues were only obtained after ca. 16 days at $90{ }^{\circ} \mathrm{C}$. $\mathrm{Me}_{2} \mathrm{MLABe}$ was shown by ${ }^{1} \mathrm{H}$ NMR studies to be preferentially incorporated in the growing copolyester chain. The triblock copolymer was next reduced by hydrogenolysis to afford the corresponding amphiphilic PLLA- $b$-PMe ${ }_{2}$ MLA- $b$-PLLA copolymers, next shown to 
exhibit a temperature reversible gel-sol transition of microgels to primary "flower" like micelles.

\subsection{Copolymerization of MLABe with $\varepsilon$-caprolactone}

In addition to the copolymers of MLABe with all the $\beta$-lactones previously mentioned, the only other lactone which, to our knowledge, has been copolymerized with MLABe is $\varepsilon$-caprolactone (CL), thereby affording both diblock and triblock copolymers of different topologies (block, random or graft) (Table 9).

Table 9. Copolymers of MLABe and CL: operating conditions and copolymers molecular characteristics

\begin{tabular}{|c|c|c|c|c|}
\hline Copolymer & $\begin{array}{c}\text { Initiator/catalyst } \\
\text { (Solvent, reaction temperature, } \\
\text { reaction time) }\end{array}$ & $\begin{array}{c}M_{\mathrm{w}} \text { or } M_{\mathrm{n}} \\
\text { (SEC solvent, } \\
\text { temperature, } \\
\text { standards) }\end{array}$ & $\boldsymbol{Ð}_{\mathbf{M}}$ & Ref. \\
\hline $\mathrm{P}(\mathrm{MLABe}-b-\mathrm{CL})$ & $\begin{array}{l}\mathrm{AlEt}_{3}, \mathrm{HO}-\mathrm{PMLABe}-\mathrm{CO}_{2} \mathrm{Me} \\
\text { (Toluene, } \mathrm{RT}, 48 \mathrm{~h} \text { ) }\end{array}$ & $\begin{array}{c}M_{\mathrm{n}, \mathrm{NMR}} 19400 \\
\left(\mathrm{THF}, 35^{\circ} \mathrm{C}, \mathrm{PS}\right)\end{array}$ & 1.51 & $\begin{array}{c}80,104 . \\
107\end{array}$ \\
\hline $\mathrm{P}(\mathrm{CL}-b-\mathrm{MLABe}-b-\mathrm{CL})$ & $\begin{array}{c}\mathrm{AlEt}_{3}, \text { PMLABe-diol } \\
\text { (Toluene, RT, } 64 \mathrm{~h} \text { ) }\end{array}$ & $\begin{array}{c}M_{\mathrm{n}, \mathrm{NMR}} 15300 \\
\left(\mathrm{THF}, 35^{\circ} \mathrm{C}, \mathrm{PS}\right)\end{array}$ & 1.50 & 105 \\
\hline $\begin{array}{l}\text { s[PCL- } b \text {-PEG- } b- \\
\text { PMLABe }]\end{array}$ & $\begin{array}{c}\text { HO-PEG-COOK } / 18-\mathrm{C}-6 \\
\left(\mathrm{THF}, 0^{\circ} \mathrm{C}, 2.8 \mathrm{~h}\right) \\
\text { Sn }(\text { Oct })_{2}\left(\text { toluene, } 80^{\circ} \mathrm{C}, 24 \mathrm{~h}\right)\end{array}$ & $\begin{array}{c}M_{\mathrm{n}, \mathrm{NMR}} 6200 \\
\left(\mathrm{THF}, 45^{\circ} \mathrm{C}, \mathrm{PS},\right. \\
\text { PEG) }\end{array}$ & 1.50 & 108 \\
\hline $\mathrm{P}(\mathrm{MLABe}-c o-\mathrm{CL})$ & $\begin{array}{c}\operatorname{Sn}(\mathrm{Oct})_{2} \\
\left.\text { (bulk, } 130{ }^{\circ} \mathrm{C}, 24 \mathrm{~h}\right)\end{array}$ & $\begin{array}{l}M_{\mathrm{n}} 2900-20600 \\
\left(\mathrm{THF}, 25^{\circ} \mathrm{C}, \mathrm{PS}\right)\end{array}$ & $1.30-1.97$ & 155 \\
\hline $\begin{array}{c}\text { H40-P(MLABe-co-CL) } \\
\text { H40-P(MLABe-co-CL)- } \\
b \text {-MPEG/-PEG-FA }\end{array}$ & $\begin{array}{l}\mathrm{Sn}(\mathrm{Oct})_{2} / \text { Boltron } \mathrm{H} 40-(\mathrm{OH})_{64} \\
\left.\quad \text { (bulk, } 110^{\circ} \mathrm{C}, 24 \mathrm{~h}\right)\end{array}$ & $\begin{array}{c}M_{\mathrm{n}} 76500(\text { diblock } \\
\text { copolymer) } \\
M_{\mathrm{n}} 115500(\mathrm{PEG} \\
\text { copolymers) } \\
\left(\mathrm{THF}, 25^{\circ} \mathrm{C}, \mathrm{PS}\right)\end{array}$ & $\begin{array}{c}1.64 \text { (diblock } \\
\text { copolymer) } \\
1.42 \text { (PEG } \\
\text { copolymers) }\end{array}$ & 81 \\
\hline $\mathrm{P}(\mathrm{MLABe}-\mathrm{g}-\mathrm{CL})$ & $\begin{array}{c}\text { KHDD/18-C-6 } \\
\left(\mathrm{THF}, 0^{\circ} \mathrm{C}, 3.5 \mathrm{~h}-\mathrm{RT}, 20.5 \mathrm{~h}\right)\end{array}$ & $\begin{array}{l}M_{\mathrm{n}} 2000-6300 \\
\left(\mathrm{THF}, 35^{\circ} \mathrm{C}, \mathrm{PS}\right)\end{array}$ & $1.3-2.3$ & 106 \\
\hline $\begin{array}{l}\text { P(MLABe-co-MLAAll)- } \\
g \text {-CL) }\end{array}$ & $\begin{array}{c}\mathrm{KHDD} / 18-\mathrm{C}-6 \\
\left(\mathrm{THF}, 0^{\circ} \mathrm{C}, 4.3 \mathrm{~h} \text { ) and then }\right. \\
\mathrm{AlEt}_{3}\left(\text { toluene, } 0{ }^{\circ} \mathrm{C}, 72 \mathrm{~h} \text { ) }\right.\end{array}$ & $\begin{array}{l}M_{\mathrm{n}} 3700-14000 \\
\left(\mathrm{THF}, 35^{\circ} \mathrm{C}, \mathrm{PS}\right)\end{array}$ & $1.6-1.8$ & 106 \\
\hline
\end{tabular}

Using $\alpha$-hydroxy, $\omega$-carboxylic acid PMLABe, previously obtained by the anionic ROP of rac-MLABe mediated by KHDD in the presence of 18-C-6, Dubois and co-workers prepared the corresponding $\alpha$-hydroxy, $\omega$-methoxycarbonyl PMLABe upon the selective methylation of 
the carboxylic acid end-group using an excess of trimethylsilyldiazomethane. ${ }^{80,104}$ This latter polymer next served as macroinitiator in the ROP of $\mathrm{CL}$ using $\mathrm{AlEt}_{3}$, thus affording the diblock copolymer $\mathrm{P}\left(\mathrm{MLABe}-b\right.$-CL) with a good theoretical/experimental $\left(M_{\mathrm{n}, \mathrm{NMR}}\right)$ molar mass agreement. This was actually the first report on the combination of the anionic and coordination-insertion ROP of MLABe and CL, respectively. The objective of this briefly described experiment was to next prepare the corresponding amphiphilic P(MLA- $b-\mathrm{CL})$ copolymer upon hydrogenolysis. ${ }^{80}$ This approach was also followed for the synthesis of the analogous $\alpha$-lauryl, $\omega$-methyl PMLABe/PMLA block copolymers upon changing KHDD with potassium laurate in the first MLABe anionic ROP step. ${ }^{107}$ The resulting PMLABe/PMLA copolymers were then studied for their tensioactive properties in aqueous solution.

The related triblock copolymer P(CL- $b$-MLABe- $b-\mathrm{CL})$ has been prepared by Dubois and co-workers by coordination-insertion ROP of CL using $\mathrm{AlEt}_{3}$ and the $\alpha, \omega$-dihydroxy PMLABe macroinitiator. ${ }^{105}$ The PMLABe-diol was previously obtained from the anionic ROP of rac-MLABe mediated by KHDD/18-C-6, followed by the selective reduction by $\mathrm{BH}_{3}$.THF of the carboxylic acid end-group of the thus formed $\alpha$-hydroxy, $\omega$-carboxylic acid PMLABe into a hydroxyl terminus. After hydrogenolysis into the corresponding PMLA triblock amphiphilic copolymer, the critical micelle concentration (CMC) was found higher by one order of magnitude than that of P(MLA- $b-\mathrm{CL})$ of similar composition, as a result of the entropic penalty for bending the PMLA central block to produce flower-like micelles.

Triblock copolymers incorporating PMLABe, PCL and PEG segments have been reported by Jérôme and co-workers. ${ }^{108}$ Each constituting arm of these amphiphilic miktoarm ABC star-shaped copolymers, s[PCL- $b$-PEG- $b$-PMLABe], was prepared by ROP. An $\alpha, \alpha^{\prime}-$ heterobifunctional PEG macroinitiator was first designed with a potassium carboxylate endfunction and a hydroxyl group, HO-PEG-COOK, which successively and selectively initiated the anionic ROP of rac-MLABe, and the coordination-insertion ROP of CL in the presence of 
$\mathrm{Sn}(\mathrm{Oct})_{2}$, respectively. Note that prior to the ROP of CL, the carboxylic acid terminal group of the PEG- $b$-PMLABe diblock copolymer was esterified by trimethylsilyldiazomethane to give HO-PEG- $b$-PMLABe-COOMe next used as a macroinitiator. The various steps of the overall synthesis of the triblock copolymers were carefully monitored by ${ }^{1} \mathrm{H}$ NMR, FTIR, SEC and MALDI-ToF mass spectrometry analyses in a complete study.

The simultaneous copolymerization of $r a c$-MLABe and CL was successfully carried out by Chan-Park and He to design some functionalizable and photopatternable biodegradable copolymers. ${ }^{155}$ The ROP of the comonomers was mediated by $\mathrm{Sn}(\mathrm{Oct})_{2}$ only $\left(\mathrm{Sn}(\mathrm{Oct})_{2}\right.$ is said to catalyze but not to initiate the reaction; yet, the initiator is not specified) at the optimized temperature of $130{ }^{\circ} \mathrm{C}$. Liquid random copolymers $\mathrm{P}(\mathrm{MLABe}-\mathrm{co}-\mathrm{CL})$ with high yields (80-87\%), molar mass values $\left(M_{\mathrm{n}, \mathrm{SEC}}\right.$ up to $\left.20600 \mathrm{~g} \cdot \mathrm{mol}^{-1}\right)$, MLABe content $(100 \%)$, and minimized dispersity values $\left(1.30<\bigoplus_{M}<1.97\right)$ were thus obtained. As a result of the lower reactivity of MLABe vs CL, the amount of MLABe found incorporated into the copolymer remained lower than that anticipated from the initial feed ratio. Both the molar mass and the glass transition temperature decreased with a larger CL segment. After hydrogenolysis, the 2hydroxyethyl methacrylate (HEMA) grafted copolymers were used as a liquid resin for UV microembossing with potential applications in the fabrication of tissue engineering scaffolds.

A random $\mathrm{H} 40-\mathrm{P}(\mathrm{MLABe}-\mathrm{co}-\mathrm{CL})-\mathrm{OH}$ copolymer was also synthesized from the simultaneous ROP of rac-MLABe and CL promoted by $\mathrm{Sn}(\mathrm{Oct})_{2}$ catalyst, using a hyperbranched aliphatic polyester, Boltron H40, bearing 64 terminal hydroxyl groups, as macroinitiator. ${ }^{81}$ The end-capping hydroxyl group of this copolymer was then reacted with methoxyPEG-COOH (MPEG-COOH) and $\quad \alpha$-folate $\quad(F A), \omega$-carboxyl $\quad$ PEG (FA-PEG-COOH), in the presence of $N, N$ 'dicyclohexylcarbodiimide (DCC) and 4-(dimetylamino)pyridine (DMAP) as a water scavenger and catalyst, respectively, to afford the corresponding H40-P(MLABe-co-CL)- $b$-MPEG and H40-P(MLABe-co-CL)- $b$-PEG-FA 
amphiphilic copolymers, respectively. Conjugating active-tumor targeting ligands (i.e. FA) to the distal ends of the PEG segments, and doxorubicin as an anticancer drug onto the PMLA units, this latter copolymer ultimately enabled the preparation of unique multifunctional unimolecular micelle drug nanocarriers exhibiting $\mathrm{pH}$-triggered drug release profiles, for targeted cancer therapy.

Finally, graft copolymers P(MLA-g-CL) were developed by Dubois and co-workers from either the "grafting through" (macromonomer technique) or the "grafting from" synthesis of the $\mathrm{P}(\mathrm{MLABe}-\mathrm{g}-\mathrm{CL})$ precursors. The former approach consisted in the anionic simultaneous ROP of MLABe and of the polymerizable $\omega$-end-capping MLABe unit of a PCL (previously obtained upon esterification of PCL-OH and MLA in presence of DCC/DMAP), mediated by KHDD/18-C-6. ${ }^{106}$ The higher MLA-PCL macromonomer content compared to that of the feed, pointed out the faster reaction of MLA-PCL than of MLABe. The second - two-step longer route required the simultaneous anionic copolymerization of MLABe and $(R, S)$-allyl $\beta$ malolactonate (rac-MLAAll) using KHDD/18-C-6. Modification of the pendant allylic functions into hydroxy groups by reaction with mercaptoethanol in the presence of AIBN and without alteration of the molecular parameter of the copolymer, thus generated a multi-hydroxy initiation site polymer backbone eventually enabling the ROP of CL initiated by $\mathrm{AlEt}_{3}$ into PCL side chains. The success of the grafting, and the controlled graft copolyester composition and

molar mass, were supported by ${ }^{1} \mathrm{H}$ NMR data and SEC analyses. Subsequent deprotection of the benzyl groups from these graft copolymers afforded amphiphilic congeners as hinted by preliminary interfacial tension measurements.

\subsection{Copolymerization of MLABe with lactides}

Following the copolymers of PMLABe with other than benzyl alkyl $\beta$-malolactonates which remain the most numerous, the copolymers with lactides segment(s) 
are the second most largely investigated ones. Although both random and block copolymers derived from MLABe and racemic(D,L)-lactide (LA) or (L,L)-lactide (LLA) have been reported, the former are much more common (Table 10).

Table 10. Copolymers of MLABe and lactides: operating conditions and copolymers molecular characteristics

\begin{tabular}{|c|c|c|c|c|}
\hline Copolymer & $\begin{array}{c}\text { Initiator/catalyst } \\
\text { (Solvent, reaction } \\
\text { temperature, reaction time) }\end{array}$ & $\begin{array}{l}\text { M } M_{\mathrm{w}} \text { or } M_{\mathrm{n}} \\
\text { (SEC solvent, } \\
\text { temperature, } \\
\text { standards) }\end{array}$ & $\boldsymbol{Ð}_{\mathbf{M}}$ & Ref. \\
\hline $\mathrm{P}(\mathrm{MLABe}-b-\mathrm{LA})$ & $\begin{array}{c}\mathrm{AlEt}_{3}, \mathrm{HO}-\mathrm{PMLABe}-\mathrm{CO}_{2} \mathrm{Me} \\
\left(\text { Toluene, } 70^{\circ} \mathrm{C}, 30-400 \mathrm{~h} \text { ) }\right.\end{array}$ & $\begin{array}{c}M_{\mathrm{n}, \mathrm{NMR}} 1900-9000 \\
\left(\mathrm{THF}, 35^{\circ} \mathrm{C}, \mathrm{PS}\right)\end{array}$ & $\begin{array}{c}1.43- \\
\text { bimodal }\end{array}$ & 104 \\
\hline $\begin{array}{c}\text { P(MLABe- } b \text {-diHLA) } \\
\text { P(MLABe- } b \text {-mHLA) } \\
\text { P(MLABe- } b \text {-LA }) \\
\end{array}$ & $\begin{array}{l}\mathrm{Sn}(\mathrm{Oct})_{2} / \mathrm{PMLABe}-\mathrm{OH} \\
\quad\left(\text { bulk, } 110^{\circ} \mathrm{C}, 5 \mathrm{~h}\right)\end{array}$ & $\begin{array}{l}M_{\mathrm{n}} 2400-2850 \\
\quad(\mathrm{THF},-,-)\end{array}$ & $1.35-1.37$ & 156 \\
\hline $\begin{array}{l}\mathrm{PLLA}-b-\mathrm{P}\left(\mathrm{Me}_{2} \mathrm{MLABe}-\right. \\
c o-\mathrm{BL})-b-\mathrm{PLLA}\end{array}$ & $\begin{array}{l}\text { 1,3,4-triphenyl-4,5-dihydro- } 1 \mathrm{H} \text { - } \\
\text { 1,2,4-triazol-5-ylidene carbene / } \\
\text { ethylene glycol } \\
\text { (toluene, } 90{ }^{\circ} \mathrm{C}, 16 \mathrm{~d} \text { ) }\end{array}$ & $\begin{array}{c}M_{\mathrm{n}, \mathrm{NMR}} 7100 \\
\left(\mathrm{THF}, 35^{\circ} \mathrm{C}, \mathrm{PS}\right)\end{array}$ & 1.38 & 138 \\
\hline P(MLABe-co-LLA) & $\begin{array}{c}\mathrm{Sn}(\mathrm{Oct})_{2} \\
\text { (bulk, } 110 \text { or } 130{ }^{\circ} \mathrm{C}, 108 \text { or } 48 \\
\text { h, respectively) }\end{array}$ & $\begin{array}{c}M_{\mathrm{n}} 9200-80000 \\
\left(\mathrm{CHCl}_{3}, 35^{\circ} \mathrm{C}, \mathrm{PS}\right)\end{array}$ & $1.8-2.3$ & 157,158 \\
\hline $\mathrm{P}(\mathrm{MLABe}-c o-\mathrm{LA})$ & $\begin{array}{c}\operatorname{Sn}(\mathrm{Oct})_{2} \\
\left.\text { (bulk, } 130^{\circ} \mathrm{C}, 48 \mathrm{~h}\right)\end{array}$ & $\begin{array}{c}M_{\mathrm{n}} 12900- \\
127000 \\
\left(\mathrm{THF}, 25^{\circ} \mathrm{C}, \mathrm{PS}\right)\end{array}$ & $1.63-1.73$ & 159 \\
\hline $\begin{array}{c}\text { GRGDS-P(MLABe-co- } \\
\text { LA) }\end{array}$ & $\begin{array}{c}\mathrm{Sn}(\mathrm{Oct})_{2} \\
\left.\text { (bulk, } 130^{\circ} \mathrm{C}, 48 \mathrm{~h}\right)\end{array}$ & $\begin{array}{l}M_{\mathrm{n}} 17500 \\
(\mathrm{THF},-,-) \\
\end{array}$ & 1.7 & 160 \\
\hline $\begin{array}{c}\text { P(MLABe-co-LA)- } b- \\
\text { MePEG }\end{array}$ & $\begin{array}{l}\mathrm{Sn}(\mathrm{Oct})_{2} / \mathrm{Me}-\mathrm{PEG}-\mathrm{OH} \\
\left.\text { (bulk, } 120-150^{\circ} \mathrm{C}, 48 \mathrm{~h}\right)\end{array}$ & $\begin{array}{c}M_{\mathrm{n}} 3800-8500 \\
\left(\mathrm{THF}, 35^{\circ} \mathrm{C}, \mathrm{PS}\right) \\
\end{array}$ & $1.53-1.96$ & 161 \\
\hline $\begin{array}{c}\mathrm{P} \text { (benzyloxyethylMLAB } \\
\text { e-co-LA) }\end{array}$ & $\begin{array}{c}\operatorname{Sn}(\mathrm{Oct})_{2} \\
\left.\text { (bulk, } 130^{\circ} \mathrm{C}, 48 \mathrm{~h}\right)\end{array}$ & $\begin{array}{c}M_{\mathrm{n}} 9200-108400 \\
\left(\mathrm{THF}, 35^{\circ} \mathrm{C}, \mathrm{PS}\right)\end{array}$ & $1.42-1.72$ & 90,162 \\
\hline
\end{tabular}

-: not reported

Similarly to the above mentioned synthesis of P(MLABe- $b$-CL), the analogous diblock copolymer $\mathrm{P}\left(\mathrm{MLABe}-b\right.$-LA) has been reported. ${ }^{104}$ The three-step approach successively involved the anionic ROP of MLABe mediated by KHDD/18-C-6, the methylation of the resulting $\alpha$-hydroxy, $\omega$-carboxylic acid PMLABe by reaction with trimethylsilyldiazomethane, and finally the coordination-insertion ROP of LA promoted by $\mathrm{AlEt}_{3}$ from this latter macroinitiator. As expected, the ROP of LA was much slower than that of CL, under similar 
operating conditions and the prolonged reaction times (over 2 weeks) required to reach high LA conversion (90\%) induced undesirable transesterification side reactions (bimodal SEC trace). The micelles prepared after hydrogenolysis into the corresponding P(MLA- $b$-LA) copolymer were characterized by their CMC, efficiency of adsorption and monomer coefficient diffusion, thereby revealing themselves as promising candidates for biomedical applications such as drug carriers.

Fully biodegradable polymeric micelles based on functionalized PLA block copolymers were also reported by Möller and co-workers. ${ }^{156}$ PMLA (arising from hydrogenolysis of PMLABe) as the water soluble segment, and poly(dihexyl-substituted lactide) (PdiHLA), poly(monohexyl-substituted lactide) (PmHLA) or PLA as the water insoluble block, were used to prepare the amphiphilic copolymers. The previously formed protected PMLABe-OH was used as a macroinitiator in the ROP of the hydrophobic functionalized diHLA, mHLA, or LA monomers catalyzed by $\mathrm{Sn}(\mathrm{Oct})_{2}$. High yields (80-100\%) of diblock copolymers were thus obtained. The good control of the ROP led to the expected ratios of hydrophilic/hydrophobic units, with the composition of the final copolymers in good agreement with the targeted one. Next, the micellization of the corresponding amphiphilic PMLA analogues into nano-objects of size below $100 \mathrm{~nm}$, their good stability at room temperature, and the complete degradability with different rates at different $\mathrm{pH}$ values as they occur in a possible medical cancer treatment, were demonstrated in comparison to the alike counterparts with monomethoxy PEG hydrophilic blocks, P(MeEG- $b$-LA).

As described above with BL as comonomer, the ROP of L,L-lactide (LLA) promoted by the $\alpha, \omega$-dihydroxy $\mathrm{P}\left(\mathrm{Me}_{2} \mathrm{MLABe}-\mathrm{co}-\mathrm{BL}\right)$ macroinitiator, previously obtained from the metal-free $N$-heterocyclic carbene catalyzed ROP of the dimethyl MLABe $\left(\mathrm{Me}_{2} \mathrm{MLABe}\right)$ and $\mathrm{BL}$, afforded the triblock copolymers PLLA- $b$-P(Me $\left.\mathrm{MLABe}_{2}-c-\mathrm{BL}\right)-b$-PLLA. ${ }^{138}$ 
Random copolymers of $r a c$-MLABe with (L,L)-lactide (LLA) have been more scarcely prepared, as further reported by Wang and co-workers. ${ }^{157,158}$ The ROP of LLA and rac-MLABe was carried out in the presence of $\mathrm{Sn}(\mathrm{Oct})_{2}$ with high yields $(82-94 \%) .{ }^{1} \mathrm{H}$ NMR showed that the composition of the P(MLABe-co-LLA) with a high MLABe content matched well the comonomer feed ratio. The molar mass and the tensile strength of the hydrophobic P(MLABeco-LLA) copolymers decreased with larger MLABe segments. Increasing the MLABe content (8 to $41 \mathrm{~mol} \%$ ) was also found to induce a morphology change of P(MLABe-co-LLA) from crystalline to amorphous with a decrease of the $T_{\mathrm{g}}$ values $\left(59\right.$ to $\left.45^{\circ} \mathrm{C}\right)$, as assessed by DSC. Benzyl deprotection of the copolymers induced a raise of the $T_{\mathrm{g}}$ values as the result of intermolecular hydrogen bonds formation between the pendant carboxylic acid groups thus generated. Again, the $T_{\mathrm{g}}$ values of P(MLA-co-LLA) increased with longer hydrophilic MLA segments. Such relationships between the $T_{\mathrm{g}}$ or $M_{\mathrm{n}}$ values and the MLABe/MLA content were further observed in the similarly synthesized $\mathrm{P}(\mathrm{MLABe}-\mathrm{co}$-LA) and $\mathrm{P}(\mathrm{MLA}-\mathrm{co}-\mathrm{LA})$ using raclactide. ${ }^{159}$ High molar mass $\left(M_{\mathrm{n}}\right.$ up to 80000 g. $\left.\mathrm{mol}^{-1}\right) \mathrm{P}(\mathrm{MLABe}-\mathrm{co}$-LLA) were prepared as precursors to $\mathrm{P}\left(\mathrm{MLA}\right.$-co-LLA) copolymers to be used as scaffolds ${ }^{157}$. The hydrophilicity of the deprotected P(MLA-co-LLA) copolymers increased with greater MLA content. The cellattached efficiency of $3 \mathrm{~T} 3$ mice fibroblasts onto P(MLA-co-LLA) was higher than that of PLLA, and the cells were shown to grow both on the surface and inside the P(MLA-co-LLA)based scaffolds.

$\mathrm{P}(\mathrm{MLABe}-\mathrm{co}$-LA) and $\mathrm{P}(\mathrm{MLA}-\mathrm{co}$-LA) were synthesized in the same route by ChanPark and co-workers ${ }^{159}$ and similarly characterized by ${ }^{1} \mathrm{H}$, FTIR, and SEC analyses with again the same observations. These P(MLA-co-LA) exhibited higher tensile yield stress and modulus than the $\mathrm{P}(\mathrm{MLABe}-\mathrm{co}$-LA) precursors, yet similar to those of PLA. Grafting of P(MLA-co-LA) with bioactive RGD peptide afforded bioconjugates, featuring a better biocompatibility than PLA, as potential candidates for tissue engineering scaffolds. 
In their design of RGD-modified P(MLA-co-LA), Z. Yuan and H. Tang and coworkers also followed the same synthesis. ${ }^{160}$ The composition, molar mass values and hydrophilicity of the GRGDS peptide-containing copolymer were compared to those of the parent homopolymers, namely PLA and PMLA, as evaluated by ${ }^{1} \mathrm{H}$ NMR, SEC, XPS and water contact angle measurements. The molar mass of the GRGDS-P(MLA-co-LA) was found lower than that of PMLA. Blood compatibility tests suggested that the random copolymer GRGDSconjugate could be a potentially useful material in vascular tissue engineering.

Finally, with the aim to functionalize the PLA block of PLA- $b$-PEG, Yuan and coworkers developed copolymers with PMLABe, PLA and PEG segments. ${ }^{161}$ The simultaneous bulk ring-opening copolymerization of D,L-lactide (LA) and rac-MLABe was catalyzed by $\mathrm{Sn}(\mathrm{Oct})_{2}$ in presence of Me-PEG-OH as the initiator, thereby affording Me-PEG- $b-\mathrm{P}(\mathrm{LA}-\mathrm{co}-$ MLABe). The influence of various parameters (reaction temperature, reaction time, monomer and initial initiator loading) was studied. Along with ${ }^{1} \mathrm{H}$ and ${ }^{13} \mathrm{C}$ NMR, FTIR and SEC analyses, this study revealed that the molar mass of the copolymer decreased with larger MLABe feeds. The resulting PMLA analogous amphiphilic copolymer formed nanospheres whose morphology and degradation behavior were then investigated.

The P(MLA-g-LA) grafted copolymers have been prepared without going through the PMLABe deprotection approach. ${ }^{84}$ A polylactide PLA-OH was first coupled to malolactonic acid in presence of DCC to afford the MLA-end-capped PLA (MLA-PLA), which was subsequently ring-opened polymerized via the anionic route (TEABz) to give the desired P(MLA-g-PLA) copolymer. Such biodegradable graft copolymers were planned for bioactive molecules encapsulation and bioarticicial membranes. Also, note that the $\mathrm{Sn}(\mathrm{Oct})_{2}$ mediated simultaneous ROP of rac-benzyloxyethyl $\beta$-malolactonate and LA similarly afforded the corresponding random copolymers that were subsequently deprotected into the corresponding amphiphilic hydroxyetlyl $\beta$-malolactonate block copolymers of LA, as reported by Yuan and 
co-workers. ${ }^{90,162}$ The composition and structure of the copolymers were determined by ${ }^{1} \mathrm{H}$ and ${ }^{13} \mathrm{C}$ NMR analyses which displayed signals assigned to monomer sequence distributions supporting the random structure. DSC analysis revealed a unique $T_{\mathrm{g}}$ which decreased with larger MLABe segments. The absence of crystallization temperature suggested the formation of amorphous copolymers from the two racemic monomers. The degradation was faster for copolymers with larger hydroxyetlyl $\beta$-malolactonate content. Cell attachment efficiency was demonstrated with human umbilical vein endothelial cells.

\subsection{Copolymerization of MLABe with other monomers}

Besides lactones and lactides, the only other monomers which have been copolymerized with MLABe are, to our knowledge, poly(ethylene glycol) (PEG) and poly(trimethylene carbonate) (PTMC) (Table 11).

Table 11. Copolymers of MLABe and other monomers: operating conditions and copolymers molecular characteristics

\begin{tabular}{|c|c|c|c|c|}
\hline Copolymer & $\begin{array}{c}\text { Initiator/catalyst } \\
\text { (Solvent, reaction temperature, } \\
\text { reaction time) }\end{array}$ & $\begin{array}{l}M_{\mathrm{w}} \text { or } M_{\mathrm{n}} \\
\text { (SEC solvent, } \\
\text { temperature, } \\
\text { standards) }\end{array}$ & $\boldsymbol{Ð}_{\mathbf{M}}$ & Ref. \\
\hline PMLABe- $b$-PEG & $\begin{array}{c}t \text {-BuP } / \text { /MeO-PEG-COOH } \\
(\mathrm{THF}, \mathrm{RT}, 72 \mathrm{~h})\end{array}$ & $\begin{array}{c}M_{\mathrm{n}} 450000 \\
\left(\mathrm{THF} / \mathrm{NEt}_{3}, 35^{\circ} \mathrm{C}, \mathrm{PS}\right)\end{array}$ & 1.55 & 163 \\
\hline $\begin{array}{l}\text { PMLABe- } b \text {-PEG } \\
\text { PMLABe- } b- \\
\text { PEG-Biotin }\end{array}$ & $\begin{array}{c}\text { Knaphtalide/18-C-6 } \\
\text { MeO-PEG-COOH }\left(M_{\mathrm{n}, \mathrm{NMR}} 1850\right) \\
\text { Biotin-PEG-COOH } \\
\left(M_{\mathrm{n}, \mathrm{NMR}} 2730\right)\end{array}$ & $\begin{array}{l}M_{\mathrm{n}, \mathrm{NMR}} 14000-15500 \\
\quad \text { for PMLABe } \\
\left(\mathrm{THF} / \mathrm{NEt}_{3}, 30^{\circ} \mathrm{C}, \mathrm{PS}\right)\end{array}$ & $1.20-1.30$ & 164,165 \\
\hline $\mathrm{P}(\mathrm{MLABe}-b-\mathrm{TMC})$ & $\begin{array}{c}{\left[\left(\mathrm{BDI}^{\mathrm{iPr}}\right) \mathrm{Zn}\left(\mathrm{N}\left(\mathrm{SiMe}_{3}\right)_{2}\right)\right] / \mathrm{BnOH}} \\
\left(\text { bulk, } 40^{\circ} \mathrm{C}, 16-74 \mathrm{~h}\right)\end{array}$ & $\begin{array}{c}M_{\mathrm{n}} 960-7600 \\
\left(\mathrm{THF}, 25^{\circ} \mathrm{C}, \mathrm{PS}\right)\end{array}$ & $1.29-1.53$ & 82 \\
\hline $\mathrm{P}(\mathrm{MLABe}-c o-\mathrm{TMC})$ & $\begin{array}{c}{\left[\left(\mathrm{BDI}^{\mathrm{iPr}}\right) \mathrm{Zn}\left(\mathrm{N}\left(\mathrm{SiMe}_{3}\right)_{2}\right)\right] / \mathrm{BnOH}} \\
\quad\left(\text { bulk, } 40^{\circ} \mathrm{C}, 16-96 \mathrm{~h}\right)\end{array}$ & $\begin{array}{l}M_{\mathrm{n}} 2400-4300 \\
\left(\mathrm{THF}, 25^{\circ} \mathrm{C}, \mathrm{PS}\right)\end{array}$ & $1.30-1.62$ & 82 \\
\hline
\end{tabular}

Besides the star-shaped miktoarm triblock copolymers s[PCL- $b$-PEG- $b$-PMLABe],${ }^{108}$ the $\mathrm{H} 40-\mathrm{P}(\mathrm{MLABe}-c o-\mathrm{CL})-b-\mathrm{MPEG} / \mathrm{PEG}-\mathrm{FA}^{81}$ and $\mathrm{P}(\mathrm{MLABe}-c o-\mathrm{LA})-b-\mathrm{MePEG}{ }^{161}$ 
mentioned above, only a couple of PMLABe copolymers incorporating PEG segments have been reported. Similarly, copolymers of PMLABe are limited to, besides segments derived from $\beta$-latones, CL or LAs, trimethylene carbonate (TMC).

Using the $\quad t$-BuP 4 (1-tert-butyl-4,4,4-tris(dimethylamino)-2,2bis[tris(dimethylamino)phosphoranyl-idenamino]- $2 \Lambda^{5}, 4 \Lambda^{5}$-catenadi-(phosphazene)) phosphazene base as catalyst in presence of $\alpha$-methoxy, $\omega$-carboxylic acid PEG as the initiator, Coulembier and co-workers prepared PMLABe- $b$-PEG copolymers upon ROP of rac-MLABe. ${ }^{163}$ The initial monomer-to-initiator ratio as high as 9500 afforded a high molar mass copolymer $\left(M_{\mathrm{n}}=450000 \mathrm{~g} \cdot \mathrm{mol}^{-1}\right)$ upon complete monomer conversion as monitored by FTIR. The objective of this single experiment was to evaluate the control of the molar mass of the PMLABe homopolymers prepared by various phosphazene bases.

Recently, Cammas-Marion and co-workers have synthesized PMLABe- $b$-PEG by mediating the ROP of MLABe from $\alpha$-methoxy, $\omega$-carboxy PEG or $\alpha$-biotin, $\omega$-carboxy PEG prepolymers. The polymerization was monitored by FTIR until complete disappearance of the characteristic lactone absorption $\left(v 1850 \mathrm{~cm}^{-1}\right)$ affording the desired copolymers which were characterized by NMR and SEC. Well-defined degradable and biocompatible functional nanoparticles were next prepared and evaluated for their in vitro toxicity on normal and cancer cell lines. Decorated with cyclic RGD peptide, these nanoparticles were found effective for drug delivery to hepatoma cells in vitro. ${ }^{164,165}$

The successful (immortal) ROP of MLABe initiated by the zinc $\beta$-diketiminate complex in presence of $\mathrm{BnOH}^{82}$ then opened the route to its copolymerization with other cyclic monomers typically ring-opened polymerized by this same catalytic system ${ }^{119,}{ }^{120}$ such as TMC. ${ }^{166-168}$ Block copolymers P(MLABe- $b$-TMC) were synthesized by Guillaume and coworkers upon sequential ROP of MLABe and TMC, regardless of the order of monomer addition. However, these were more easily prepared upon polymerization of TMC prior to 
MLABe, the conversion of the $\beta$-lactone being high-to-quantitative, whereas when MLABe was introduced first, the TMC conversion remained very sluggish. Alternatively, the block copolymers were prepared upon coupling of the homopolymers PMLABe-COOH and PTMC-OH pre-synthesized using DCC and DMAP. The simultaneous copolymerization afforded the corresponding $\mathrm{P}(\mathrm{MLABe}-\mathrm{co}$-TMC) random copolymers. These well-defined copolymers have been characterized by NMR, FTIR, SEC and DSC. This was the first report of a metallo-organic catalyzed coordination-insertion ROP of MLABe. Furthermore, these represent to date the only PMLABe-polycarbonate examples.

\subsection{Concluding remarks on the copolymerization of MLABe}

Benefiting from the latest advances in the ring-opening homopolymerization of MLABe, several copolymers of this $\beta$-lactone have been synthesized (Scheme 16). However, these MLABe copolymers remain limited to a few cyclic esters (mainly lactones, diesters, carbonates) that are typically ring-opened polymerized according to the same ROP mechanism. Also, MLABe copolymers are essentially block or random ones with only a few grafted examples being reported. Regarding block copolymers, these have been most commonly synthesized from a two-step sequential approach through a nucleophilic ROP initiated by metallo-organic (aluminum, tin, zinc derivatives) or organic (lipase, amines, acetate, guanidine, amidine, phosphazene) species. More rarely, the synthesis involved the coupling of the two previously isolated homopolymers, or the chain-end chemical modification of a pre-synthesized homopolymer into a macroinitiator to be subsequently used to mediate the ROP of the second monomer. Besides, random copolymers have been synthesized by simultaneous copolymerization promoted by these same initiator/catalyst systems. Generally, the copolymerization of MLABe is quite long requiring several-to-many days. The most active systems unveiled operate within 1-3 days. Also, latest results have evidenced that 
microstructural control in the copolymerization of MLABe and cyclic esters can be achieved via catalytic tuning. Remarkably, block copolymers $\mathrm{P}(\mathrm{MLABe}-b-\mathrm{BL})$ have been prepared upon the simultaneous copolymerization of MLABe and BL mediated by BEMP.

\section{Scheme 16. Copolymers of MLABe with other cyclic esters/carbonates}
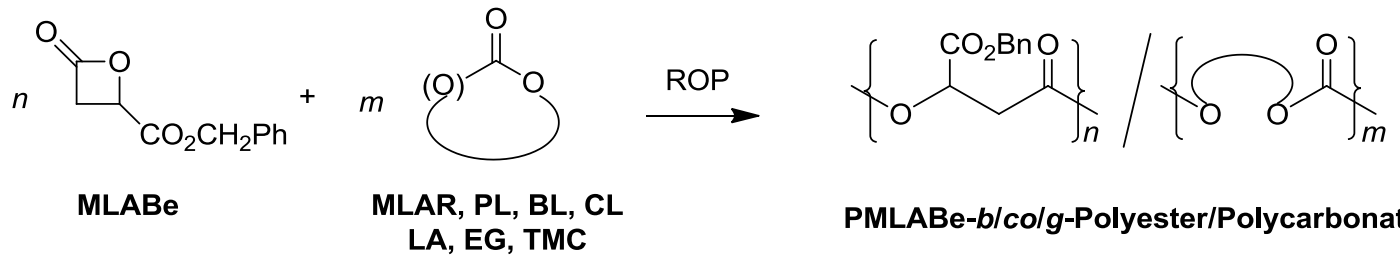

PMLABe-b/colg-Polyester/Polycarbonate

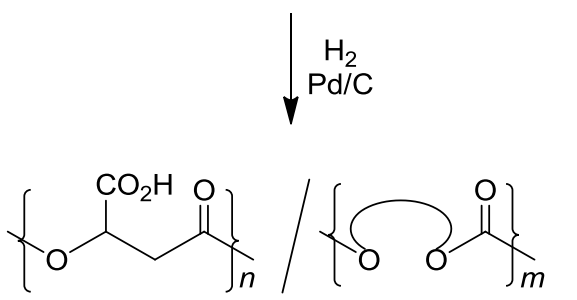

PMLA-b/colg-Polyester/Polycarbonate

\section{Conclusion and perspectives}

The synthesis and ring-opening (co)polymerization of MLABe nowadays afford a controlled route to $\operatorname{PMLA}(\mathrm{Be})$ and $\operatorname{PMLA}(\mathrm{Be}) /$ polyester or $\mathrm{PMLA}(\mathrm{Be}) /$ polycarbonate copolymers. MLABe, as a $\beta$-lactone, is a reluctant monomer towards ROP. Also, in regard to the ubiquitous BL related monomer, the ROP of MLABe has been less studied. Initiating systems ranging from ionic ones to metallic derivatives or organic nucleophiles have been investigated, but their diversity remains quite limited in direct correlation with the restricted number of studies. Also, the efficiency of these initiator/catalyst systems is restricted in terms of activity (poor rate of homopolymerization and of copolymerization as compared to that of other larger cyclic lactones), as well as productivity (the issue in this regard being essentially the purity of the monomer). However, recent advances with metal-free organic systems featuring shorter (co)polymerization times are very promising. Significant improvements have also been achieved in terms of polymerization control. Well-defined (co)polymers with identified end- 
capping groups can nowadays be easily obtained from a suitably chosen initiator/catalyst system, under mild operating conditions $\left(40-60{ }^{\circ} \mathrm{C}\right.$ in solution or bulk). The living characteristics of the ROP have also been demonstrated from a few initiators/catalysts opening up the route to macromolecular engineering. Several PMLABe topologies have been obtained with polyester/polycarbonate segments thus enabling to tune and further broaden the properties of these polymers, and of their scope as well. While some achievements in tailoring the macromolecular architecture and in modulating the copolymer microstructure have been made upon judicious catalyst tuning, these are only the first signs of further success. Hinted by the progress on the stereocontrolled ROP of BL, advances in the stereocontrolled ROP of MLABe can be anticipated from stereoselective catalyst systems, most likely (yet not exclusively) from well-defined metallic complexes. Preliminary promising results have been recently obtained toward the synthesis of syndiotactic PMLARs $\left(\mathrm{R}=\mathrm{Be}\right.$ and All). ${ }^{169}$ Finally, whereas discrete metallic as well as nonmetallic systems have shown good overall performances, there is still room for further improvements. In particular, since they restrain toxicity issues, the latter organic systems should give rise to a growing interest, especially toward the highly desirable metal-free synthesis of polyesters intended for biomedical applications.

PMLABe (co)polymers can be hydrogenolyzed under mild operating conditions to provide the PMLA analogues, thus offering either hydrophobic or hydrophilic biocompatible and biodegradable polyesters. The recent advances on PMLABe chemistry reported in this review will certainly enhance the attention paid to such copolymers and to their potential biomedical outcomes. Several authors have addressed some of the applications of PMLA, reporting on its physiological role, its intrinsic toxicity or immunological effects, or on the structure-properties relationships in the design of nanoconjugates for controlled drug delivery, and of biomaterials for bone repair. ${ }^{13-19,81,84,86,87,98,100,170-175}$ Recent work by Cammas-Marion and co-workers. ${ }^{164,165}$ Ding and co-workers ${ }^{176}$ or Penichet and Ljubimova and co-workers ${ }^{177}$ 
on the use of PMLA derivatives for site-specific anti-cancer drug delivery, endosomolytic drug delivery or simultaneous immunostimulation and inhibition of tumor growth, are nice illustrations exemplifying the possible outcomes.

\section{Acknowledgments}

Thanks are due to the CNRS, the University of Rennes 1, the Institut des Sciences Chimiques de Rennes, and the Region Bretagne for financial support to our contribution in this field. Gratitude is expressed to the research fellows whose names appear in the reference list. 


\section{References}

1. B. Laycock, P. Halley, S. Pratt, A. Werker and P. Lant, Prog. Polym. Sci., 2013, 38, 536-583.

2. C. Zhu, S. Chiu, J. P. Nakas and C. T. Nomura, J. Appl. Polym. Sci., 2013, 130, 1-13.

3. S. Taguchi, T. Iwata, H. Abe and Y. Doi, Polym. Sci. A Compr. Ref., 2012, 157-182.

4. D. B. Hazer, E. Kılıçay and B. Hazer, Mater. Sci. Eng.: C, 2012, 32, 637-647.

5. J. Lu, R. C. Tappel and C. T. Nomura, J. Macromol. Sci. C: Polym. Rev., 2009, 49, 226248.

6. $\quad$ G.-Q. Chen, Chem. Soc. Rev., 2009, 38, 2434-2446.

7. R. W. Lenz and R. H. Marchessault, Biomacromolecules, 2005, 6, 1-8.

8. M. Zinn, B. Witholt and T. Egli, Adv. Drug. Deliv. Rev., 2001, 53, 5-21.

9. K. Sudesh, H. Abe and Y. Doi, Prog. Polym. Sci., 2000, 25, 1503-1555.

10. Y. Doi, Microbial Polyesters, VCH Publishers, New York, 1990.

11. M. Vert and R. W. Lenz, ACS Polym. Prepr., 1979, 1, 608-611.

12. R. J. Pounder and A. P. Dove, Polym. Chem., 2010, 1, 260-271.

13. J. Y. Ljubimova, M. Fujita, A. V. Ljubimov, V. P. Torchilin, K. L. Black and E. Holler, Nanomedicine, 2008, 3, 247-265.

14. I. Taniguchi, W. A. Kuhlman, A. M. Mayes and L. G. Griffith, Polym. Int., 2006, 55, 1385-1397.

15. O. Coulembier, P. Degée, J. L. Hedrick and P. Dubois, Prog. Polym. Sci., 2006, 31, $723-$ 747.

16. M. Vert, Polym. Degrad. Stab., 1998, 59, 169-175, and references therein.

17. M. Vert, Makromol. Chem., Macromol. Symp., 1986, 6, 109-122.

18. S. Inoue, H. Ding, J. Portilla-Arias, J. Hu, B. Konda, M. Fujita, A. Espinoza, S. Suhane, M. Riley, M. Gates, R. Patil, M. L. Penichet, A. V. Ljubimov, K. L. Black, E. Holler and J. Y. Ljubimova, Cancer Res., 2011, 71, 1454-1464.

19. C. Braud, C. Bunel and M. Vert, Polym. Bull., 1985, 13, 293-299.

20. M. Vert, in Polymers in Controlled Drug Delivery, eds. L. Illum and S. S. Davis, Bristol, , 1987, pp. 117-130

21. K. Shimada and K. Matsushima, Agric. Biol. Chem., 1969, 33, 544-548.

22. K. Shimada and K. Matsushima, Agric. Biol. Chem., 1969, 33, 549-553.

23. K. Shimada, K. Matsushima, J. Fukumoto and T. Yamamoto, Biochem. Biophys. Res. Commun., 1969, 35, 619-624.

24. S. Cammas, P. Guerin, J. P. Girault, E. Holler, Y. Gache and M. Vert, Macromolecules, 1993, 26, 4681-4684.

25. D. Chaturvedi, S. Mishra, P. Tandon, J. A. Portilla-Arias and S. Muñoz-Guerra, Polymer, 2012, 53, 2681-2690.

26. X. Zou, Y. Zhou and S.-T. Yang, Biotechnol. Bioeng., 2013, 110, 2105-2113.

27. C. Korherr, M. Roth and E. Holler, Can. J. Microbiol., 1995, 41, 192-199.

28. T. Leathers and P. Manitchotpisit, Biotechnol. Lett., 2013, 35, 83-89.

29. H. Zhang, J. Cai, J. Dong, D. Zhang, L. Huang, Z. Xu and P. Cen, Appl. Microbiol. Biotechnol., 2011, 92, 295-303.

30. Christoph M. Krell and D. Seebach, Eur. J. Org. Chem., 2000, 2000, 1207-1218.

31. K. Rathberger, H. Reisner, B. Willibald, H.-P. Molitoris and E. Holler, Mycol. Res., 1999, 103, 513-520.

32. S.-J. Liu and A. Steinbüchel, Biotechnol. Lett., 1997, 19, 11-14.

33. S. Liu and A. Steinbüchel, Appl. Microbiol. Biotechnol., 1996, 46, 273-278.

34. T. Nakajima-Kambe, N. Hirotani and T. Nakahara, J. Ferment. Bioeng., 1996, 82, 411413. 
35. B. Angerer and E. Holler, Biochemistry, 1995, 34, 14741-14751.

36. N. Nagata, T. Nakahara, T. Tabuchi, R. Morita, J. R. Brewer and S. Fujishige, Polym. J., 1993, 25, 585-592.

37. N. Nagata, T. Nakahara and T. Tabuchi, Biosci., Biotechnol., Biochem., 1993, 57, 638642.

38. E. Holler, B. Angerer, G. Achhammer, S. Miller and C. Windisch, FEMS Microbiol. Rev., 1992, 103, 109-118.

39. E. Holler, G. Achhammer, B. Angerer, B. Gantz, C. Hambach, H. Reisner, B. Seidel, C. Weber, C. Windisch, C. Braud, P. Guerin and M. Vert, Eur. J. Biochem., 1992, 206, 16.

40. H. Fischer, S. Erdmann and E. Holler, Biochemistry, 1989, 28, 5219-5226.

41. Y. Peleg, B. Stieglitz and I. Goldberg, Appl. Microbiol. Biotechnol., 1988, 28, 69-75.

42. K. Matsushima and K. Shimada, Agric. Biol. Chem., 1970, 34, 47-52.

43. K. Matsushima, Agric. Biol. Chem., 1970, 34, 1741-1744.

44. B.-S. Lee and E. Holler, FEMS Microbiol. Lett., 2000, 193, 69-74.

45. T. Kajiyama, H. Kobayashi, T. Taguchi, K. Kataoka and J. Tanaka, Biomacromolecules, 2004, 5, 169-174.

46. T. Kajiyama, T. Taguchi, H. Kobayashi, K. Kataoka and J. Tanaka, Polym. Degrad. Stab., 2003, 81, 525-530.

47. T. Kajiyama, T. Taguchi, H. Kobayashi, K. Kataoka and J. Tanaka, Polym. Bull., 2003, 50, 69-75.

48. Y. Abe, S. Matsumura and K. Imai, J. Jpn. Oil Chemist Soc., 1986, 35, 937-944.

49. R. Nakashima, T. Okuda, M. Okazaki and T. Ouchi, Rep. Fac. Eng. Tottori Univ., 1977, 8, 124-127.

50. $\quad$ D. L. Wise, United States Pat., 3, 978, 203, 1976.

51. N. Belcheva, T. Zlatkov, I. M. Panayotov and C. Tsvetanov, Polymer, 1993, 34, 22132217.

52. H. Uyama and S. Kobayashi, Adv. Polym. Sci., 2006, 194, 51-67.

53. S. Matsumura, Adv. Polym. Sci., 2006, 194, 95-132.

54. S. Matsumura, H. Beppu and K. Toshima, Chem. Lett., 1999, 28, 249-250.

55. S. Matsumura, H. Beppu and K. Toshima, ACS Symp. Ser., 1998, 684, 74-89.

56. S. Matsumura, H. Beppu, K. Nakamura, S. Osanai and K. Toshima, Chem. Lett., 1996, 26, 795-796.

57. S. Matsumura, H. Beppu and K. Toshima, Polym. Mater. Sci. Eng., 1996, 74, 2-3.

58. O. Coulembier and P. Dubois, in Handbook of Ring-Opening Polymerization, eds. P. Dubois, O. Coulembier and J.-M. Raquez, Weinheim: Wiley, 2009, pp. 227-254

59. J.-F. Carpentier, Macromol. Rapid Commun., 2010, 31, 1696-1705.

60. C. M. Thomas, Chem. Soc. Rev., 2010, 39, 165-173.

61. C. Mabille, M. Masure, P. Hémery and P. Guérin, Polym. Bull., 1998, 40, 381-387.

62. S. Cammas, I. Renard, V. Langlois and P. Guérin, Polymer, 1996, 37, 4215-4220.

63. R. Reichardt and B. Rieger, Adv. Polym. Sci., 2012, 245, 49-90.

64. T. L. Church, Y. D. Y. L. Getzler, C. M. Byrne and G. W. Coates, Chem. Commun., 2007, 657-674.

65. M. Allmendinger, R. Eberhardt, L. G. A., M. Ferenc and B. Rieger, ACS Symp. Ser., 2003, 857, 114-130.

66. M. Larchevêque and Y. Petit, Bull. Soc. Chim. Fr., 1989, 1, 130-139.

67. M. Larchevêque and Y. Petit, Tetrahedron Lett., 1987, 28, 1993-1996.

68. A. Aden, J. Bozell, J. Holladay, J. White and A. Manheim, in Top Value Added Chemicals From Biomass, Volume 1: Results of Screening for Potential Candidates from Sugars and Synthesis Gas, eds. T. Werpy and G. Petersen, Washington DC, 2004, 
69. J. J. Bozell and G. R. Petersen, Green Chem., 2010, 12, 539-554.

70. R. Lenz and M. Vert, United States Pat., 4,265,247, 1981.

71. P. Guerin, J. Francillette, C. Braud and M. Vert, Makromol. Chem., Macromol. Symp., 1986, 6, 305-314.

72. D. B. Johns, R. W. Lenz and M. Vert, J. of Bioact. and Compat. Polym., 1986, 1, 4760.

73. R. W. Lenz and P. Guerin, Polymer Science and Technology (Plenum), 1983, 23, 219230.

74. G. O. Rankin, H. Sun, B. McCain, J. L. Hubbard and M. Chai, Synthesis, 2002, 2002, 2165-2167.

75. S. Varugese, S. Thomas, S. Haleema, T. Puthiaparambil and I. Ibnusaud, Tetrahedron Lett., 2007, 48, 8209-8212.

76. S. C. Arnold and R. W. Lenz, Makromol. Chem., Macromol. Symp., 1986, 6, 285-303.

77. S. Cammas, I. Renard, K. Boutault and P. Guérin, Tetrahedron: Asymmetry, 1993, 4, 1925-1930.

78. P. Ramiandrasoa, P. Guérin, J. Girault, P. Bascou, A. Hammouda, S. Cammas and M. Vert, Polym. Bull., 1993, 30, 501-508.

79. C. Barbaud, S. Cammas-Marion and P. Guérin, Polym. Bull., 1999, 43, 297-304.

80. O. Coulembier, P. Degée, S. Cammas-Marion, P. Guérin and P. Dubois, Macromolecules, 2002, 35, 9896-9903.

81. X. Yang, J. J. Grailer, S. Pilla, D. A. Steeber and S. Gong, Bioconjugate Chem., 2010, 21, 496-504.

82. M. Helou, G. Moriceau, Z. W. Huang, S. Cammas-Marion and S. M. Guillaume, Polym. Chem., 2011, 2, 840-850.

83. C. G. Jaffredo, J.-F. Carpentier and S. M. Guillaume, Polym. Chem., 2013, 4, 38373850 .

84. S. Cammas-Marion and P. Guérin, Macromol. Symp., 2000, 153, 167-186.

85. S. Cammas-Marion, M.-M. Béar, A. Harada, P. Guérin and K. Kataoka, Macromol. Chem. Phys., 2000, 201, 355-364.

86. S. Osanai and K. Nakamura, Biomaterials, 2000, 21, 867-876.

87. V. Jeanbat-Mimaud, C. Barbaud, J.-P. Caruelle, D. Barritault, S. Cammas-Marion, V. Langlois and P. Guérin, C. R. Acad Sci. - Series IIC - Chem., 1999, 2, 393-401.

88. M.-A. Leboucher-Durand, V. Langlois and P. Guérin, React. Funct. Polym., 1996, 31, 57-65.

89. R. Bizzarri, F. Chiellini, R. Solaro, E. Chiellini, S. Cammas-Marion and P. Guerin, Macromolecules, 2002, 35, 1215-1223.

90. L. Wang, X. Jia and Z. Yuan, Polymer, 2006, 47, 6978-6985.

91. L. Moine, S. Cammas, C. Amiel, P. Guerin and B. Sebille, Polymer, 1997, 38, 31213127.

92. Y. Etienne and R. Soulas, J. Polym.Sci., Part C, 1966, 4, 1061-1074.

93. K. Teranishi, M. Iida, T. Araki, S. Yamashita and H. Tani, Macromolecules, 1974, 7, 421-427.

94. A. Hofman, R. Szymański, S. Słomkowski and S. Penczek, Makromol. Chem., 1984, 185, 655-667.

95. H. R. Kricheldorf, J. M. Jonté and R. Dunsing, Makromol. Chem., 1986, 187, 771-785.

96. A. C. Albertsson and R. Palmgren, J. Macromol. Sci., Part A, 1996, 33, 747-758.

97. R. Lenz, D. B. Johns, M. Vert, M. Camps and S. Boileau, ACS Polym. Prepr., 1986, 27, 175-176.

98. P. Guerin, M. Vert, C. Braud and R. Lenz, Polym. Bull., 1985, 14, 187-192. 
99. P. Fournie, D. Domurado, P. Guerin, C. Braud, M. Vert and J.-C. Madelmont, J. of Bioact. and Compat. Polym., 1990, 5, 381-395.

100. R. Bizzarri, F. Chiellini, C. K. Ober, W. M. Saltzman and R. Solaro, Macromol. Chem. Phys., 2002, 203, 1684-1693.

101. M. M. Bear, K. Lozac'h, S. Randriamahefa, V. Langlois, R. Bourbouze and P. Guerin, Polymer, 1999, 40, 6521-6528.

102. C. Monne, D. Robic, G. Campion, R. Bourbouze, A. Rimbault, M. Masure, V. Langlois, P. Hemery and P. Guerin, Chirality, 1996, 8, 300-304.

103. S. Cammas, M.-M. Béar, L. Moine, R. Escalup, G. Ponchel, K. Kataoka and P. Guérin, Int. J. Biol. Macromol., 1999, 25, 273-282.

104. O. Coulembier, J. Ghisdal, P. Degée and P. Dubois, Arkivoc, 2007, 57-70.

105. O. Coulembier, P. Degée and P. Dubois, Macromol. Chem. Phys., 2006, 207, 484-491.

106. O. Coulembier, P. Degée, P. Gerbaux, P. Wantier, C. Barbaud, R. Flammang, P. Guérin and P. Dubois, Macromolecules, 2005, 38, 3141-3150.

107. O. Coulembier, P. Degée, P. Guérin and P. Dubois, Langmuir, 2003, 19, 8661-8666.

108. J. Rieger, O. Coulembier, P. Dubois, K. V. Bernaerts, F. E. Du Prez, R. Jérôme and C. Jérôme, Macromolecules, 2005, 38, 10650-10657.

109. N. Manolova, I. Rashkov, J. Huguet and M. Vert, Mater. Sci. Forum, 1992, 91-93, 805810.

110. A. Buchard, C. Bakewell, J. Weiner and C. Williams, in Organometallics and Renewables, eds. M. A. R. Meier, B. M. Weckhuysen and P. C. A. Bruijnincx, Springer Berlin Heidelberg, 2012, vol. 39, ch. 5, pp. 175-224,Topics in Organometallic Chemistry.

111. H. R. Kricheldorf, N. Scharnagl and Z. Jedlinski, Polymer, 1996, 37, 1405-1411.

112. P. Lecomte and C. Jerome, Adv. Polym. Sci., 2012, 245, 173-218.

113. H. R. Kricheldorf, M. Garaleh and G. Schwarz, J. Macromol. Sci., Part A, 2005, 42, 139-148.

114. C. G. Jaffredo, J.-F. Carpentier and S. M. Guillaume, Macromol. Rapid Commun., 2012, 33, 1938-1944.

115. R. A. Gross, Y. Zhang, G. Konrad and R. W. Lenz, Macromolecules, 1988, 21, $2657-$ 2668.

116. R. A. Gross, G. Konrad, Y. Zhang and R. W. Lenz, ACS Polym. Prepr., 1987, 28, $373-$ 374.

117. O. Coulembier, P. Degée, C. Barbaud, P. Guérin and P. Dubois, Polym. Bull., 2004, 51, 365-372.

118. C. G. Jaffredo, J.-F. Carpentier and S. M. Guillaume, Macromolecules, 2013, 46, 67656776.

119. S. M. Guillaume and J.-F. Carpentier, Catal. Sci. Technol., 2012, 2, 898-906.

120. N. Ajellal, J.-F. Carpentier, C. Guillaume, S. M. Guillaume, M. Helou, V. Poirier, Y. Sarazin and A. Trifonov, Dalton Trans., 2010, 39, 8363-8376.

121. M. Cheng, D. R. Moore, J. J. Reczek, B. M. Chamberlain, E. B. Lobkovsky and G. W. Coates, J. Am. Chem. Soc., 2001, 123, 8738-8749.

122. L. R. Rieth, D. R. Moore, E. B. Lobkovsky and G. W. Coates, J. Am. Chem. Soc., 2002, 124, 15239-15248.

123. C. Guillaume, J.-F. Carpentier and S. M. Guillaume, Polymer, 2009, 50, 5909-5917.

124. M. Helou, O. Miserque, J.-M. Brusson, J.-F. Carpentier and S. M. Guillaume, Chem CatChem, 2010, 2, 306-313.

125. M. Fevre, J. Pinaud, Y. Gnanou, J. Vignolle and D. Taton, Chem. Soc. Rev., 2013, 42, 2142-2172. 
126. M. Fèvre, J. Vignolle, Y. Gnanou and D. Taton, Polym. Sci. A Compr. Ref., 2012, 67115.

127. M. K. Kiesewetter, E. J. Shin, J. L. Hedrick and R. M. Waymouth, Macromolecules, 2010, 43, 2093-2107.

128. A. P. Dove, in Handbook of Ring-Opening Polymerization, eds. O. Coulembier, P. Dubois and J.-M. Raquez, Wiley, Weinheim, 2009, pp. 357-378

129. N. E. Kamber, W. Jeong, R. M. Waymouth, R. C. Pratt, B. G. G. Lohmeijer and J. L. Hedrick, Chem. Rev., 2007, 107, 5813-5840.

130. O. Dechy-Cabaret, B. Martin-Vaca and D. Bourissou, Chem. Rev., 2004, 104, 61476176.

131. L. Simón and J. M. Goodman, J. Org. Chem., 2007, 72, 9656-9662.

132. R. C. Pratt, B. G. G. Lohmeijer, D. A. Long, R. M. Waymouth and J. L. Hedrick, J. Am. Chem. Soc., 2006, 128, 4556-4557.

133. B. G. G. Lohmeijer, R. C. Pratt, F. Leibfarth, J. W. Logan, D. A. Long, A. P. Dove, F. Nederberg, J. Choi, C. Wade, R. M. Waymouth and J. L. Hedrick, Macromolecules, 2006, 39, 8574-8583.

134. O. Coulembier, B. G. G. Lohmeijer, A. P. Dove, R. C. Pratt, L. Mespouille, D. A. Culkin, S. J. Benight, P. Dubois, R. M. Waymouth and J. L. Hedrick, Macromolecules, 2006, 39, 5617-5628.

135. G. W. Nyce, T. Glauser, E. F. Connor, A. Möck, R. M. Waymouth and J. L. Hedrick, J. Am. Chem. Soc., 2003, 125, 3046-3056.

136. E. F. Connor, G. W. Nyce, M. Myers, A. Möck and J. L. Hedrick, J. Am. Chem. Soc., 2002, 124, 914-915.

137. E. Brule, V. Guerineau, P. Vermaut, F. Prima, J. Balogh, L. Maron, A. M. Z. Slawin, S. P. Nolan and C. M. Thomas, Polym. Chem., 2013, 4, 2414-2423.

138. O. Coulembier, L. Mespouille, J. L. Hedrick, R. M. Waymouth and P. Dubois, Macromolecules, 2006, 39, 4001-4008.

139. O. Coulembier, X. Delva, J. L. Hedrick, R. M. Waymouth and P. Dubois, Macromolecules, 2007, 40, 8560-8567.

140. W. Jeong, J. L. Hedrick and R. M. Waymouth, J. Am. Chem. Soc., 2007, 129, 84148415.

141. J. W. Kramer, D. S. Treitler, E. W. Dunn, P. M. Castro, T. Roisnel, C. M. Thomas and G. W. Coates, J. Am. Chem. Soc., 2009, 131, 16042-16044.

142. A. Amgoune, C. M. Thomas, S. Ilinca, T. Roisnel and J.-F. Carpentier, Angew. Chem. Int. Ed., 2006, 45, 2782-2784.

143. R. Bizzarri, F. Chiellini, C. K. Ober, W. M. Saltzman, R. Solaro and E. Chiellini, Macromol. Symp., 2003, 197, 303-314.

144. S. Cammas-Marion and P. Guérin, Des. Monomers Polym., 2000, 3, 77-93.

145. L. Moine, S. Cammas, C. Amiel, E. Renard, B. Sébille and P. Guérin, Macromol. Symp., 1998, 130, 45-52.

146. A. Caron, C. Braud, C. Bunel and M. Vert, Polymer, 1990, 31, 1797-1802.

147. C. Braud, C. Bunel, H. Garreau and M. Vert, Polym. Bull., 1983, 9, 198-203.

148. M. E. Martinez Barbosa, S. Cammas, M. Appel and G. Ponchel, Biomacromolecules, 2004, 5, 137-143.

149. P. Guerin, J. P. Girault, A. Caron, J. Francillette and M. Vert, Macromolecules, 1992, 25, 143-148.

150. I. Bajaj and R. Singhal, Bioresour. Technol., 2011, 102, 5551-5561.

151. G. Cavallaro, G. Pitarresi and G. Giammona, Curr. Top. Med. Chem., 2001, 11, 23822389. 
152. S. R. Leadley, M. C. Davies, M. Vert, C. Braud, A. J. Paul, A. G. Shard and J. F. Watts, Macromolecules, 1997, 30, 6920-6928.

153. Y. Zhang and R. W. Lenz, Makromol. Chem., Macromol. Symp., 1992, 60, 187-195.

154. M. Benvenuti and R. W. Lenz, J. Polym. Sci., Part A: Polym. Chem., 1991, 29, $793-$ 805.

155. B. He and M. B. Chan-Park, Macromolecules, 2005, 38, 8227-8234.

156. B. Nottelet, C. Di Tommaso, K. Mondon, R. Gurny and M. Möller, J. Polym. Sci., Part A: Polym. Chem., 2010, 48, 3244-3254.

157. B. He, Y. Wan, J. Bei and S. Wang, Biomaterials, 2004, 25, 5239-5247.

158. B. He, J. Bei and S. Wang, Polymer, 2003, 44, 989-994.

159. B. He, Y. F. Poon, J. Feng and M. B. Chan-Park, J. Biomed. Mater. Res., Part A, 2008, 87A, 254-263.

160. Y. Liu, W. Wang, J. Wang, Y. Wang, Z. Yuan, S. Tang, M. Liu and H. Tang, Colloids and Surfaces B: Biointerfaces, 2010, 75, 370-376.

161. L. Wang, X. Jia, X. Liu, Z. Yuan and J. Huang, Colloid. Polym. Sci., 2006, 285, $273-$ 281.

162. L. Wang, X. Jia, Y. Chen, Y. Che and Z. Yuan, J. Biomed. Mater. Res., Part A, 2008, 87, 459-469.

163. J. De Winter, O. Coulembier, P. Gerbaux and P. Dubois, Macromolecules, 2010, 43, 10291-10296.

164. Z. W. Huang, V. Laurent, G. Chetouani, J. Y. Ljubimova, E. Holler, T. Benvegnu, P. Loyer and S. Cammas-Marion, Int. J. Pharm., 2012, 423, 84-92.

165. P. Loyer, W. Bedhouche, Z. W. Huang and S. Cammas-Marion, Int. J. Pharm., 2013, 454, 727-737.

166. M. Helou, O. Miserque, J.-M. Brusson, J.-F. Carpentier and S. M. Guillaume, Adv. Synth. Catal., 2009, 351, 1312-1324.

167. M. Helou, O. Miserque, J.-M. Brusson, J.-F. Carpentier and S. M. Guillaume, Macromol. Rapid Commun., 2009, 30, 2128-2135.

168. M. Helou, O. Miserque, J.-M. Brusson, J.-F. Carpentier and S. M. Guillaume, Chem. Eur. J., 2008, 14, 8772-8775.

169. C. G. Jaffredo, Y. Chapurina, S. M. Guillaume and J.-F. Carpentier, Angew. Chem. Int. Ed., 2014, DOI: 10.1002/anie.201310523.

170. M. Vert, Macromol. Biosci., 2011, 11, 1653-1661.

171. M. Vert, P. Fournie, M. Bousta, D. Domurado, G. Phillipe, C. Braud and H. Holler, Macromolecular Reports, 1994, A31, 723-730.

172. E. Holler, in Handbook of Engineering Polymeric Materials, , ed. N. P. Cheremisinoff, 1997, pp. 93-103

173. T. Ouchi, in Frontier in Biomedical Polymer Applications, ed. R. M. Ottenbrite, 1998, vol. 1, pp. 185-200

174. I. Taniguchi and Y. Kimura, Biopolymers, 2001, 3b, 431-447.

175. B.-S. Lee, M. Vert and E. Holler, Biopolymers, 2002, 3a, 75-103.

176. H. Ding, J. Portilla-Arias, R. Patil, K. L. Black, J. Y. Ljubimova and E. Holler, Biomaterials, 2011, 32, 5269-5278.

177. H. Ding, G. Helguera, J. A. Rodríguez, J. Markman, R. Luria-Pérez, P. Gangalum, J. Portilla-Arias, S. Inoue, T. R. Daniels-Wells, K. Black, E. Holler, M. L. Penichet and J. Y. Ljubimova, J. Controlled Release, 2013, 171, 322. 